\title{
THE STRATIGRAPHY OF THE KINDERHOOK SERIES OF IOWA
}

BY

LOWELL ROBERT LAUDON 


\section{CONTENTS}

I. INTRODUCTION PAGE

General introduction - . . 339

Classification - -

Purpose of the investigation._- 340

Location of area-1-1 340

Previous work -_.-_-_- 342

Field methods _..- 343

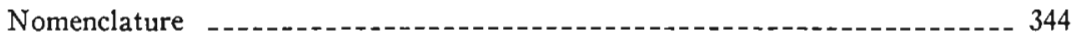

General introduction to the formations involved in the discussion.--_-_-_-- 344

The Cedar Valley limestone...... 344

The Shell Rock formation

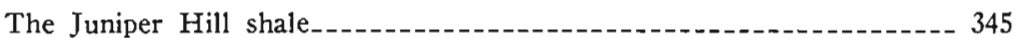

The Hackberry shale -

The Owen limestone.-_._._. 346

The Sheffield formation._-_._._._._._._._. 346

The Sweetland Creek beds._._._-_._. 346

The Maple Mill formation_._._. 346

The English River formation._-__-_- 347

The Hampton formation.-_-_-_- 347

The North Hill member._._._._._. 347

The Wassonville dolomite member._._. 347

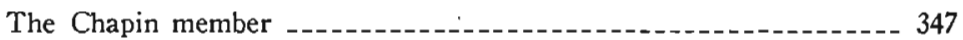

The Maynes Creek member._._. 347

The Eagle City member-_-_-_-_- 348

The Iowa Falls member._._. 348

The Burlington limestone

The Keokuk formation _._. 348

The Warsaw formation _._. 348

The Spergen formation _._. 348

The St. Louis limestone._-_. 349

The Ste. Genevieve formation. 349

Acknowledgments _.

II. Stratigraphy and Paleontology

Southeastern Iowa province

Introduction -

The Sweetland Creek beds._._. 352

Distribution and thickness......... 352

Stratigraphy -.._-_._- 354

Paleontology -

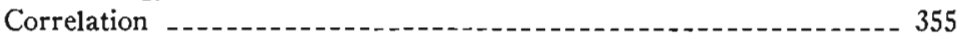

The Maple Mill formation._. 355

Distribution and thickness.......... 355

Lithologic character _._- 356

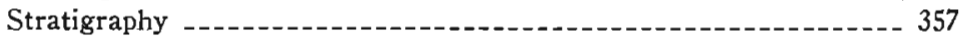


PAGE
Paleontology and correlation

Paleontology and correlation.... 357

The English River formation_._.

Distribution and thickness_-_-_- 359

Lithologic character .

Stratigraphy -_-_-_-_-_._- 361

Paleontology _-_-_-_._._- 361

English River at LeGrand_______- 364

Correlation -_-_- 365

The Hampton formation._-_-_-_- 366

The North Hill member._-_._- 366

Distribution and thickness..._. 366

Lithologic character -

Stratigraphy -_-_. 369

Paleontology and correlation._-_._- 370

The Wassonville member-_._-_._. 371

Distribution and thickness._._._. 371

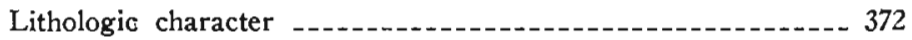

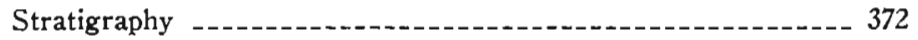

The English River-Hampton unconformity-_-_-_-_-_-_-_-_ 373

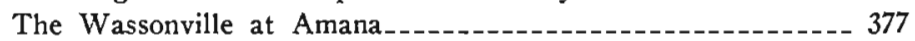

The English River of Marshall and Tama counties___-______- 378

Summary of the evidence supporting the English River-Hampton unconformity -...- 379

Paleontology and correlation.

Type sections in southeastern Iowa

The north-central Iowa province

Introduction _.-. 384

Distribution and thickness of Kinderhook

Lithologic character-_-_. 384

Structure - -

Divisions - -

General relations -

The Hampton formation._._._. 387

The Chapin member-_-_- 387

Distribution and thickness..... 389

Lithologic character -_-_-_- 391

Paleontology -_-_- 392

Stratigraphy --10 394

Correlations -

The Maynes Creek member... 395

Distribution and thickness._-_._- 396

Lithologic character -_-_-_-_-_-_-_-_-_-_-_-_-_-_-_ 397

Paleontology -

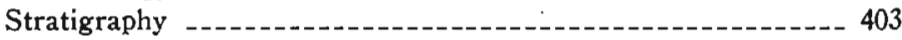

Correlation _._.

The Eagle City member-_._. 404

Distribution and thickness_._._._._._._._._. 404

Lithologic character _._-_._._._. 405

Paleontology _. 407 
PAGE

Stratigraphy _._- 411

Correlation -

The Iowa Falls member._______ 412

Distribution and thickness__._._._-_._- 413

Lithologic character -._._._. 413

Paleontology -

Stratigraphy _._._- 416

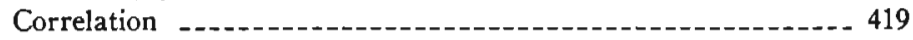

The Hampton formation at LeGrand._._-_._._. 419

Distribution and thickness._._. 422

Lithologic character -

Paleontology -

Stratigraphy -_-_-_-_-_- 430

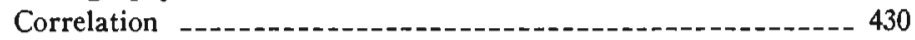

Type sections in north-central Iowa

Bibliography -...-. 434 


\section{LIST OF ILLUSTRATIONS}

45. Map showing the areal distribution of the Kinderhook series in Iowa and the two provinces of the Iowa Kinderhook

46. Composite Kinderhook section of southeastern Iowa

47. Maple Mill exposure on Smith creek, Louisa county

48. Exposure of English River strata at North Hill, Burlington_-_-_-_-_-_- 366

49. Hampton formation of the southeastern Iowa province._._. 367

50. Kinderhook correlation chart for southeastern Iowa

51. Composite section of the Sheffield formation

52. Mississippian section of north-central Iowa

53. Composite section of Chapin and Maynes Creek members_-_-_-_._. 390

54. Maynes Creek member at Hampton_._..._. 395

55. Composite section of the Eagle City and Iowa Falls members._-_._-_._. 406

56. Ellsworth stone quarry at Iowa Falls._. 410

57. Uneven contact of Eagle City member with the Iowa Falls member-_._-_ 411

58. Contact of the Eagle City with the Iowa Falls_______._._. 416

59. Type section of the Gilmore City beds_________ 417

60. Alden limestone west of Iowa Falls on Iowa river

61. Alden limestone in the quarry of the Iowa Limestone Company at Alden_- 418

62. Composite section of the LeGrand beds showing life zones.......... 423

63. Kinderhook correlation chart for Iowa

64. A real gealogy map of Franklin county _-____- 438

65. Areal geology map of Hardin county _-_._- 439

66. Areal geology map of Butler county _............. 440

67. Areal geology map of Marshall county _._. 441

68. Areal geology map of Tama county _._. 442 


\section{THE KINDERHOOK SERIES' OF IOWA INTRODUCTION}

The Mississippian of Iowa is represented only by four series of formations. Three series of these Mississippian formations, the Kinderhook, the Osage and the Meramec, are well developed in the state while the Chester series is represented by only a single formation. Of these four series this paper deals particularly with the oldest or the Kinderhook.

The Mississippian of Iowa is of marine origin with limestone predominating. Dolomites, shales and sandstones are present but are of lesser importance. The Mississippian limestones are particularly noted for the great amount of chert which they usually contain. These marine sedimentary beds are almost without exception fossiliferous and usually carry a very prolific fauna.

The regional dip of the sedimentary strata in Iowa is to the southwest at a slope of about 12 feet to the mile. This dip brings the Mississippian rocks to the surface in a narrow belt extending across the state in a northwest-southeast direction. This belt of outcrop reaches from Keokuk on the southeast to Humboldt county in the northern central part of the state. The Mississippian strata are covered by younger formations to the west of Humboldt county.

\section{Classification}

The rocks that are now known as Mississippian were classed under various names, such as "Carboniferous," "Lower Carboniferous" and "Sub-Carboniferous," for a period of 70 years. This period lasted from 1821, when Thomas Nuttall" compared the "Encrinital group at Burlington" with the Mountain Limestone of Europe, until 1891 when $\mathrm{H}$. S. Williams ${ }^{2}$ proposed the term Mississippian for them.

In 1839 D. D. Owen introduced the term Sub-Carboniferous for the strata underlying the "Coal Measures" and overlying the Hamilton. M. DeVerneuil in 1847 recognized the fact that the Waverly group of Ohio definitely belonged with the Carboniferous. The St. Louis lime-

1 Nuttall, T., Observations on Geological Structure of the Valley of the Mississippi: Jour.

Acad. Nat. Sci. Philadelphia. Vol. II, pp. 14-52, 1821. p. 135,1891 . 
stone was named by $\mathrm{H}$. King in 1851 . The final report of D. D. Owen on the geology of Iowa, Minnesota, and Wisconsin was published in 1852. In this report the Sub-Carboniferous was divided into a lower and an upper series. The division between these two series was at the base of the geodiferous bed or the center of what is now the Warsaw formation.

In 1853 Swallow correlated the Chouteau limestone, the Vermicular sandstone and the Lithographic limestone with the Chemung of New York. James Hall, working in Iowa in a period from 1856 to 1859 , also referred these beds to the Chemung. In the same period. Hall proposed the term Burlington for the "Encrinital group" of Owen and also cleared up the use of the term Keokuk. In $1860 \mathrm{C}$. A. White questioned the correlation of these beds with the Chemung, calling attention to the fact that the faunas were much like those of the overlying Sub-Carboniferous beds. Later in the same year, however, White and Whitfield recognized the "Chemung" of the Mississippi valley. It was in 1861 that Meek and Worthen realized that these beds were distinctly younger than the Chemung of New York and proposed the name Kinderhook for them. The Kinderhook of Meek and Worthen included only the Lithographic limestone (Louisiana), the Vermicular sandstone (Hannibal) and the Chouteau limestone. In 1874 C. C. Broadhead proposed the term "Chouteau Group" for the members included in the Kinderhook of Meek and Worthen. This term was not used, however, because the term Kinderhook held priority.

The Kinderhook has since been modified by Weller, Van Tuyl, and Moore to include certain of the shale beds below the Louisiana limestone and overlying the Devonian limestones.

\section{Purpose of the Investigation}

This investigation has been carried on with these points in viewto determine the stratigraphic relations of the Kinderhook strata within the series itself and with the overlying and underlying formations; to establish definite life zones that may be traced throughout the region; and to make correlations with adjacent regions based on the stratigraphy and paleontology.

\section{Location of Area}

The belt of 'outcrop of the Kinderhook of Iowa reaches roughly from Fort Madison on the southeast to the northern part of Franklin 
TABLE I

Classification of the Mississippian Formations of the Mississippi Valley

\begin{tabular}{|c|c|c|}
\hline SysteM & SERIES & FORMATION \\
\hline \multirow{6}{*}{ Mississippian } & Upper Chester & $\begin{array}{l}\text { Kinkaid } \\
\text { Degonia } \\
\text { Clore } \\
\text { Palestine } \\
\text { Menard } \\
\text { Waltersburg } \\
\text { Vienna } \\
\text { Tar Springs }\end{array}$ \\
\hline & Middle Chester & $\begin{array}{l}\text { Glen Dean } \\
\text { Hardinsburg } \\
\text { Golconda } \\
\text { Cypress }\end{array}$ \\
\hline & Lower Chester & $\begin{array}{l}\text { Paint Creek } \\
\text { Yankeetown } \\
\text { Renault } \\
\text { Aux Vases } \\
\text { Ste. Genevieve }\end{array}$ \\
\hline & Meramec & $\begin{array}{l}\text { St. Louis } \\
\text { Spergen }\end{array}$ \\
\hline & Usage & $\begin{array}{l}\text { Warsaw } \\
\text { Keokuk } \\
\text { Burlington } \\
\text { Fern Glen }\end{array}$ \\
\hline & Kinderhook & $\begin{array}{l}\text { Chouteau } \\
\text { Hannibal } \\
\text { Louisiana } \\
\text { Chattanooga }\end{array}$ \\
\hline
\end{tabular}

county in north-central Iowa. This area of outcrop of the Kinderhook strata will be divided in this paper roughly into two provinces. The southeastern Iowa province will include all Kinderhook strata

TABLE II

General Classification of the Mississippian of Iorea

\begin{tabular}{l|l|l}
\hline \hline \multicolumn{1}{c|}{ System } & \multicolumn{1}{c}{ Series } & \multicolumn{1}{c}{ Formation } \\
\hline Chester & Pella \\
\hline Meramec & $\begin{array}{l}\text { St. Louis } \\
\text { Spergen }\end{array}$ \\
\cline { 1 - 2 } & $\begin{array}{l}\text { Warsaw } \\
\text { Keokuk } \\
\text { Burlington }\end{array}$ \\
\hline Osage & $\begin{array}{l}\text { Hampton } \\
\text { English River } \\
\text { Maple Mill }\end{array}$ \\
\hline
\end{tabular}


exposed in Des Moines, Louisa, Washington, Johnson and Iowa counties. The north-central Iowa province includes the Kinderhook of Tama, Marshall, Grundy, Hardin, Butler and Franklin counties. The section of Kinderhook strata exposed along Iowa river near LeGrand is located within the limits of the north-central Iowa province. However, these exposures are approximately midway between the best development of the Kinderhook in southeastern Iowa and the best development of the Kinderhook in north-central Iowa, so a special chapter will be devoted to the discussion of the LeGrand section.

\section{Previous Work}

The early work on the Kinderhook of Iowa has been partly reviewed in the history of the classification of the Mississippian. The work of Meek and Worthen while they were connected with the Illinois State Survey cannot be underestimated. Meek and Worthen, Hall, White, Swallow, Miller and Gurley, Shumard, and Winchell all figured very prominently in the description of Kinderhook fossils. More recently Charles Wachsmuth and Frank Springer, Stuart Weller, and R. C. Moore have described many species from the Kinderhook beds.

The county survey reports of Charles $R$. Keyes for Des Moines county, J. A. Udden for Louisa county, Samuel Calvin for Johnson county, S. W. Stookey for Iowa county, H. F. Bain for Washington county, T. E. Savage for Tama county, S. W. Beyer for Hardin and Marshall counties, M. F. Arey for Grundy and Butler counties, and I. A. Williams for Franklin county were all used very extensively.

The Kinderhook faunal studies of Stuart Weller from 1899 to 1906 have proven to be very valuable. Monograph I of the Illinois State Survey (Mississippian Brachiopoda) must also be mentioned.

F. M. Van Tuyl spent a series of summers studying the Mississippian of Iowa. The results of this field work were published in volume $\mathrm{XXX}$ of the Iowa Geological Survey. This report on "The Stratigraphy of the Mississippian Formations of Iowa" has been a constant reference book.

In 1928 the Missouri Bureau of Geology and Mines published a report on the "Early Mississippian Formations of Missouri" by R. C. Moore. This report forms a basis for many of the correlations made in this paper. 


\section{Field Methods}

The field work upon which this report is based was carried on during the summer field seasons of 1928 and 1929. An attempt was made during this time to see every exposure of the Kinderhook within the state. These exposures have been mapped over a considerable part of the north-central Iowa province.

A great deal of the correlation has been done by zone stratigraphy. A zone is established by a combination of several factors. The association of species within a limited vertical distance is an important factor. The abundance of certain species and the scarcity of others is used very advantageously. The lithology of the beds often helps greatly in the establishment of a zone. Relatively barren horizons often form natural breaks between the zones. A combination of all of these factors will usually establish a zone that may be traced over considerable distances. During this work definite zones have been established within each of the members.

In this report positions within sections are located in the following manner. The section in which the position is to be located is divided into nine equal rectangles. These rectangles are numbered from left to right up to nine: The point to be located would then lie within one of these rectangles. This one would again be divided into nine equal rectangles and numbered accordingly. The position would then be within one of these smaller rectangles. If the position should lie within the seventh small rectangle of the fifth large rectangle its position would be 57 . The small rectangle could be divided again and even a fourth time if the location of the point should demand such accuracy.

The position of the point in the diagram would

\begin{tabular}{|c|c|c|}
\hline 1 & 2 & 3 \\
\hline 4 & 5 & 6 \\
\hline$y$ & 8 & 9 \\
\hline
\end{tabular}
be 78 of section -, R. - W., Twp. - N. If the smaller rectangle should again be, divided into nine rectangles the position of the point would be 785 of section -, R. - W., Twp. - N.

A topographic base map was not available for the region and locations were made with the aid of county maps furnished by the State Highway Department. During the early part of the investigation the areal geology maps of the county survey reports were used extensively. 


\section{Nomenclature}

The term Hampton is proposed for the Kinderhook beds of Iowa that lie stratigraphically above the English River formation and below the oldest beds of the Osage series. This formation is named for Hampton, the county seat of Franklin county, around which town this formation is best exposed.

The term North Hill is proposed for the oldest member of the Hampton formation in the southeastern Iowa province. This member includes all Kinderhook strata stratigraphically above the English River formation and below the brown dolomites of the. Wassonville member of the Hampton formation. It is named for the exposure on North Hill in the city of Burlington, where the member with both its upper and lower contacts is exposed.

The term Kinderhook is used as a series name in this report and the terms Maple Mill, English River and Hampton are considered as formation names. If further classification is necessary the formations are divided into members and the members into zones.

The Hampton formation is divided in north-central Iowa into four members. The names Chapin, Maynes Creek, Eagle City and Iowa Falls were introduced by Van Tuyl in 1922 for these members and are retained in this report essentially as defined by Van Tuyl except for some slight changes in their contacts.

\section{General Introduction to the Formations. Involved in the Discussion}

S. E. P.-Southeastern Province

N. C. P.-North-Central Province

The Cedar Valley limestone, S. E. P.-The Cedar Valley limestone unconformably underlies the Sweetland Creek beds of the southeastern province. It also underlies the Sheffield formation in the southeastern part of the north-central province. At other places in the north-central province it underlies different formations of the Lime Creek series. Lithologically it consists of hard gray fossiliferous limestone ledges and brown shaly dolomite. It is Upper Devonian in age.

The Shell Rock formation, N. C. P.-The Shell Rock formation unconformably overlies the Cedar Valley limestone and in the northern part of the north-central province is unconformably overlain by the Juniper Hill shale. In the southern part of the north-central province 


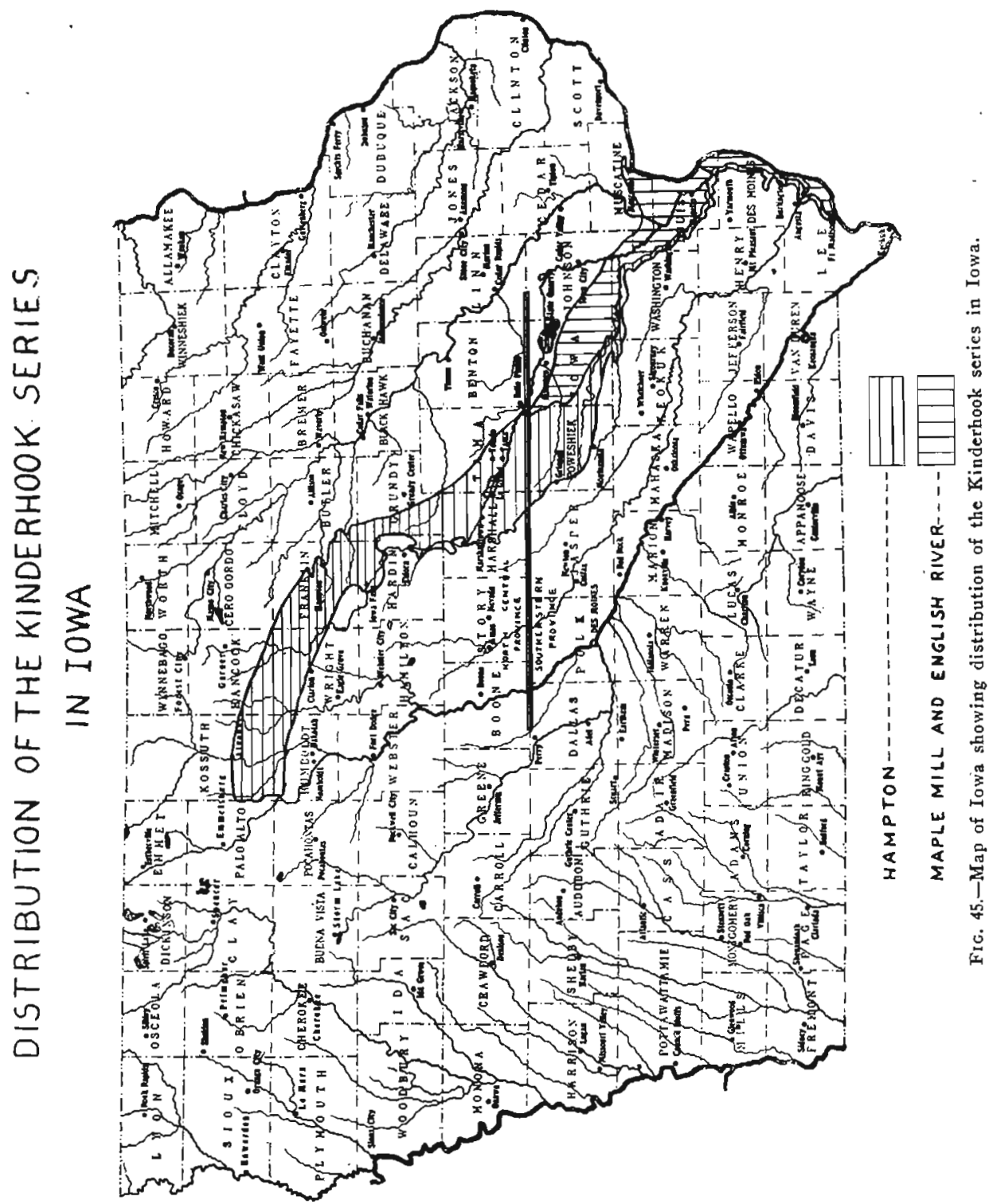

it is undoubtedly directly overlain by the Sheffield formation. It consists of hard gray fossiliferous limestone and dolomite and is Upper Devonian in age.

The Juniper Hill shale, N. C. P.-The Juniper Hill shale unconformably overlies the Shell Rock formation and conformably underlies 
the Hackberry shale. At some places in the north-central province the Juniper Hill shale is undoubtedly directly overlain by the Sheffield formation. The Juniper Hill consists of soft blue fissile shale and also is Upper Devonian in age.

The Hackberry shale, N.C.P.-The Hackberry shale conformably overlies the Juniper Hill and is conformably overlain by the Owen limestone. At a few places it is probably unconformably overlain by. the Sheffield formation. This relation is not exposed, however. The Hackberry consists of gray soft exceptionally fossiliferous highly calcareous shales and is Upper Devonian in age.

The Owen limestone, N.C. P.-The Owen conformably overlies the Hackberry formation and unconformably underlies the Sheffield formation. It consists of hard gray to blue fossiliferous limestone ledges interbedded with soft yellow fossiliferous dolomite and some shale. The Owen marks the upper limit of the Lime Creek series and is Upper Devonian in age.

The Sheffield formation, N.C.P. and S. E. P.-The Sheffield formation unconformably overlies the Lime Creek series in the northcentral province and unconformably overlies the Cedar Valley limestone in the southeastern province. It is unconformably overlain by the Maple Mill and English River formations in the southeastern province and by the Hampton formation in the north-central province. It is about 125 feet in thickness and consists of blue soft unctuous shale interbedded with brown dolomite. Locally in the upper part some limestone and chert may be seen. Faunally it is very similar to the Chemung of New York, which makes it Upper Devonian in age.

The Sweetland Creek beds, S. E. P.-The Sweetland Creek beds unconformably overlie the Cedar Valley limestone and are unconformably overlain by Pennsylvanian shales in their area of exposure. They consist of greenish blue shales interbedded with blue dolomitic shale. They are very poorly fossiliferous and are probably to be correlated with some part of the Maple Mill formation.

The Maple Mill formation, S. E. P. - The Maple Mill contact with the Cedar Valley is not exposed. It probably overlaps unconformably on to the Cedar Valley limestone. It is conformably overlain by the English River formation. Lithologically it consists of soft blue to 
gray unctuous pyritic shale. It. contains very few fossils but should probably be correlated with the Chattanooga shales.

The English River formation, S. E. P. and N. C. P.-The English River formation conformably overlies the Maple- Mill formation and unconformably underlies the Hampton formation. It consists of blue massive siltstone ledges that are filled with casts of fossils. It is correlated with the Hannibal shale of Missouri.

The Hampton formation, S. E. P. and N.C.P.-This formation includes the six following members:

The North Hill member, S. E. P.-The North Hill member lies unconformably over the English River formation. At a few places in the southeastern province it rests possibly on the Maple Mill formation. It is conformably overlain by the Wassonville member of the Hampton formation. Lithologically it consists of semilithographic limestone, quartz siltstone and oölitic limestone. It is correlated with the Chapin member of the Hampton formation in the north-central province and with some portion of the Chouteau of Missouri.

The Wassonville dolomite member, S. E. P.-This member conformably overlies the North Hill member in some parts of the province and unconformably overlies the English River, Maple Mill and Sheffield formations in other parts of the southeastern province. It consists of massive brown dolomite ledges interbedded with white very fossiliferous chert. It is correlated with the Maynes Creek member of the Hampton formation of the north-central province and with some portion of the Chouteau of Missouri.

The Chapin member, N.C. P.-The Chapin member lies unconformably over the Sheffield formation and conformably under the Maynes Creek member of the Hampton formation. It consists of hard gray thin-bedded limestone and oölitic limestone. It is correlated with the North Hill member of the southeastern province and with some portion of the Chouteau of Missouri.

The Maynes Creek member, N. C. P.-The Maynes Creek member conformably overlies the Chapin member and conformably underlies the Eagle City member of the Hampton formation. It consists of massive brown fossiliferous dolomite interbedded with white exceptionally fossiliferous chert. It is correlated with the Wassonville mem- 
ber of the southeastern province and is closely related to the Chouteau of Missouri.

The Eagle City member, N. C. P.-The Eagle City member conformably overlies the Maynes Creek member and conformably underlies the Iowa Falls member of the Hampton formation. It consists of brown and gray limestone in the base, dolomite in the central part, and lithographic and oölitic limestone at the top. Faunally it resembles the Chouteau of Missouri. The Eagle City probably is younger than any portion of the Chouteau, but it has a fauna that was derived directly from that of the Chouteau.

The Iowa Falls member, N. C. P.-The Iowa Falls member conformably overlies the Eagle City member of the Hampton formation and is unconformably overlain by the Alden limestone. It consists entirely of brown dolomite ledges which for the most part are very poorly fossiliferous. It probably is younger than any portion of the Chouteau of Missouri, but it has a fauna that was derived directly from the Chouteau fauna, and it should therefore be considered a part of the Hampton formation of Iowa.

The Burlington formation, S. E. P.-The Burlington limestone unconformably overlies the Hampton formation and conformably underlies the Keokuk limestone. It consists of massive brown crinoidal limestone in the base, brown dolomite interbedded with much chert in the central portion, and gray and green limestones interbedded with chert in the upper portion. It is correlated with the Burlington of Missouri.

The Keokuk formation, S. E. P.-The Keokuk limestone conformably overlies the Burlington limestone and grades conformably into the Warsaw formation. It consists in the basal part of soft yellow dolomite interbedded with much chert and of massive blue shaly fossiliferous limestone beds in the top. It is correlated with the Keokuk beds of Missouri and Indiana.

The Warsaze formation, S. E. P.-The Warsaw formation lies conformably over the Keokuk limestone and is unconformably overlain by the Spergen formation. It consists in the lower portion of soft black and gray fissile shale filled with geodes and in the upper part of blue massive limestone interbedded with shale and dolomite.

The Spergen Formation S. E. P. and N. C. P.-The Spergen of the S. E. P. unconformably overlies the Warsaw formation and un- 
conformably underlies the St. Louis limestone. It consists of brown dolomitic limestone beds and is correlated with the Spergen of Indiana.

It is questionable whether the Spergen is present in the N. C. P. The Alden limestone of Hardin county and the Gilmore City limestone of Humboldt and Pocahontas counties suggest Spergen both lithologically and faunally: The large crinoid fauna in the base of the Gilmore City limestone carries a large number of Kinderhook genera. The Alden limestone, which is correlated with the Gilmore City limestone in this paper, lies unconformably on the upper surface of the Iowa Falls member of the Hampton formation. This relation seems to suggest that they should not be considered to be Kinderhook in age.

The St. Louis limestone, S. E. P. and N. C. P.-The St. Louis limestone unconformably overlies the Spergen formation and may be seen resting unconformably on several other Mississippian formations. It is conformably overlain by the Ste. Genevieve formation., Lithologically it consists of peculiar wavy beds of blue to gray limestones that are usually strongly brecciated. These limestone ledges are interbedded with shale and dolomite.

The Ste. Genevievie formation, S. E: P. and N. C. P.-The Ste. Genevieve unconformably overlies the St. Louis limestone and is unconformably overlain by beds of Pennsylvanian age. It consists of gray, blue, green, black and reddish shales that are very fossiliferous in their upper part. The formation is correlated with the Ste. Genevieve of Missouri.

\section{Acknowledgments}

The writer is most indebted to Dr. A. O. Thomas of the University of Iowa, whose careful guidance both in the field and in the laboratory has greatly aided in the production of this paper. Large collections of fossils made by Doctor Thomas throughout the region were turned over to the writer.

Dr. A. C. Tester of the University of Iowa has given valuable aid during the study of the sedimentation and also with regard to the early Mississippian stratigraphy.

Dr. A. C. Trowbridge of the University of Iowa has given valuable aid in the stratigraphy along Mississippi river.

Thanks are given to Dr. Louise Fillman of Simpson College for the use of extensive collections of fossils from the Wassonville cherts. 
Thanks must be given to Mr. B. H. Beane of LeGrand, Iowa, whose long field experience and extensive collections were made available.

Mr. C. L. Cooper of the Oklahoma Geological Survey has given valuable aid in the early Mississippian stratigraphy.

Dr. James S. Williams of the University of Missouri must be thanked for aid in the stratigraphy of the Kinderhook. 


\section{STRATIGRAPHY AND PALEONTOLOGY}

\section{Southeastern Iowa Province}

\section{INTRODUCTION}

The basal formations of the Kinderhook are confined, with the exception of one small group of exposures in Marshall and Tama counties, to the southeastern Iowa province. The Maple Mill shale formation is not exposed northwest of Washington county. The most northwesterly exposures of the English River formation are found along Iowa river in Marshall and Tama counties.

The Hampton formation is much less developed in the southeastern Iowa province than in the north-central province. Only the two basal members of this formation are exposed in southeastern Iowa.

The basal Kinderhook shale beds have been referred by different writers to the Upper Devonian and to the basal Mississippian. The exact age of these shale beds that occupy the interval between definitely recognized Devonian and definitely recognized Mississippian horizons has long been a disputed question. If the Devonian grades conformably into the Mississippian it is obviously an arbitrary matter as to where the line separating the two is placed.

Lithological changes in beds and changes in faunas are usually inaugurated by some diastrophic movement which changes the conditions of sedimentation and the environment in which the faunas live. If such a diastrophic movement is slow and gentle we cannot expect abrupt changes or marked unconformities at places where sedimentation is in progress when the movement is inaugurated.

It is not possible to draw this line on paleontology alone. The Upper Devonian limestones are characterized by a very abundant fauna. In Chemung time this abundant fauna slowly dwindled until only a very few species were left in the uppermost beds of Chemung age. Following the deposition of the Chemung there was a long period during which life in the continental basins was not abundant. This transition period is represented by such formations as the Chattanooga shale, the Sweetland Creek shale, the Maple Mill shale and the Grassy Creek shale. At the time of the deposition of the Saverton shale, the Louisiana limestone and the Hannibal shale conditions are again 
favorable for life. The faunas represented in these formations are definitely Mississippian but retain many of the old Devonian genera. The presence of the new fauna, however, determines the age of the beds.

It is obvious that lithology cannot be used alone to establish such a contact. In both Iowa and New York the Upper Devonian shales are very much like the shales that are found in the beds in question. In Missouri the first beds that may be definitely referred to the Mississippian are also shales with like characteristics.

The distribution of these shales should help materially in the matter of their classification. The shales of Chemung age usually directly overlie beds of known Deyonian age while the shales in question bear very little relation to the Upper Devonian. These shales spread far and wide over the country and rest on older formations of almost every age. They are found in New York, Ohio, Indiana, Michigan, Illinois, Iowa, Missouri, Tennessee, Kentucky, Arkansas and Oklahoma. These shales are more often overlain by Mississippian strata than underlain by Devonian strata. From this distributional relation it seems likely that the greatest change of conditions took place before their deposition and that they should therefore be assigned an early Mississippian age.

Perhaps the best proof for the Mississippian age of the basal Kinderhook shale beds of Iowa and Missouri is found in the great unconformity that lies between them and the Sheffield formation of Chemung age. This unconformity bevels all of the Sheffield formation, all of the Lime Creek series, all of the Cedar Valley limestone, all of the Niagaran dolomite, and a portion of the Ordovician sediments. In northeastern Missouri the basal part of the Kinderhook shale series is found resting on the Galena limestone.

\section{THE SWEETLAND CREEK BEDS}

In 1922 Van Tuyl ${ }^{3}$ placed the Sweetland Creek beds in the lower portion of the Kinderhook. They will be considered in this report as belonging to the Kinderhook.

Distribution and Thickness. - The exposures of the Sweetland Creek beds are confined to the lower part of the bluffs on the north side of Mississippi river east of the city of Muscatine in Muscatine county.

a Van Tuyl, Iowa Geol. Survey, Vol. XXX, p. 71, 1922. 


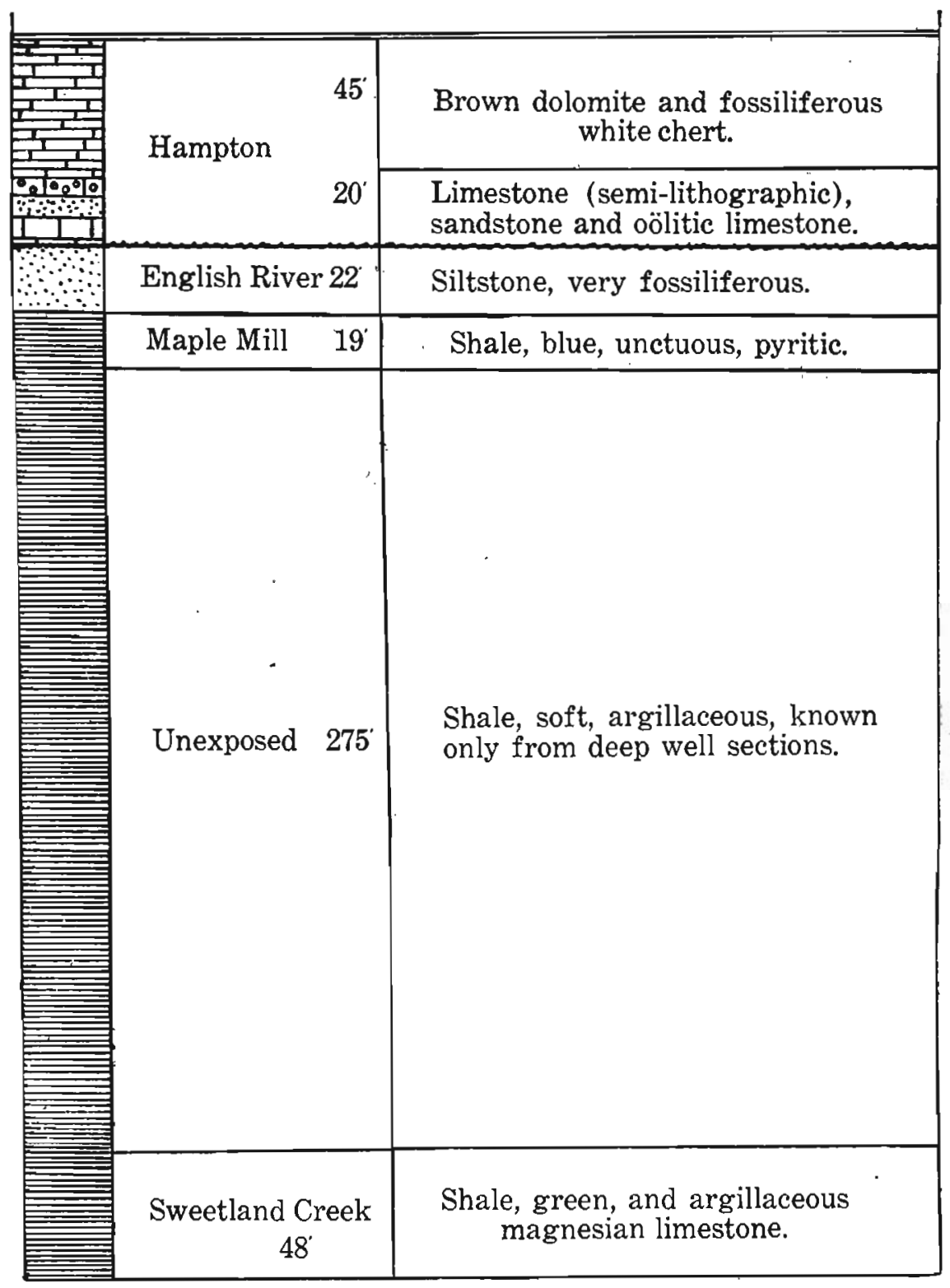

Fig. 46-Composite section of the Kinderhook of Southeastern Iowa.

The exposures are mainly limited to the walls of the creeks that cut the Mississippi bluffs at this locality. The best exposures are located within five miles of the city of Muscatine. Farther to the east the 
Sweetland Creek is represented only by discontinuous beds and is often cut out entirely by the "coal measures". The type exposure is located on Sweetland creek about five miles east of the city of Muscatine at 37 of section 27, Sweetland township. It is also well exposed in the valleys of each of the three creeks immediately to the west of Sweetland creek.

A complete section of the Sweetland Creek may not be seen at any one place. At the type section about 20 feet is exposed, which represents only the basal part of the complete section. The uppermost bed of dark shales is almost entirely missing at this place. Van Tuyl places the maximum thickness at 48 feet.

Stratigraphy.-The Sweetland Creek may be seen at several localities in disconformable contact with the underlying Cedar Valley limestone of Upper Devonian age. In the region of its exposure it may also be seen in disconformable contact with the overlying shales of Pennsylvanian age.

South of the area in which the Sweetland Creek is exposed, namely in Des Moines and Lee counties, a blue shale bed underlies the English River gritstone. At the city of Burlington the thickness of this shale bed has been determined through deep well sections to be 375 feet. Only the upper part of this shale bed is exposed in Iowa.

The unconformity at the top of the Cedar Valley limestone becomes more marked toward the south. In Clark county in northeastern Missouri erosion has removed both the Devonian and Silurian beds so that the Kinderhook shale rests unconformably on the Maquoketa shale." If the Kinderhook shale overlaps on to an unconformable surface it is likely that the Sweetland Creek beds do not represent the basal part of the formation.

Paleontology.-The fauna of the Sweetland Creek is very meager and very poorly preserved. The list given by Udden ${ }^{5}$ is as follows :

\footnotetext{
Lingula subspatulata $M$. and W.

Lingula cf. nuda Hall

Lingula cf. melie Hall

Lingula sp.

Gastropod sp.

Spathiocaris emersoni Clarke

Solenocaris strigata Meek?

Ptyctodus calceolus N. and W.

Rhynchodus cf. excavatus Newb. Synthetodus sp.
} 
In the lower three inches of the formation just above its unconformable contact with the Cedar Valley limestone may be found a fish tooth conglomerate. The teeth, which are usually very much fragmented, are scattered through this lower hard green dolomitic shale bed. Fish tooth conglomerates of this nature just above unconformable contacts probably originate where the waves break these fish to pieces along the shorelines.

The fish tooth conglomerate is followed by about two and one-half feet of softer green dolomitic shale that is almost unfossiliferous. One layer contains an occasional fish tooth and a few plant remains.

About three feet above the contact of the Cedar Valley limestone is found a hard bluish green dolomite that contains a few indistinct casts of brachiopods. A few specimens of Lingula were obtained, also one cast that has been referred to the genus Reticularia and one specimen that resembles the brachial valve of a Schizophoria. Plant impressions occur at several horizons. This dolomitic horizon is not over two feet in thickness.

Above the dolomite ledge may be seen about eight feet of greenish shales interbedded with darker material. Pyrite and hard green concretions are scattered throughout the mass. The horizon is unfossiliferous except for occasional indistinct plant impressions.

The upper portion of the Sweetland Creek consists of dark bituminous shales filled with pyrite. In the lower part of this zone, which is about 32 feet in thickness, are lenses of blue shale. These lower layers carry the specimens of Spathiocaris and Solenocaris.

Correlation.-There is very little fauna in the Sweetland Creek to help one in correlation. The presence of Spathiocaris and Solenocaris would suggest that it be correlated with some part of the Chattanooga shale.

\section{THE MAPLE MILL FORMATION}

The Maple Mill shale is exposed only in the southeastern province. Its complete section of 370 feet is known only from deep well sections. The maximum exposed section of the Maple Mill formation is only 60 feet. The Maple Mill is defined as including everything below the English River gritstone and above the Devonian formations.

Distribution and Thickness.-Because of the soft nature of the formation its exposures are practically limited to the base of the Kinderhook-Osage escarpment that forms the common bluff of Mississippi 
and Iowa rivers. A line of exposures of the Maple Mill may be traced northward from Burlington along the base of the Mississippi bluff. A few miles north of the city the formation dips beneath the level of the flood plain and is not exposed again until the lower valley of Smith creek in Louisa county is reached. Thence it is exposed in several places along the south bluff of Iowa river in Louisa county: These exposures are particularly available for study in the basin of Long creek to the south of Columbus Junction.

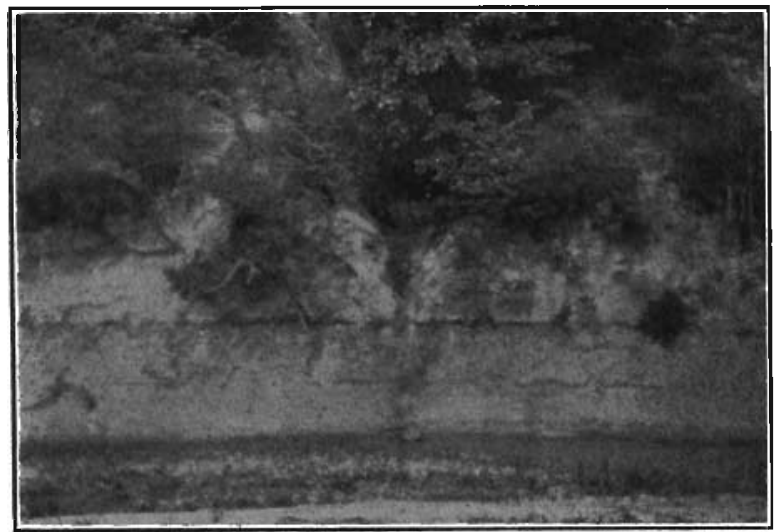

Fig. 47.-Maple Mill exposure on Smith creek, Louisa county.

The Maple Mill is not exposed again until the valley of English river in Washington county is reached. Here exposures are found in the bluffs of the river for a considerable distance on either side of the town of Kalona. The best exposures may be seen in the old clay pits one mile south of Kalona.

The Maple Mill is thought to immediately underlie the drift for a considerable distance to the west of Washington county, but it may be studied only through deep well sections which penetrate it. It is thought to underlie the greater part of southeastern Iowa. However, only the upper 60 feet is exposed in the maximum section at Burlington. All other known exposures are of a much smaller nature, few of them exceeding 15 'feet.

In well sections the ovetlying English River formation is not distinguished from the Maple Mill shale. The following thicknesses represent both the English River and the Maple Mill. At Burlington the thickness is 370 feet, at Fort Madison 268 feet, at Keokuk 225 
feet, at Winfield 325 feet, at Morning Sun 280 feet, at Fairfield 250 feet, at Sigourney 198 feet, at Ottumwa 165 feet, at Pella 125 feet, at Grinnell 180 feet, and at Marshalltown 145 feet.

It becomes very evident when one studies the distribution of the Sheffield formation in Iowa that much of the shale listed in these well sections very likely belongs to this formation. It is difficult to discriminate between these two shale bodies in well sections, but the Sheffield formation contains a large proportion of dolomitic and calcareous material that is not found in the Kinderhook shales. Much of the material penetrated in well sections in the central part of the state certainly belongs to the Sheffield formation.

Lithologic Character. - Lithologically the Maple Mill is a blue to gray to greenish very soft, unctuous shale. The blue color is by far the most predominating. The shale is usually filled with masses of pyrite and in many localities carries smaller quantities of sphalerite. Locally small calcareous lenses are found but nowhere in such quantities that they might be mistaken for limestone. There are occasional layers of black carbonaceous material. The Maple Mill grades into the overlying English River gritstone, which consists of small white crystalline grains of quartz.

Stratigraphy. -The Maple Mill formation overlies the Devonian limestones unconformably. This unconformable contact is not exposed in the region south of Sweetland creek. The Maple Mill formation probably overlaps on to the unconformable surface, thereby making the Sweetland Creek beds equivalent to some part of the Maple Mill which lies a considerable distance up from its base. The deepest part of the trough in which these shales were deposited probably was somewhere in the vicinity of Burlington, where these shales reach their maximum thickness.

Westward from Mississippi river the Maple Mill formation probably overlaps on to the Sheffield formation. This relation between the two shale beds has never been seen in the field, but from a study of the distribution of these two shale formations such a relation seems inevitable. The English River formation overlaps on to the Sheffield formation and is exposed in this relation at LeGrand.

The Maple Mill grades into the overlying English River gritstone with very little break in lithology at most places. The only evidence of a break between these two formations is found in the English 
river basin in Washington county, where the lithology changes abruptly from a blue shale filled with carbonaceous material to the fine blue quartz silts of the English River. This contact is exposed in the abandoned clay pit one mile south of Kalona on the south bluff of English river. The English River formation has been considered to be the fossiliferous top siliceous zone of the Maple Mill shale.

Paleontology and correlation.-The fauna of the Maple Mill is very meager and lends very little aid in correlation. Practically the only fossi! list known is the one given by Weller. The fossils on which this list is based were collected by Samuel Calvin and J. A. Udden in the clay pit of the Granite Brick Company at Burlington. The ledges from which this fauna was taken are not now exposed.

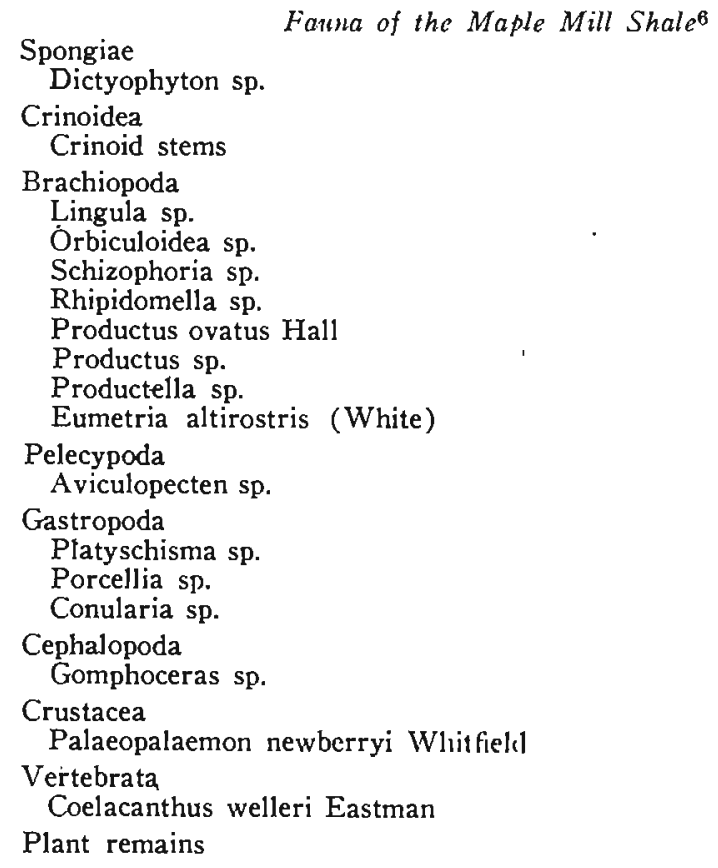

A large number of fish remains have been taken from the Maple Mill shale in the vicinity of Burlington. These fish remains were collected by Frank Springer.

Vertebrate Fauna of the Maple Mill Shabei

Pristicladodus springeri St. J. and W.

P. armatus St. J. and W.

Cladodus alternatus St. J. and W.

6 Van Tuyl, Iowa Geol. Survey, Vol. XXX, p. 55, 1922.

7 Moore, R. C., Missouri Bur. of Geol. and Mines, Vol. 21, Second Series, p. 31, 1928. 
Cladodus exiguus St. J. and W.

$C$. exilis St. J. and $W$.

Mesodmodus exsculptus St. J. and W.

$M$. explanatus St. J. and W.

Orodus daedalus St J. and W.

$O$. decussatus St. J. and W.

Pristodus ? acuminatus St. J. and W

Psephodus reticulatus St. J. and W.

Coelancanthus welleri Eastman"

Ctenacanthus sculptus St. J. and W.

C. speciosus St. J. and W.

Acondylacanthus gracilis St. J. and W.

Asteroptychius vetustus St. J. and $W$.

Physonemus depressus St. J. and W.

P. proclivus St. J. and W.

There is very little in these faunas that will help in correlation. Seven of the eighteen species of fishes present in the Maple Mill shale are found again in the sandstone zone of the North Hill member of the Hampton formation. The presence of Productella and Rhipidomella is slightly suggestive of the Saverton and Louisiana formations of Missouri.

In northeastern Missouri the Louisiana limestone is overlain by the Hannibal shale, which is about 100 feet thick, and is underlain by the Saverton shale, which is approximately 90 feet thick at its type sec- tion. The Louisiana limestone thins both to the north and south of its type area. It is missing entirely in the well sections in Iowa. The Louisiana limestone, then, is a lens-shaped mass of limestone in this large shale body.

The Hannibal shale of Missouri carries in its upper ledges a fauna that has been correlated with the English River of Iowa. This English River-Hannibal fauna marks one of the definite horizons of the Kinderhook. It is very easily separated from any other fauna of the Kinderhook and occupies a very limited stratigraphic position.

The English River formation of Iowa directly overlies the Maple Mill shale. From this relation it would seem likely that the upper portion of the Maple Mill might correspond to the poorly fossiliferous lower portion of the Hannibal of Missouri. Lithologically the Maple Mill is more like the Saverton shale than like the Hannibal shale. If the Hannibal shale overlaps on to the Saverton-Maple Mill surface, it may be that the English River is the only portion of the Hannibal represented in Iowa. In this case the Saverton of Missouri would be correlated with some portion of the Maple Mill. In time position the Louisiana limestone would occupy the interval between the deposition 
of the Maple Mill and the English River. At present this problem cannot be definitely settled.

\section{THE ENGLISH RIVER FORMATION}

The exposures of the English River formation are confined to the southeastern Iowa province with the exception of a few exposures along Iowa river near the city of LeGrand in Marshall county.

Distribution and Thickness.-The exposures of the English River formation are limited to the bluffs of Mississippi, Iowa and English rivers and their tributary streams. The English River is very well exposed at the city of Burlington and in the creek valleys immediately north of the city. In the northern part of Des Moines county the English River dips beneath the level of the flood plain of Mississippi river and is not exposed again until Smith creek in Louisa county is reached. Several good exposures are found in the creeks that enter Iowa river from the south in Louisa county and these exposures are particularly well developed in the lower basin of Long creek south of Columbus Junction. Very good exposures are found along the bluffs of English river in Washington county, where the type sections are located. The best exposures are located in the old clay pits one mile* south of the town of Kalona in the south bluff of the river. The next place where the English River is exposed is over 100 miles to the northwest of Washington county in the Iowa river valley near LeGrand.

The English River formation differs somewhat in thickness at various localities. This is due mainly to a small unconformity at its top where considerable material has been removed locally; At Burlington its average thickness is about $22 \mathrm{feet}$, in Louisa county it is rarely over 15 feet, and in Washington county it would average less than eight feet. Abrupt local variations are found in certain localities, however.

Lithologic character.-The English River formation consists of massive blue siltstone ledges in which the individual grains are of clear white quartz. Mechanical analysis shows that 70 per cent of the material falls in the $1 / 16$ to $1 / 32 \mathrm{~mm}$. size grade. Practically none of the material is larger than this. The majority of the crystals show good crystal boundaries and as a whole the material shows little 
evidence of transportation. The color of the material is usually blue or gray, much like the underlying Maple Mill shale. Occasionally the upper beds are of a brownish yellow color. This color is developed just below the contact of the English River with the overlying formations.

Stratigraphy.-The English River lies with apparent conformity on the Maple Mill formation and is differentiated from the Maple Mill only by its massive sandy nature and its abundant fossil remains. It has been considered to be the upper fossiliferous part of the Maple Mill formation.

In the greater part of its area in Iowa the English River lies unconformably beneath the Hampton formation. In Missouri apparently no such relation exists between the Hannibal and Chouteau formations.

At Burlington the English River appears to underlie the Hampton conformably. Several of the species of fossils found in the English River continue right across the line. The only suggestion of a break between the two formations at Burlington is found in the leached yellow ledge at the top of the English River formation. This material is thought to have been leached after the retreat of the English River sea and before the advance of the Hampton sea.

To the north and west of Burlington this unconformity becomes more and more marked. It is very clearly marked in Washington county in the type sections of the English River. In the exposures in Iowa river valley near LeGrand the English River is represented by a conglomerate of large blocks in which nearly every zone of the English River is found.

This stratigraphic break will be taken up in detail in a separate chapter at the end of the description of the Hampton formation of the southeastern Iowa province.

Paleontology.-The English River fauna is one of the most distinctive and most easily recognized faunas in the Iowa Kinderhook. It contains a very characteristic assemblage of fossil species that do not occur together in any other part of the series. The fauna is exceptionally prolific both in individuals and in species. The fossils are always preserved as casts in this sandy material. 
The fauna of the English River at Burlington has been fully listed by both Weller $^{8}$ and $\mathrm{Van}^{\mathrm{Tuyl}}{ }^{9}$ and will not be repeated here.

Faunal list from the English River at the railroad cut exposure in the northeast corner of section 19, R. $3 \mathrm{~W}$., Tzup. $73 \mathrm{~N}$., in Louisa county.

Brachiopoda

Schellwienella inaequalis (Hall)

Chonetes illinoisensis Worthen

Productus mesicostalis Weller

Productus curtirostris Winchell

Productella concentrica Hall

Orbiculoidea capax White

Schizophoria swallovi (Hall)

Schizophoria sp.

Productella numularis (Winchell)

Paryphorhynchus transversum Weller

Composita corpulenta (Winchell)

Spirifer subrotundus Hall

Syringothyris extenuatus Hall

Eumetria altirostris White

Pelecypoda

Posidononya ambigua Winchell

Grammysia amygdalinus Winchell

Grammysia plena Hall

Edmondia aequimarginalis Winchell

Edmondia burlingtonensis $W$. and $W$.

Edmondia quadrata $W$. and $W$.

Mytilarca occidentalis W. and W.

Schizodus iowensis Weller

Goniophora jennae Winchell

Pterinites whitei Winchell

Gastropoda

Bellerophon panneus White

Bellerophon bilabiatus $W$. and $W$.

Murchisonia quadricincta Winchell

Strophostylus bivolve $W$. and W.

Platyschisma barrisi (Winchell)

Platyschisma depressa Weller

Naticopsis depressa Winchell

Pteropoda

Dentalium grandaevum Winchell

Cephalopoda

Orthoceras indianense Hall

Orthoceras whitei Winchell

The following faunal list was made from collections taken trom the abandoned clay pits one mile south of Kalona.

Brachiopoda

Orbiculoidea capax (White)

Schellwienella inaequalis (Hall)

Productus mesicostalis Weller

Productus curtirostris Winchell

Productella numularis (Winchell)

Chonetes illinoisensis Worthen

Chonopectus fischeri $N$. and $P$.

Schizophoria swallovi (Hall)

B Weller, Stuart, St. Loui's Acad. of Sci. Vol. 10, p. 57, 1900.

- Van Tuyl, Iowa Geol. Survey, Vol. XXX, p. 59, 1922 . 


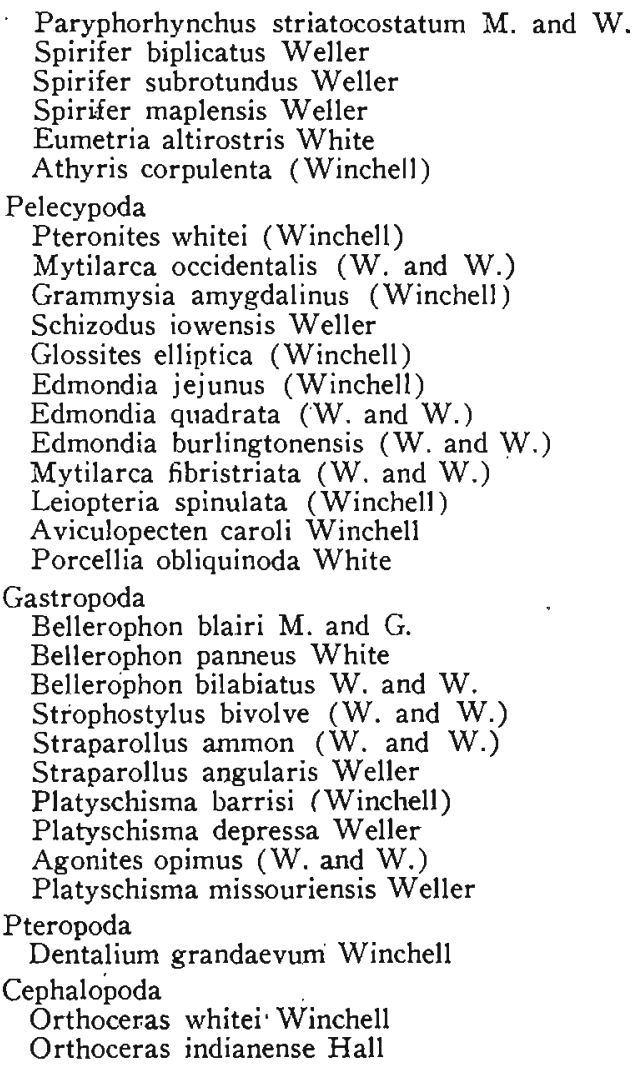

The English River formation differs considerably in thickness throughout the region, owing mainly to the unconformity at its top. It is possible to distinguish in the formation different fossiliferous zones which must be defined by the fauna alone because of the similarity of the lithology throughout. The maximum thickness of the formation in Iowa is about 32 feet. The lower 22 feet of this section may be seen at Burlington and the upper part may be seen at only a few places along English river in Washington county. The best exposure of this upper part may be seen on the south bank of English river at 82 of section 8 , Range 8 West, Township 77 North.

One part of the English River contains a faunal assemblage that is definite enough to be used as a datum plane. This will be designated as the Chonopectus fischeri zone. This zone is about six feet thick and is characterized mainly by a great number of individuals of the 'species named. At Burlington the zone is found at the top of the English 
River section and may be found at this same stratigraphic position at a number of places in the region. However, in the English river basin a.considerably different relation is often found. At several exposures the zone is missing entirely and at several other exposures it is found to be a considerable distance down in the section. This relation is due to the unconformity that bevels its surface in this locality.

The Chonopectus fischeri zone should be established by paleontological methods rather than by stratigraphy. Individuals of this species crowd the beds of this zone, and associated with this form are found great numbers of Chonetes logani. Paryphorhynchus striatocostatum occurs only rarely outside of this zone while Spirifer biplicatus, Syringothyris extenuatus and Schellwienella inaequalis occur much more abundantly in this zone than in any other part of the formation.

English River at LeGrand.-The English River beds are exposed beneath the Hampton formation along Iowa river in the west part of Tama county and in the east part of Marshall county. These exposures are found at intervals along either side of the river for a distance of about two miles from the old mill one mile north of LeGrand in Marshall county, to the town of Butlerville, in Tama county.

At only one place in the area are English River strata actually exposed but their contact with the overlying limestone is marked by a line of bog springs. By digging in the bluffs near these springs a contact may often be exposed. In the exposure at the old mill a mile north of LeGrand about eight feet of greenish shaly material may be seen underlying the oölitic limestone. The contact between the two formations appears to be unconformable. None of this material is fossiliferous, so it is not possible to state whether it should be classed with the Sheffield formation or with the English River.

At an old quarry at 77 of section 9, Indian Village township, in Tama county, an exposure that proved to be very fossiliferous was made by digging. The exposure consists of a conglomerate of large blocks of English River material. These blocks were all tumbled together and cemented with travertine in a striking manner. Fossils from many different horizons in the formation were found in these blocks. A few of the blocks were almost unfossiliferous while others were exceptionally fossiliferous. The entire thickness of the formation at this place was not over three feet, and its contact with a soft 
bluish green shale was easily exposed by more digging. The break between the English River conglomerate and the overlying oollitic limestone was very sharp and appeared to be unconformable.

This conglomerate probably represents blocks of English River material that rolled from some nearby elevation into small valleys excavated in the Maple Mill or Sheffield formations during the period of erosion following the deposition of the English River. This exposure is over 100 miles northwest of the nearest known English River exposures.

English River fauna collected from the exposure at 77 of Section 9, Indian Village tounship, Tama county.

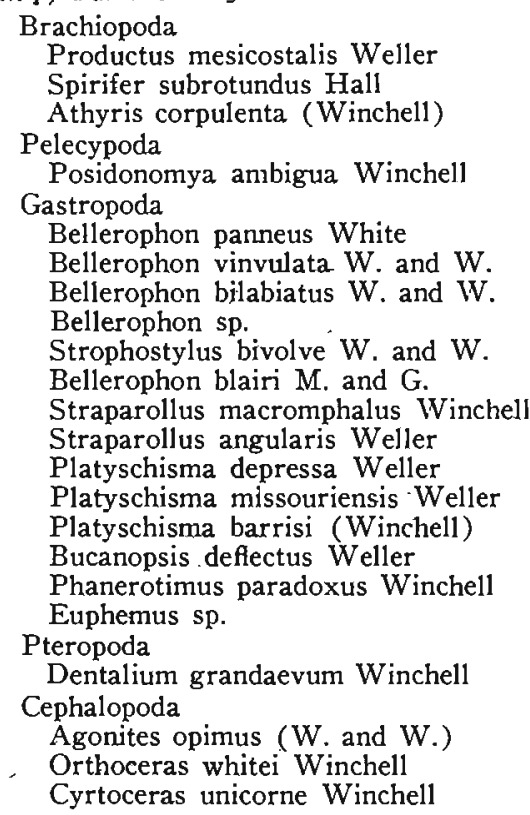

The brachiopod and pelecypod elements are noticeably absent in this western development of the English River formation. The most abundant species in this fauna is the large Platyschisma missouriensis.

Correlation.-The English River has been correlated with the Hannibal formation of Missouri by Weller, Van Tuyl, and Moore. Of the 28 species of brachiopods found in the Hannibal of Missouri 12 are found in the English River. Of the 15 species of pelecypods found in the Hannibal nine are found in the English River. The gastropod element in the Hannibal is very small, with only four representatives, and of these only one is found in the English River. Two cephalopods 
are found in the Hannibal and one of these occurs in the English River. The English River fauna contains 48 per cent of the Hannibal species.

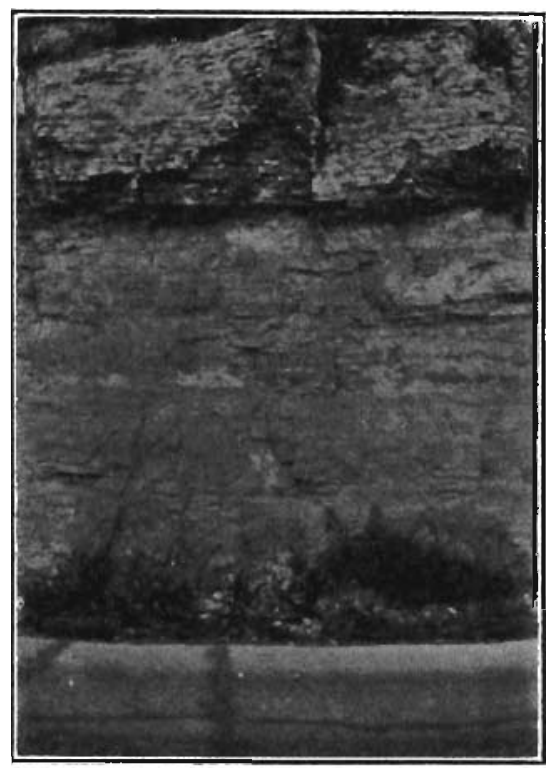

FIg. 48.-English River exposed at North Hill, Burlington, Iowa.

\section{THE HAMPTON FORMATION}

The lower members of the Hampton formation are exposed in the southeastern province in Iowa. In this province the Hampton has been divided into two members, the North Hill at the base and the Wassonville overlying. - The North Hill member is named from the road cut around North Hill in the city of Burlington, where a complete section of the member may be seen. The Wassonville member corresponds to the Wassonville limestone as delimited by Bain ${ }^{10}$ in 1896.

The North Hill Member

The North Hill member contains all Kinderhook beds above the English River formation and below the brown dolomites of the Wassonville member. It corresponds to beds $3,4,5$ and 6 of Weller. ${ }^{11}$

Distribution and Thickness. - The North Hill member has a limited distribution in the southeastern province and is exposed best in the immediate vicinity of Burlington. Exposures may be traced northward

10 Bain, H. F., Geol. of Washington County, Iowa Geol. Survey, Vol. V, p. 134, 1895.

11 Weller, Stuart, St. Louis Acad. of Sci., Vol. 10, p. 61.1900. 


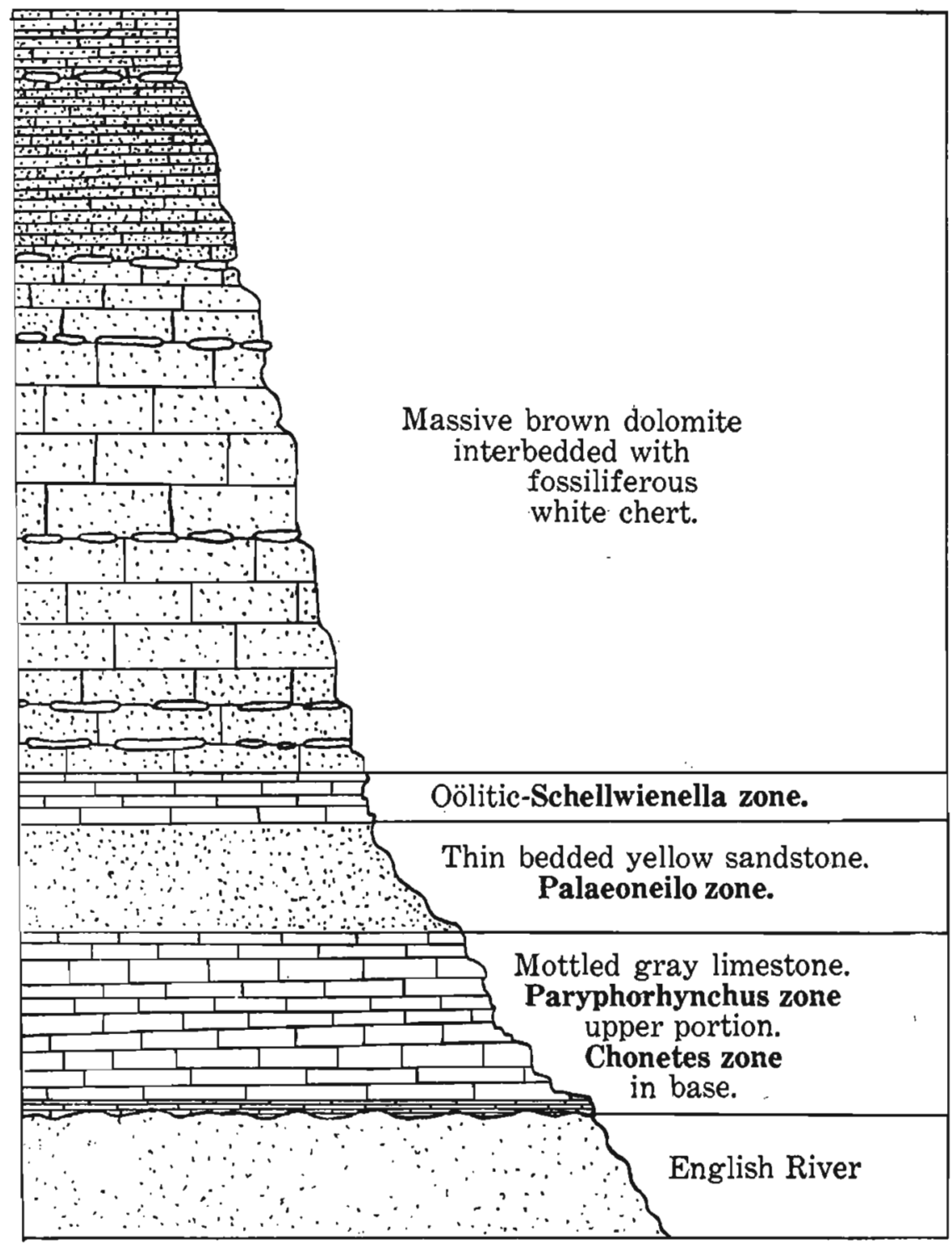

Fic. 49.-Wassonville and North Hill members of the Hampton formation in southeastern Iowa. The uppermost group of beds is referred to the Wassonville and the three underlying are referred to the North Hill. Scale: 1 inch equals 16 feet.

along the Mississippi bluff throughout the entire length of Des Moines county. In the lower valleys of the creeks that are tributary to Mississippi river limited exposures of the member may be seen.' 
In Louisa county the exposures are not so abundant, but they may be identified in the valleys of the creeks and along Iowa river bluff as far west as Honey creek near Morning Sun. These exposures in Louisa county represent only the upper beds of the member. The best exposure of the member in this county may be seen in the county quarry at 113 of section 23, Range 3 West, Township 73 North. The entire section of the North Hill member may be seen here, and its relations to the underlying English River and the overlying Wassonville are clearly shown. At this point the member is only eight feet thick.

The North Hill member is approximately 20 feet in thickness at the city of Burlington, but as it is traced to the north and west the lower layers pinch out against the underlying English River formation. In the lower valley of Smith creek in Louisa county it is only 15 feet in thickness and slightly farther west on Honey creek it is only eight feet thick. In the lower valley of Long creek south of Columbus Junction it cannot be distinguished from the overlying Wassonville dolomite.

Lithologic Character.-Lithologically the North Hill member is not a unit at all. It consists of an oolitic limestone at the base, followed by a semilithographic limestone, followed by a sandstone, and capped with an oölitic limestone.

The units of the North Hill member have been given zone names for the most prominent fossils which they contain. These zones correspond to the beds described by Weller ${ }^{12}$ in 1900 . The following table gives the zone names and their equivalents.

4. The Schellwienella zone is named for Schellwienella planumbona Weller, which characterizes the zone. This zone is equivalent to the oölitic bed 6 of Weller.

3. The Palaeoneilo zone is named for Palaeoneilo barrisi (W. and W.), which occurs abundantly in the horizon. This zone is equivalent to the yellow sandstone bed 5 of Weller.

2. The Paryphorhynchus zone is named for Paryphorhynchus striatocostatum $\mathrm{M}$. and W., which occurs most abundantly in the zone. It is equivalent to the mottled limestone bed 4 of Weller.

1. The Chonetes zone is named for Chonetes gregarius Weller, which crowds certain parts of the horizon. This zone is equivalent to bed 3 of Weller.

The Chonetes zone consists of dark, bluish black thin-bedded lime- 
stone that is in places oölitic in its upper part. The zone is nowhere over nine inches in thickness and is usually filled with more or less fragmented fossils.

The Paryphorhynchus zone is a semilithographic limestone whose lithology is quite similar to that of the upper ledges of the Chouteau at Newark, Missouri. The peculiar coloration of this zone makes it easily distinguishable throughout the region. It appears everywhere as an uneven mottled thin-bedded drab and brown limestone. Each of its individual beds is made up of irregular zones of yellowish drab limestone and darker zones of brown limestone. These color variations are closely spaced within the beds, giving the limestone an irregular mottled appearance on a vertical face. The material is hard, breaks with a conchoidal fracture and is very resistant to weathering.

This limestone is almost identical in lithologic character with the Louisiana limestone. For this reason it has been thought to be a northern extension of this limestone body. The fauna, however, shows definitely that this is not true.

The Palaeoneilo zone consists of about six feet of soft yellow rather thin-bedded sandstone. Under the microscope the material may be seen to consist of irregular particles of pure quartz mainly of the silt size. The cementing material is calcite and limonite. Lithologically the material resembles very much the English River.

The Schellwienella zone consists of about three feet of hard gray rather thin-bedded fossiliferous oölitic limestone. The zone is rather constant in thickness over the whole area of exposure.

Stratigraphy.-The North Hill member lies disconformably on the English River formation. The unconformity is not well shown in this immediate region of the southeastern province because of a lack of exposures in which the contact between the North Hill member and the English River formation may be seen.

The North Hill member can be demonstrated to overlap on to the English River surface. Each of the zones from the base upward may be traced a little farther to the northwest. Only the upper zones of the member are present in Louisa county. In Washington county the Wassonville member lies directly on the English River.

The North Hill member underlies the Wassonville member conformably. The lithologic break between the oollitic limestone of the North Hill member and the dolomite of the Wassonville member is 
sharp, but the fauna continues into the overlying beds with little or no break.

Paleontology and Correlation.-The fauna of the North Hill member has been listed by Weller ${ }^{18}$ in 1901, by Van Tuyl ${ }^{14}$ in 1922 and by Moore $^{15}$ in 1928.

This fauna is quite closely related to that of the underlying English River formation. There are 88 species listed from the underlying English River and Maple Mill formations in Iowa and 22 of these are found in the North Hill member. When the entire faunal assemblage is considered these species must be regarded as holdovers in the new formation from the English River. The Chouteau element is by far the most prominent in the fauna.

The North Hill fauna contains a large number of species that occur in the fauna of the Chouteau at Newark, Missouri. Moore has listed 71 species from the Newark beds and of these 24 are found in the North Hill member. There are 38 brachiopods present in the Newark fauna and of these 17 occur in the North Hill fauna.

The North Hill member contains most of the common index fossils of the members of the Hampton formation that overlie it. The fauna of the Chonetes zone is small and helps very little in correlation. The fact that it is a limestone would tend to place it in the Hampton formation rather than in the English River because the English River has no limestone whatsoever. The occurrence of Rhipidomella burlingtonensis also suggests the Hampton formation.

The fauna of the Paryphorhynchus zone also is limited. Paryphorhynchus striatocostatum and Rhynchopora pustulosa occur abundantly in the zone and both are characteristic fossils of the Hampton formation. The lithology of this bed is very similar to that of the upper part of the Chouteau section at Newark, Missouri.

The Palaeoneilo zone contains a very abundant fauna in which are found for the first time many of the index species that range throughout the entire Hampton formation. The presence of Spirifer platynotus, Camarophorella lenticularis, Productus arcuatus, Leptaena analoga, Reticularia cooperensis, and Bucanopsis perelegans is very characteristic of the Hampton formation and an important number of these species are found in the Chouteau of Missouri. On the basis of

18 Weller, Stuart, St. Louis Acad. of Sci., Vol, 11, p. 147, 1901.

14 Van Tuyl, F. M.; Iowa Geol. Survey, Vol. XXX. p. 58, 1922, 
these Chouteau species these lower three zones are correlated with some portion of the Chouteau of Missouri rather than with the Hannibal.

The Schellwienella zone has been correlated by Moore $^{18}$ with the Chouteau. The fauna contains many species that are characteristic of both the Chouteau of Missouri and the Hampton of Iowa. Schellwienella inflata, Leptaena analoga, Chonetes logani, Productus arcuatus and Productella concentrica are characteristic of the Missouri Chouteau. Spirifer platynotus, Schellwienella planumbona, Productus arcuatus, Athyris crassicardinalis and Straparollus obtusus are characteristic of the Hampton of Iowa.

The North Hill member is seen again in the north-central province at LeGrand, in Marshall county. Here the cherty Wassonville member is underlain by 18 feet of gray oölitic limestone that contains a fauna very similar to the fauna of the Schellwienella zone of the North Hill member. Farther north in Franklin county the North Hill member is represented by the Chapin, which consists of about 30 feet of hard gray limestone overlain by oölitic limestone. The Chapin section probably has beds in its base which are older than the North Hill member.

It is difficult to state just which part of the Chouteau of Missouri the North Hill member represents. Lithologically the base of the North Hill resembles the upper part of the Chouteau at Newark, Missouri. It is the opinion of the writer that the North Hill member is equivalent to the upper part of the Chouteau of Missouri.

\section{The Wassonville Member}

Distribution and Thickness.-The Wassonville member is exposed quite extensively in the southern province. In the northern province its equivalent horizon, the Maynes Creek, also is very well exposed.

In the southeastern province the Wassonville member may be seen capping the oölitic limestone of the North Hill member-and underlying the Lower Burlington limestone in all of the exposures in the vicinity of Burlington. It is exposed at a number of places along the bluffs of Mississippi river in Des Moines county. In Louisa county it is very well developed along the southern bluff of Iowa river and in the adjacent creek valleys. The best exposures are along the bluffs of English river in Washington county, where the type sections are located. The type section from whence the name is derived is located at the old Wassonville mill on the south bluff of English river two miles

18 Moore, R. C., Missouri Bur, of Geol, and Mines, Vol. 21, 2d Ser., p. 22, 1928. 
north of Daytonville. To the west of Washington county the Wassonville is very poorly exposed in the southeastern province. The Wassonville cherts may be seen occasionally in the creek beds but for the main part the exposures are missing. The northernmost exposure of the Wassonville in the southeastern province is at the town of Amana, in Iowa county. Here about 15 feet of yellow dolomite filled with fossiliferous chert may be seen in the exposure on Price creek in the northern part of the town.

The maximum thickness of the Wassonville member is about 45 feet. It very likely once had a much greater thickness, as concentrates of chert are usually found capping its sections. Its equivalent member, the Maynes Creek, in the northern province attains a much greater thickness. The thickness of the member differs considerably in the area owing to the presence of unconformities both above and below. The minimum thickness of the member may be seen in the vicinity of Burlington, where it is in very few places over five feet thick.

Lithologic character. - The main portion of the Wassonville is a brown massive dolomite in which the beds would average over a foot in thickness, with the exception of the upper ledges. The solubility of the material runs up as high as 94 per cent. Microscopically the material consists of many dolomite rhombohedrons cemented together with calcite and limonite. The maximum sizes belong in the $1 / 16$ to $1 / 32 \mathrm{~mm}$. size grade, which places the material among the silts.

The Wassonville is particularly characterized by its chert bands, which may be white, black or banded. At least 95 per cent of the chert would be considered as white, however. Between most of the bedding planes may be seen long lenticular masses of chert that at some places appear to be continuous and at others are represented by a discontinuous row of nodules. These chert masses are in most cases crammed with fossils. In a few of the exposures the chert has weathered to a crumbly mass of white powder and in these exposures it is very easy to obtain the fauna. The chert bands range in thickness from about eight inches to less than two.

Stratigraphy of the Wassonville member.-The Wassonville member conformably overlies the North Hill member in the southeastern part of the province. However, in the English river basin in Washington county the Wassonville overlies the English River directly and is disconformable. Evidence will be given to show that the Wassonville 
overlies the Maple Mill directly at some places although the actual contacts are not exposed. The Wassonville also overlies the Sheffield directly in one exposure in the southeastern province.

The Wassonville member contains a series of white chert bands that can be definitely distinguished from each other by their distinctive faunas. In the English river basin are four of these chert bands that occupy rather definite stratigraphic horizons. The uppermost of these four bands carries a fauna that may be very easily recognized and will therefore be used as a datum plane over a short distance in the English river basin.

The upper chert band that is to be used as a datum plane may be distinguished from the other three very easily. It is composed mainly of fragmented stems and plates of crinoids. Plates of several species of Platycrinus, a Rhodocrinus and a Cactocrinus may be distinguished. Intermingled with the crinoidal fragments may be seen other species that are characteristic of this chert band alone. A small form of Leptaena analoga occurs very abundantly and appears to be confined to this horizon. Two species of Rhombopora, two of Cystodictya and one of Fenestella are very common in the horizon. The presence of the crinoidal material, the numerous bryozoa, and the small form of Leptaena are definite indications of this horizon within the English river valley.

The English River-Hampton unconformity.-The English River formation of Iowa has been thought by many to underlie the limestones of Hampton age conformably. No previous writer has placed a disconformity between the English River and the upper limestone of Kinderhook age. No break of any kind is recognized between the Hannibal and Chouteau formations of Missouri. The Hampton of Iowa is equivalent to part of the Chouteau of Missouri and the English River has been correlated with the Hannibal.

It is one of the purposes of this paper to demonstrate the unconformity between the English River formation and the overlying Hampton formation. It should be kept in mind that the author is dealing only with the strata that are exposed in Iowa and that this unconformity need not be projected into Missouri. It is evident that the faunas of the English River and Hampton formations are very closely related and that at some place there was continuous sedimentation between the two formations. It is possible that although there is a marked break 
between the formations in Iowa there might have been continuous deposition in Missouri. Furthermore the unconformity that exists at the base of the Hampton formation is much more sharply marked in the northern part of the state than in the southern.

The Hampton formation overlaps on to beds of older age. In the southeastern province it overlaps on to the English River surface and the Maple Mill surface, and finally at a few localities it may be seen resting directly on shales of Sheffield age. In the north-central province the Hampton rests on the English River at one locality in the very southern part of the province. At all other places in the north-central province it rests unconformably on different members of the Sheffield formation.

The faunal break between the two formations is not at all sharp at Burlington. Several species found in the English River at Burlington continue on into the North Hill member. At all other localities in Iowa the faunal break is very sharp. The sharp faunal break was one of the direct causes for the work that has been done on this contact.

It is obvious that it would not be possible to determine such an unconformity by direct observation on the sections. The largest and best exposures are seldom over a score of feet in length. The presence of the thick overlying drift in Iowa forces the stratigrapher to use fossil zones in determining his horizons and therefore definite life zones have been established in both the English River and Hampton formations. It is largely through the tracing of these life zones areally that this unconformity has been established.

The zones of the North Hill member pinch out against the English River surface to the northwest of Burlington. The member is known to definitely overlap on to the English River, for each of the zones in order from the base upward may be traced a little farther to the northwest. The Chonetes zone may be distinguished only in the immediate vicinity of Burlington. The Paryphorhynchus zone is exposed in the valleys of the creeks that enter Mississippi river in the northern part of Des Moines county. It is represented by a thin dolomitic bed in a few of the easternmost creek valleys that enter Iowa river in Louisa county. Both Palaeoneilo and Schellwienella zones may be seen on Smith creek below the wagon bridge at 46 of section 31, Range 3 West, Township 73 North. The Schellarienella zone is exposed in the lower valley of Honey creek to the north and east of Morning Sun. In the 
valley of Long creek south of Columbus Junction the whole North Hill member is represented by five feet of brownish dolomite. In the English river valley in Washington county none of the North Hill member is present.

The unconformity between the two formations is very well shown in the English river valley. At all known exposures in this area the Wassonville rests on the English River. Descriptions will be given of the relations between the two formations at four different localities along English river from Kalona to the old Wassonville mill, which is six miles up English river from Kalona.

The Kalona clay pit section is located on the south bluff of English river at 11 of section 19, Range 7 West, Township 77 North. About six feet of English River gritstone may here be seen overlying the Maple Mill shales and underlying about ten feet of Wassonville dolomite. The English River material is all below the Chonopectus fischeri zone and represents only the lower blue-gray ledges, which are filled with molluscs. The basal portion of the Wassonville consists of about six feet of soft blue-gray shale filled with irregular chunks of English River gritstone. In this clay pit the shale bed ranges from six feet to less than two feet in thickness and carries the characteristic Wassonville fish fauna in its base. Only occasional fish teeth may be found at this locality, but at certain other localities in the immediate vicinity fish tooth conglomerates may be found at this horizon. This shale consists of material from the Maple Mill and English River surfaces that has been reworked by the encroaching Hampton sea and concentrated in the base of the Hampton. The basal portion of the dolomite which overlies this shale has present in it a considerable amount of reworked English River grit.

The contact of the Wassonville member with the English River is eight feet below the crinoidal chert band of the Wassonville. The typical Wassonville dolomite ends two and one-half feet below the crinoidal chert band.

The second section is located on the south bank of English river about one hundred feet downstream from the wagon bridge at 81 of section 8 , Range 8 West, Township 77 North. At this point about 20 feet of English River material may be seen overlying the Maple Mill shale and underlying the Wassonville. The English River section includes the entire Chonopectus fischeri zone and eight feet of material 
that lies above this zone. The upper surface of the English River, on which the Wassonville rests, is filled with solution-pits and the whole upper part is of a peculiar reddish color that probably was caused by weathering before the deposition of the Wassonville. The contact of the English River with the Wassonville at this point is three feet below the upper crinoidal chert band of the Wassonville. ${ }^{17}$

The basal six inches of the Wassonville in this second section consists of reworked English River material mixed with dolomite. Lithologically it is almost identical with the true English River material. It contains a remarkable fish fauna and also an invertebrate fauna that is typically Wassonville in age. These fish remains are often concentrated immediately on the contact between the two formations, but occasionally they occur slightly above the contact. The English River surface is full of solution pits and in these pits are concentrated scores of fish teeth, plates and spines.

Next above the fish tooth bed may be seen about ten inches of reworked Maple Mill shale filled with fragments of English River material. The presence of Maple Mill shale in the Wassonville section shows that at some nearby place erosion had cut entirely through the English River into the Maple Mill and that the encroaching Wassonville sea was rehandling the material and depositing it in its basal ledges.

The true Wassonville dolomite begins just above this shale bed. The lower part of the dolomite contains large amounts of reworked English River material but attains its true dolomitic character a short distance above its contact with the shale. The base of the dolomite contains a few scattered fish teeth and an invertebrate fauna of 37. species.

The third section is located one mile up English river from the second section in an abandoned quarry on the north bluff of the river at 69 of section 6, Range 8 West, Township 77 North. The contact of the English River with the Wassonville is not exposed in this quarry but may be seen a few rods downstream. It is assumed that the quarry floor is very near the contact. In this quarry there are 26 feet of Wassonville dolomite below the crinoidal chert band. All four of the chert bands are present.

A short distance downstream on the same side of the river the

17 A small quarry at 399 of Section 16, Range 8 West, Township 77 North, approximately half way between the Kalona clay pit and the second section, shows three chert bands and twelve feet of Wassonville dolomite underlying the crinoidal chert band. 
contact of the English River with the Wassonville is exposed. The Wassonville at this point rests directly on the Chonopectus fischeri zone and only about 12 feet of dolomite is present below the crinoidal chert zone:

The fish tooth bed is present again in the base of the Wassonville. These fish teeth are present in the base of the Wassonville in nearly all of the exposures, but at none of them are the teeth located at exactly the same stratigraphic horizon. Evidently the fish were washed ashore after death and rolled back and forth in the waves until they were broken to fragments. This action would concentrate their remains directly on the contact between the two formations and would explain also their varying stratigraphic position. Fish teeth occur all through the Hampton formation, but at no place except at the base of the formation are they gathered into typical fish tooth conglomerates.

The Wassonville Mill section is located on the south bank of English river one mile north of Daytonville. This section shows practically the same relation to the English River as the last described section. Twenty-five feet of Wassonville dolomite may be seen below the crinoidal chert horizon. The Wassonville quarry is still in operation and this fact makes possible the collection of large numbers of fossils from the soft chert nodules that are thrown aside during the quarrying operation.

The Wassonville section shows fairly well the relation of the upper part of the section to the Maynes Creek member of the same age in the northern province. Above the typical section may be seen about 20 feet of fragmented chert and weathered dolomite which were concentrated at the top of the section by weathering of the dolomite. The Wassonville of the southeastern province was probably as thick as the Maynes Creek of the northern province.

The Wassonville at Amana.-The Wassonville dolomite is exposed in the northern part of the town of Amana, in Iowa county. The exposure is located within the city limits in the south bank of Price creek about 50 feet downstream from the bridge. At this point about 15 feet of Wassonville dolomite carrying its typical chert bands may be seen overlying the blue dolomitic shales of the Sheffield formation. The blue dolomitic shales carry a typical Sheffield fauna. The Wassonville dolomite has overlapped the English River and the Maple Mill and in this section rests unconformably on the Sheffield. Shales in thicknesses as 


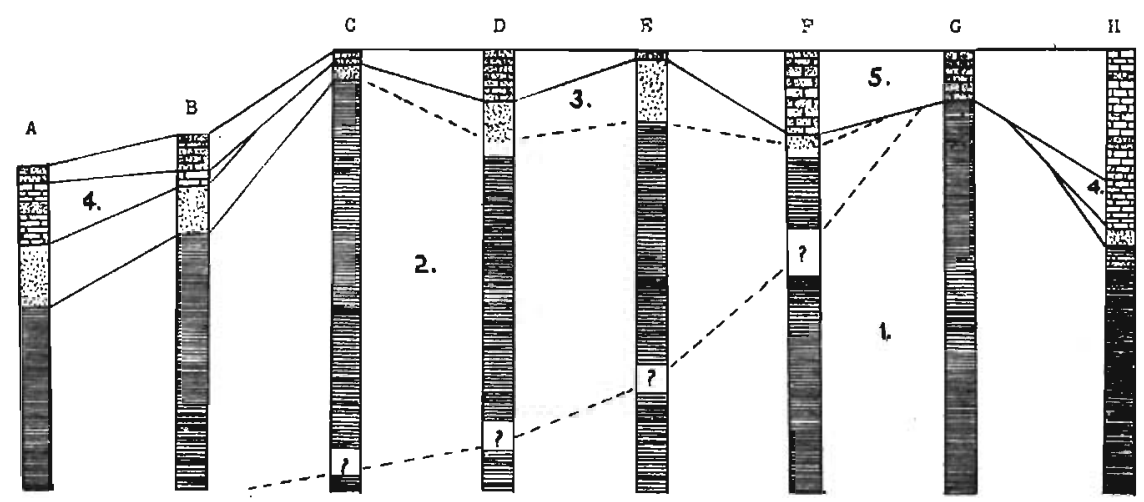

Frc. 50.-Kinderhook Correlation Chart for Southeastern Iowa (Crinoidal chert band in top of Wassonville is used for a datun plane). Vertical scale: 1 inch equals 100 feet.

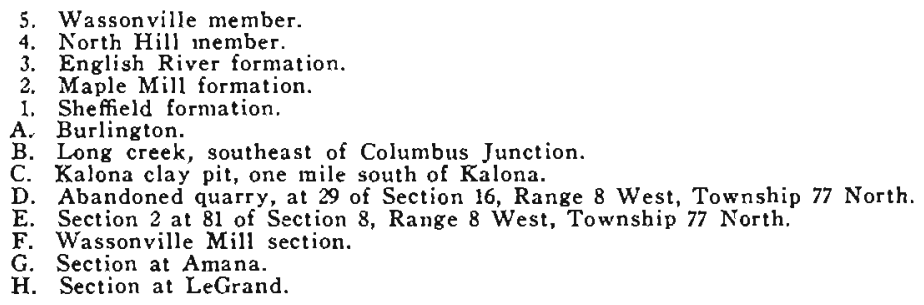

much as 175 feet that have been referred to the Maple Mill are found in well sections to the south and west of here. The English River is actually exposed over 100 miles northwest of Amana. It would seem that a large amount of erosion must have taken place before the Wassonville could have been deposited directly on the Sheffield in this region.

The English River of Marshall and Tama counties.-The English River is exposed along Iowa river in the eastern part of Marshall county and in the western part of Tama county. It consists here of a conglomerate of large blocks cemented with travertine. The conglomerate represents blocks of English River material that had tumbled down into a small valley that had been eroded in the Maple Mill or Sheffield formations before the deposition of the Hampton.

In this section may be seen 18 feet of oölitic limestone that is equivalent to the upper part of the North Hill member at Burlington. This oölitic limestone overlies the English River and is overlain by the typical brown dolomites filled with chert bands. 
Summary of the evidence for the English River-Hampton unconformity.

1. The Hampton formation overlaps and rests on three different formations.

2. Abrupt changes in the thickness of both the upper part of the English River and the base of the Hampton are seen.

3. The North Hill member occupies a low in the English River surface.

4. The oölitic limestone at LeGrand also occupies a valley that was eroded before the daposition of the oölite.

5. The fish tooth conglomerate is developed along the shore line of an encroaching sea and occupies many different horizons in the Wassonville.

6. Reworked material from underlying formations is found in the base of the Hampton.

7. The upper surface of the English River is in places leached and covered with solution pits.

In the southeastern province the Wassonville member is unconformably overlain by the Burlington limestone, which overlaps on to the eroded Wassonville surface. The different zones of the Burlington limestone are easily identified and each of these zones in succession from the base upwards may be seen in contact with the Wassonville from Burlington to Wassonville. In the bed of the first creek that enters Iowa river above the Wassonville mill the upper zone of the Upper Burlington limestone may be seen in contact with the Wassonville. In the basin of Long creek, south of Columbus Junction, the green limestone zone that marks the lower part of the Upper Burlington may be seen in contact with the Wassonville. Farther to the south the zones of the Lower Burlington may also be seen in this relation.

The Wassonville increases in thickness correspondingly as the Burlington decreases throughout this distance. At Burlington it is six feet in thickness and to the northwest the thickness gradually increases.

Paleontology and Correlation.-The fauna of the Wassonville cherts has proven to be the most prolific of the entire Hampton formation and it marks a definite horizon that is easily recognized throughout both provinces. The chert fauna is particularly desirable because of the excellent preservation of the fossils found in it.

Fossils are found also throughout the dolomite in which this chert occurs. In the dolomite, however, the fossils are represented only by 
very poor casts. In the base of the dolomite where much reworked English River grit is found the casts are much better.

Complete Fauna of the Wassonville Member

Zaphrentis cliffordana $\mathrm{E}$. and $\mathrm{H}$.

Platycrinus sp.

Platycrinus sp.

Rhodocrinus sp.

Leptaena analoga (Phillips)

Schellwienella inaequalis (Hall)

Schellwienella planumbona Weller

Schellwienella crenulicostata Weller

Schellwienella inflata (White and Whitfield)

Schellwienella sp.

Streptorhynchus sp.

Chonetes logani Norwood and Pratten

Chonetes illinoisensis Worthen

Chonetes glenparkensis Weller

Chonetes multicostata Winchell

Productus ovatus Hall

Productus arcuatus Hall

Productus sp.

Productella concentrica (Hall)

Rhipidomella thiemei (White)

Schizophoria subelliptica (White and Whitfield)

Schizophoria chouteauensis Weller

Camarotoechia chouteauensis Weller

Camarotoechia tuta (Miller)

Dielasma chouteauensis Weller

Cranaena occidentalis Miller

Rhyrichopora pustulosa (White)

Spiriferina solidirostris (White)

Spiriferina subtexta (White)

Spiriferina sp.

Spirifer legrandensis Weller

Spirifer platynotus Weller

Spirifer biplicoides Weller-

Spirifer louisianensis Weller

Spirifer sp.

Brachythyris peculiaris (Shumard)

Syringothyris halli (Winchell)

Cliothyridina sp.

Reticularia cooperensis (Swallow)

Eumetria osagensis (Swallow)

Nucleospira barrisi White

Trigeria sp.

Cardiopsis radiata $M_{\text {. }}$ and $W$.

Palaeoneilo barrisi $W$. and $W$.

Edínondia jejunus Winchell

Grammysia amygdalinus Winchell

Nucula iowensis Weller

Nucula glenparkensis Weller

Leda sacata (Winchell)

Liopteria subovata M. and G.

Schizodus trigonalis Weller

Schizodus sedaliensis M. and G.

Aviculopecten sp.

Pernopecten cooperensis (Shumard)

Pernopecten sp. 
Cypricardinia sulcifera (Winchell)

Sphenotus sp.

Bellerophon blairi Winchell

Bucanopsis perelegans $W$. and $W$.

Bucanopsis sp.

Strophostylus bivolve W. and W.

Porcellia sp.

Platyschisma depressa Weller

Straparollus lens Hall

Straparollus macromphalus Winchell

Phanerotinus paradoxus Winchell

Loxonema sp.

Loxonema sp.

Pleurotomaria sp.

Murchisonia sp.

Murchisonia sp.

Euphemus sp.

Euphemus sp.

Worthenia sp.

Warthia sp.

Aclisina sp.

Holopea conica Winchell

Goniatites sp.

Orthoceras indianense Hall

Gyroceras sp.

Dentalium grandaevum Winchell

Proetus sp.

The following fauna was collected from the Wassonville dolomite about eight inches above its contact with the English River at 81 of section 8 , Range 8 West, Township 77 North.

Schellwienella crenulicostata Weller

Schellwienella planumbona Weller

Schellwienella inaequalis (Hall)

Schellwienella sp.

Streptorhynchus sp.

Chonetes logani Norwood and Pratten

Chonetes sp.

Productus arcuatus Hall

Productella cf. concentrica (Hall)

Rhipidomella thiemei (White)

Schizophoria subelliptica (W. and W.)

Schizophoria chouteauensis Weller

Spirifer platynotus Weller

Spirifer biplicoides Weller

Spirifer louisianensis Weller

Brachythyris peculiaris (Shumard)

Syringothyris halli (Winchell)

Cliothyridina sp.

Reticularia cooperensis (Swallow)

Nucleospira barrisi White

Edmondia jejunus Winchell

Palaeoneilo barrisi $W$. and $W$.

Cardiopsis radiata $M$. and $W$.

Elymella missouriensis M. and G.

Pernopecten cooperensis (Shumard)

Sphenotus sp.

Schizodus sp. 
Bellerophon blairi Winchell

Bucanopsis perelegans $W$. and $W$.

Bucanopsis sp.

Strophostylus bivolve W. and W.

Phanerotinus paradoxus Winchell

Straparollus sp.

Loxonema sp.

Loxonema sp.

Orthoceras sp.

Gyroceras sp.

The Wassonville fauna is very definitely a late Kinderhook fauna. The most common species found in the Wassonville occur also in the Chouteau of Missouri. On the basis of this Chouteau fauna the Wassonville is correlated with some portion of the Chouteau of Missouri.

There are forty species in the Wassonville fauna and of these forty, twenty-two are found in the Chouteau at Newark, Missouri. There are twenty-nine species of brachiopods in the Wassonville fauna and twenty of these are found in the Chouteau at Newark.

The most abundant species in the Wassonville fauna are Chonetes multicostata, Spirifer platynotus, Productus arcuatus and Straparollus macromphalus.

\section{Type Sections in Southeastern Iowa}

Section of Kinderhook beds at Prospect Hill, Burlington (After Van Tuyl)

FEET

7. Limestone, soft, buff to brownish, dolomitic; with casts of fossils ; grading up into the lower Burlington limestone ............ 5

6. Limestone, white, oölitic, scaling off obliquely on weathered surfaces 3

5. Sandstone, soft, fine-grained, drab weathering buff, shaly in upper part; some seams filled with casts of fossil shells; bearing occasional

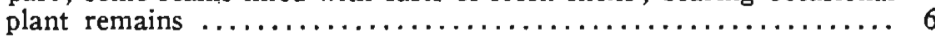

4. Limestone, upper one or two feet brownish and dolomitic. Lower layers consisting of dense gray lithographic-like limestone mottled with small patches of dolomite which in some instances follow small fractures. Small calcite geodes occur in the dolomitic areas, and occasional pockets of sphalerite appear in both the limestone and the

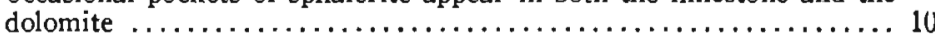

3. Limestone, lower half coarse-grained and filled with Chonetes. Upper half oölitic. Upper surface very undulating, although there is a transition from oölite into limestone above. Contact with bed

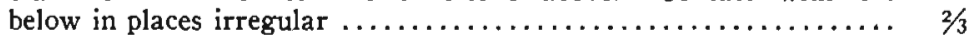

2. Sandstone, fine-grained, soft, drab weathering buff, massive; with occasional thin intercalated layers of shale; upper two feet filled with casts of fossils, most abundant of which is Chonopectus fischeri $221 / 2$

1. Shale, bluish, argillaceous, locally calcareous, drab, sparsely fossiliferous, grading -into beds above. The greatest thickness of this bed is in the old clay pit where 19 feet is shown. Between the bed of the pit and the level of Mississippi river, about 14 feet more is concealed. The total thickness of this member at Burlington, as indicated by deep borings, is probably not less than 300 feet. Exposed 19 
Section Exposed at Clay Pit, Kalona

Wassonville

4. Dolomite, brown, fractured, containing one chert band, fossiliferous, basal part containing much reworked English River grit ......... 5

3. Shale, biue to gray, soft, unctuous, carrying chunks of English River grit. Numerous fish teeth in base ..................... 6

English River

2. Gritstone, blue to gray, massive, very fossiliferous ........... 5

Maple Mill

1. Shale, deep blue to gray, very soft, unctuous, carbonaceous and stained at top, filled with pyrite in lower part, unfossiliferous ...... 14

Section Exposed on South Bank of English River at 81 of section 8,

Wassonville

R. $8 W ., T$ wp. $77 N$.

5. Dolomite, brown, massive, carrying one fossiliferous chert band; gray at base, containing much reworked English River grit. Fossiliferous at base carrying fish teeth and many invertebrates ....... 7

4. Shale, blue to gray, soft, unctuous, containing chunks of English River grit. Scattered fish teeth ..........................

3. Gritstone, gray to yellow, earthy, discontinuous, undulating on lower surface, crowded with fish remains on its lower surface ............

English River

2. Gritstone, reddish in top, gray to blue in lower part, very massive,

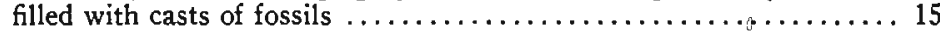

Maple Mill

1. Shale, blue to gray, soft, unctuous, unfossiliferous, filled with lumps of pyrite

Section Exposed at the Wassonville Mill

10. Dolomite, brown, earthy, weathered to a powder, containing fragmented chert and a few large crinoid stems .................. 10

9. Chert, white, nodular, discontinuous, filled with crinoid stems and

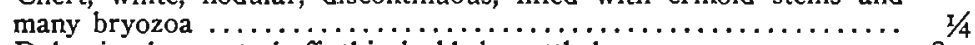

8. Dolomite, brown to buff, thin-bedded, mottled ..................... 8

7. Chert, white, nodular, discontinuous, very fossiliferous, filled with Productus arcuatus ................................... $1 / 2$

6. Dolomite, brown to buff, very massive ........................ $4^{1 / 2}$

5. Chert, white, nodular, discontinuous, very fossiliferous, filled with Chonetes multicostata and many molluscs ................... $1 / 2$

4. Dolomite, brown to buff, mixed with brown shale, lower ledge mas-

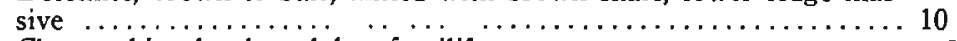

3. Chert, white, hard, nodular, fossiliferous ......................... $1 / 2$

2. Dolomite, brown to buff, mixed with gray English River material .. 4

English River

1. Gritstone, gray to blue, thin-bedded, filled with casts of fossils ..... 10 


\section{The North-Central Iowa Province INTRODUCTION}

The Kinderhook of the north-central Iowa province has a considerably different development from that in the southeastern part of the state. The lower portion of the Kinderhook, including the Sweetland Creek, the Maple Mill and the English River formations, is missing in the great part of the northern province.

\section{DISTRIBUTION AND THICKNESS}

The entire development of the Kinderhook in the northern province may be assigned to the Hampton formation, with the exception of one small exposure of the English River formation in the southern part of the province in Marshall county.

The Hampton formation reaches a much greater development in the northern central area than in the southeastern part of the state. Its maximum thickness reaches as much as 275 feet. The lower parts of this formation in north-central Iowa correspond roughly to the Hampton of the southeastern province, but the upper part of the Hampton is not represented in the southeastern province.

A complete section of the Hampton formation may not be seen at any one place in the northern province. The lower part is best exposed in Franklin county along Maynes creek, south of Hampton, and the upper members of the formation may be seen along Iowa river in Hardin county, between Eagle City and Alden. By visiting these two localities a complete section of the formation may be seen. Exposures of the Hampton formation may also be seen in the southwest corner of Butler county. The greater part of the western half of Grundy county is underlain by rocks that belong to the Hampton formation, but these are almost entirely obscured by the drift. In the eastern part of Marshall county along Iowa river very good exposures of the lower beds of the formation may be seen.

\section{LITHOLOGIC CHARACTER}

The basal member of the Kinderhook of the north-central province consists of hard gray thin bedded fossiliferous limestone that resembles very much the lower gray ledges of the Chouteau at Newark, Missouri. 
This basal member contains in its upper part an oölitic member which is occasionally replaced by dolomite.

The next member in the section consists of soft yellow to brown dolomite layers interbedded with much hard flinty chert. This chert is usually white but is occasionally yellow or even black. This member is fairly massive at the base and is more thinly bedded towards the top. The chert bands also are much more numerous near the top.

This cherty dolomite member is followed by a third member, which consists of brown banded limestone, oölitic limestone, massive brown dolomite, hard white lithographic limestone and hard gray oölitic limestone. This third member is very variable in character.

The upper member is of hard massive brown dolomite at the base and thin-bedded dolomite at the top.

\section{STRUCTURE}

The Kinderhook rocks of north-central Iowa are essentially horizontal strata. They dip to the southwest with very low slopes that average about 12 feet per mile. Insignificant minor folds are occasionally to be seen alorig the faces of exposures.

The belt of outcrop is determined roughly by this gentle dip to the southwest. The exposures are mainly limited to the valley walls of the streams, although in Franklin county in a few places the Iowan drift is thin enough to reflect the underlying surface. In this region numerous exposures occur at the tops of the hills as well as in the valley walls of the streams. The exposures are limited on the west by the terminal moraine of the Wisconsin glacier, which obscures practically all bed rock of the region which it covers.

\section{DIVISIONS}

With the exception of the exposures of the English River in Marshall and Tama counties, the Kinderhook of the north-central province may all be referred to one formation, in which no large stratigraphic breaks are seen. The fauna carries on through the entire formation with no more striking changes than may be expected within a formation.

In 1922 Van Tuyl ${ }^{18}$ divided the northern Kinderhook into six members, the lower of which he called the Sheffield. The Sheffield has now been raised to the rank of formation and correlated with the Chemung

18 Van Tuyl, Iowa Geol. Survey, Vol. XXX, p. 91, 1922. 


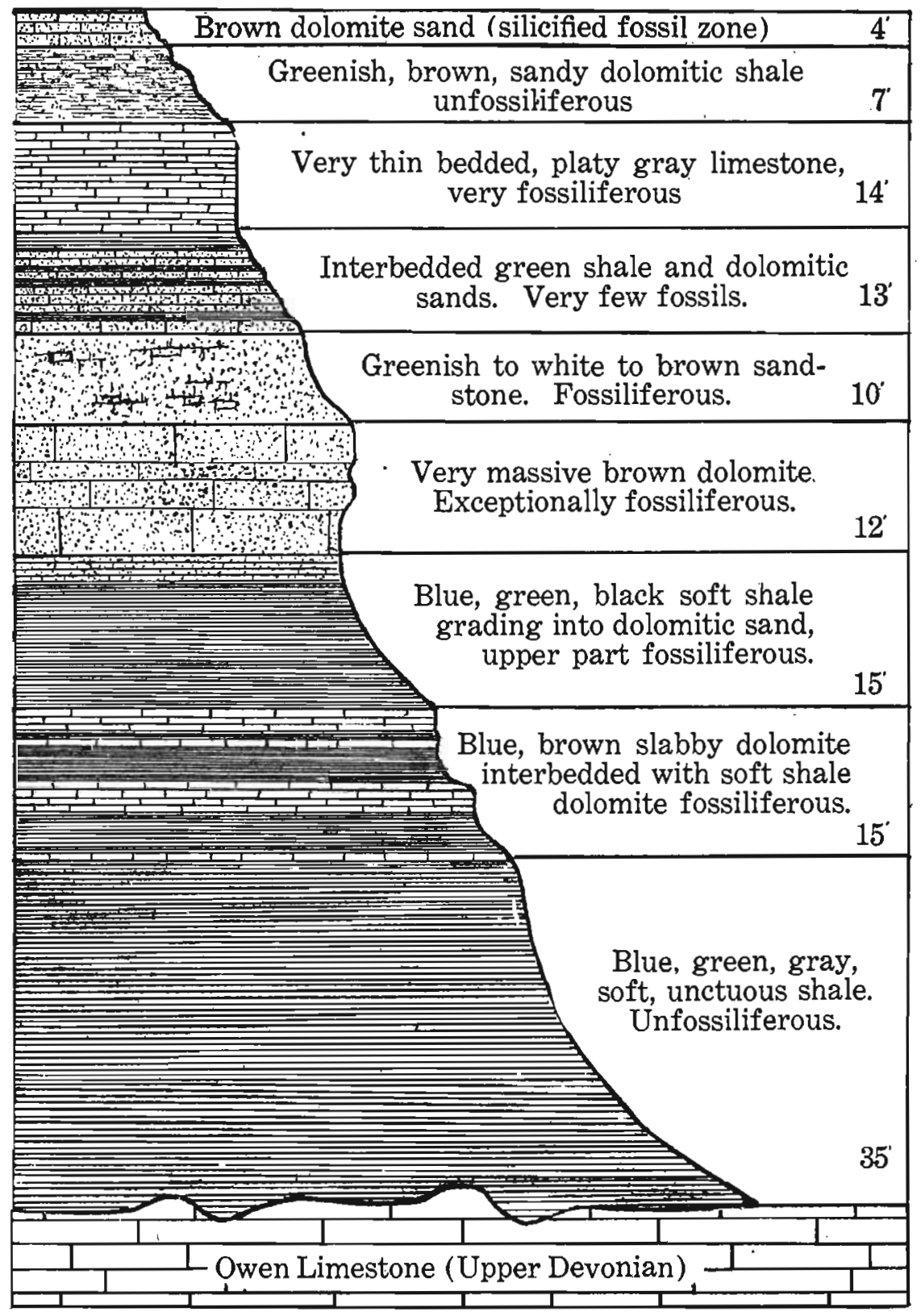

Fig. 51.-Composite Sheffield section as exposed in Franklin county, north-central Iowa. 
of New York, which places it in the Upper Devonian. The upper member of the Kinderhook was called the Alden by Van Tuyl. This member has been correlated with the oölitic limestones of Humboldt and Pocahontas counties and is not considered in this paper as Kinderhook. The other members are retained as Van Tuyl used them except for some slight changes in their boundaries.

\section{GENERAL RELATIONS}

The Hampton formation lies unconformably upon the Sheffield formation. The Hampton in turn lies unconformably beneath the Alden limestone. There are apparently no beds in the north-central area that may be referred to the Osage. The Burlington limestone is known to pinch out long before it reaches the southern boundary of the province. It seems very likely, however, that much of the material found in the upper members of the Hampton has no equivalent in the Chouteau of Missouri. These upper members are very likely much younger than the latest beds of Chouteau age in Missouri.

\section{THE HAMPTON FORMATION}

This name has been proposed for the Kinderhook limestone series exposed in north-central Iowa between the Sheffield formation below and the Alden limestone above. The name Hampton is derived from the city of Hampton, which is the county seat of Franklin county, in which the formation is best exposed. The Hampton formation is divided into four members, the Chapin, the Maynes Creek, the Eagle City and the Iowa Falls, the names of which were proposed by Van Tuyl. ${ }^{18}$

\section{The Chapin Member}

As originally defined the Chapin member consisted of about seven feet of brownish oölitic limestone at the base and about eight feet of exceptionally fossiliferous brown dolomite and chert above. The member was described from the Chapin quarry located one mile west of the town of Chapin, in Franklin county. The member at this place rests on the Sheffield formation. Van Tuyl considered this to be the basal part of this limestone series.

Owing to the unconformity at the contact between the Chapin and the Sheffield formation considerable thicknesses of limestone are found in certain places beneath the oölitic member that was originally defined

19 Van Tuyl, Iowa Geol. Survey, Vol. XXX, p. 91, 1922. 


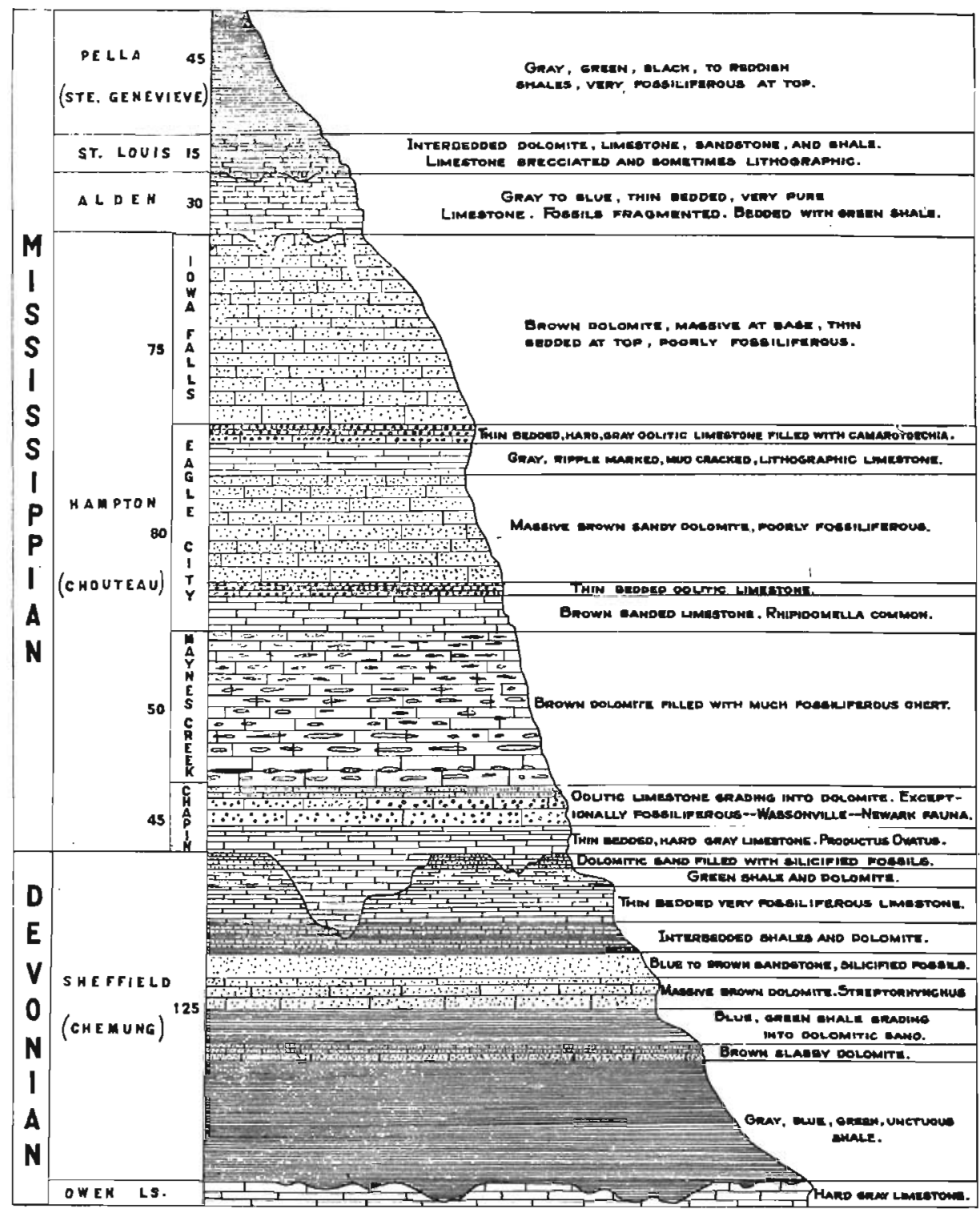

FIG. 52.-Mississippian section of north-central lowa.

as the base. On Maynes creek to the south of Hampton this limestone reaches a thickness of at least 30 feet.

The fossiliferous brown dolomite that is found in the upper part of the Chapin member as described by Van Tuyl is placed in the base 
of the Maynes Creek member for these reasons: lithologically and faunally it is almost identical with the overlying Maynes Creek member; it carries the typical Wassonville fauna that marks the base of the Wassonville member in the southeastern province, which is also a dolomite filled with fossiliferous chert; the oölitic limestone member that underlies it is faunally and lithologically like the oolitic limestone that caps the top of the North Hill member in the southeastern province; the gray limestone that forms the base of the member corresponds to the lower part of the North Hill member of the southeastern province; it is a natural break between hard gray limestones beneath and brown chert-filled dolomite above. This makes possible a correlation of member with member.

The oölitic limestone, then, is considered as the top of the Chapin member. It is locally dolomitized but it is always easily separable from the overlying cherty dolomite.

Distribution and Thickness.-The Chapin member is best exposed in Franklin county. The complete section of this member may be worked out only by zone stratigraphy, but at no place in the county may the complete thickness of the member be seen in one section. The maximum section is developed on Maynes creek, which flows through Reeve and Geneva townships, and at all other places only the upper part of the member is exposed. By following Maynes creek from section 14, Geneva township, where the basal portion is exposed, to section 21, Reeve township, where the upper oölitic member is exposed, a complete section may be seen.

The upper oölitic zone is well exposed in the quarry one mile west of the town of Chapin. This quarry is located in the southwest corner of section 29, Ross township. The same zone may be seen in the abandoned quarries at 13 , section 24, Mott township.

Several small exposures that probably should be referred to the upper oölitic zone may be seen underlying the Maynes Creek member in the southwestern part of Butler county. The latter exposures are usually very dolomitic and are not fossiliferous.

The member is not seen again until one reaches the southern portion of the province in Marshall county. It comes up to the drift the entire distance across Grundy county but is not exposed at any place. In the Iowa river valley near the town of LeGrand, in the eastern part of Marshall county, and in the adjoining part of Tama county the oölitic 


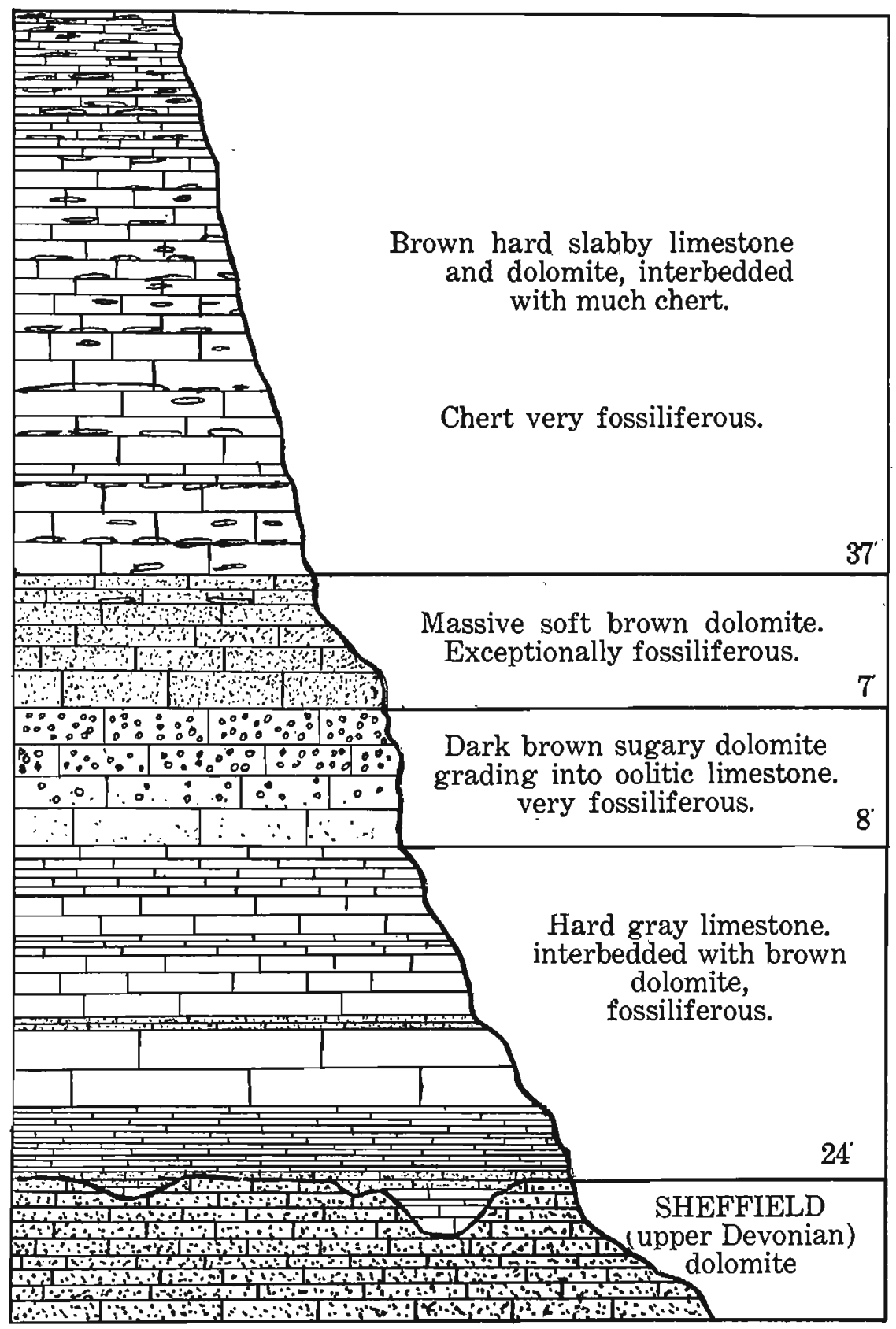

Frc. 53.-Composite section of the Chapin and Maynes Creek members. The upper two groups of beds are referred to the Maynes Creek member. 
member is again exposed. At the base of the section, resting unconformably on the English River gritstone, may be seen about 18 feet of hard gray fossiliferous oölitic limestone. This represents the southernmost exposure of the member in the northern province.

The thickness of the member differs by large amounts in short distances because of the unconformable surface on which it rests. In Franklin county it ranges from 45 feet as a maximum to about eight feet at its thinnest development in the Chapin quarry.

Lithologic Character.--Lithologically the member is not a unit although it is almost entirely made up of limestones. The zones within the member are fairly constant with the exception of the upper oollitic portion. It is in places changed to a sugary dark brown dolomite.

\section{Description of the Zones of the Chapin Member}

Productus ovatus zone.-The basal zone of the Chapin member is exposed in only one place in the north-central province and marks the lowest portion of the Hampton formation. It consists of about eight feet of very hard gray even-textured fossiliferous limestone layers which resemble the material at the base of the Chouteau section at Newark, Missouri. The limestone is very hard and therefore forms resistant ledges throughout the small area in which it is exposed, that is. in several places throughout the southern half of section 14, Geneva township, notably on the tops of the hills in this area. The drift is so thin that in almost every field the blocks and slabs of this material have been scattered over the surface by cultivation.

Streptorhynchus tenuicostatum zone.-This zone exhibits some lithological variations within itself. It is all of a gray color, however, and is made up entirely of limestone. The basal portion of the zone is made up of very thin beds of hard gray fossiliferous limestone; the central portion consists of alternating layers of the same thin-bedded hard gray limestone and more massive beds of lighter gray limestone that are usually much less fossiliferous; and the upper portion again comprises a series of thin beds. Its dominant color is gray, but many of the beds have considerable amounts of brown dolomitic material in them and the upper layers contain considerable chert. This upper portion is usually rather poorly fossiliferous. The zone is about 25 feet in thickness, and it may be best seen at 69 of section 22, Reeve township. four miles south of Hampton. 
Cyathaxonia arcuatus zone.-This zone consists usually of massive hard fossiliferous brown dolomite ledges. In the Chapin quarry, however, it has a tendency to be gray hard oölitic limestone. Where it is oölitic it is easily separated from the overlying dolomitic Maynes Creek member, but when it has been dolomitized its determination is rather difficult without the aid of fossils. It differs from the Maynes Creek in that it is never intercalated with chert bands and is much less fossiliferous. Its ledges are usually much more massive, have a peculiar sugary texture and have a deep chocolate brown color. This zone is best seen in the Chapin quarry one mile west of Chapin, in the southwest corner of section 29, Ross township. Its dolonitic phase may be well studied in an abandoned quarry in the northeast corner of section 23, Mott township.

Paleontology.-The fauna of the basal or Productus ovatus zone is not particularly large, but certain species are very abundant throughout. The zone has local distribution hence it is not possible to say how well it retains its faunal unity. Fossils were collected from several exposures in the southern half of section 14, Geneva township, and one very good exposure may be seen on either side of the north-south road about 500 feet south of the center of this section.

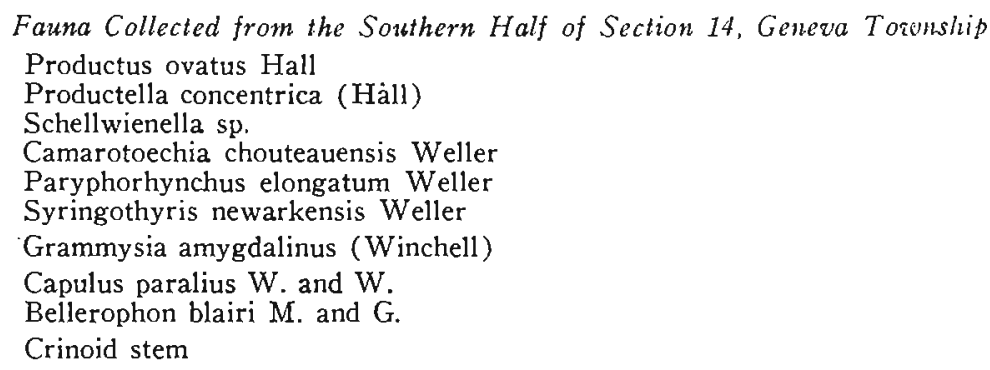

The zone is especially characterized by the great number of individuals of Productus ovatus. This species is not a good index fossil ordinarily because of its long range in the Mississippian. In this particular region, however, it serves very effectively to distinguish the zone. At no other place in the province are large, well preserved individuals found in such abundance.

The fauna of the Streptorhynchus zone is considerably larger than that of the underlying zone. Two species, Streptorhynchus temicostatum and Spirifer biplicoides, may be seen on every slab taken from the thin-bedded limestones. The upper part of the zone is not exception- 
ally fossiliferous, but collections were made from this horizon at several places along Maynes creek. The best exposure may be seen on the south bank of the creek a short distance upstream from the wagon bridge at 69 of section 22, Reeve township.

The lower part of the zone is well exposed on the south bank of Maynes creek, just downstream from the wagon bridge that crosses the creek at 98 , section 14 , Reeve township.

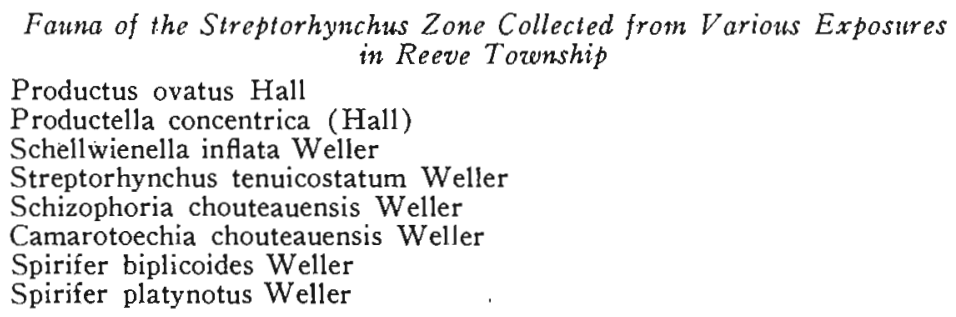

The fauna of the Cyathaxonia arcuatus zone has been listed by Van Tuyl $^{20}$ and a large number of species has been added to his list in this report. Two species, Cyathaxonia arcuatus and Rhipidomella tenuicostata, are very abundant in the zone. The gray limestones are fossiliferous throughout, but the upper layers contain by far the greater part of the fauna.

\section{Fauna of the Cyathaxonia Zone}

(Species marked * were listed by Van Tuyl)

Zaphrentis cliffordana $\mathrm{E}$. and $\mathrm{H}$.

Cyathaxonia arcuatus Weller

Amplexus sp.

Zaphrentis calceola (W. and W.)*

Syringopora sp.

Leptopora typa Winchell

Schizoblastus roemeri (Shumard)

Platycrinus sp.

Leptaena analoga (Phillips)

Chonetes multicostata Winchell

Chonetes logani N. and P.*

Productus arcuatus Hall*

Productus ovatus Hall

Productella concentrica (Hall)

Schellwienella sp.

Schizophoria chouteauensis Weller*

Rhipidomella tenuicostata Weller

Cranaena occidentalis (Miller)

Spiriferina solidirostris (White*)

Spirifer forbesi $N$. and P.*

Spirifer legrandensis Rowley*

Spirifer platynotus Weller*

Spirifer missouriensis Swallow

Syringothyris newarkensis Weller

20 Van Tuyl, lowa Geol. Survey, Vol. XXX, p. 105, 1922 
Brachythyris chouteauensis Weller

Athyris crassicardinalis White

Nucleospira barrisi White

Fenestella sp.

Straparollus obtusus (Hall)

Stratigraphy.-The Chapin member lies unconformably on the Sheffield formation throughout the province. Exposures in which the actual contact may be seen are rather few in the region because of the soft nature of the underlying Sheffield formation. In the northern part of Franklin county the upper oölitic zone rests directly on the Sheffield formation. This relation is seen also on Hartgraves creek just east of the city of Hampton. However, when the valley of Maynes creek, to the southeast of Hampton, is reached the lower horizons may be seen. The lowermost beds of the Productus ovatus zone are in contact with the Sheffield formation on the south side of the east-west road that runs through the center of section 14, Geneva township, just west of the eastern section line.

In Butler county the actual contact between the two formations is not exposed, and it is doubtful if any part of the Chapin member is present there. The dolomitic Maynes Creek member may be seen in one place and a short distance down Beaver creek the upper dolomites of the Sheffield formation are exposed.

In the extreme southern part of the province this disconformity is exposed again in the contact between the English River gritstone and the Hampton formation which may be seen near LeGrand.

The contact between the Chapin member and the overlying Maynes Creek member is usually marked by an abrupt change in lithology. The gray limestones of the Chapin are replaced immediately by soft massive brown exceptionally fossiliferous ledges of dolomite. At a few places the upper part of the Chapin member has been dolomitized and here the two members grade into each other. The Maynes Creek member, like its equivalent, the Wassonville member, is characterized by its chert bands.

Correlations.-The Chapin member seems to be nearly the exact equivalent of the North Hill member of the southeastern Province, although it is highly probable that the Productus arcuatus zone is older than any part of the North Hill member at Burlington. Of the 30 species found in the Chapin member 15 are found in the North Hill member. The Cyathaxonia arcuatus or oölitic zone is apparently the 
equivalent of the oölitic limestone at the base of the section at LeGrand and is also the equivalent of the oollitic limestone or Schellwienella zone at Burlington.

The fauna is closely related to that of the Chouteau of Missouri, especially as that fauna is developed in northeastern Missouri.. Of the 30 species found in the Chapin member 25 are found in the Chouteau. On the basis of this faunal similarity it seems safe to correlate the Chapin member with the Chouteau of northeastern Missouri. The thickness of the Chapin is slightly greater than that of the Chouteau at Newark.

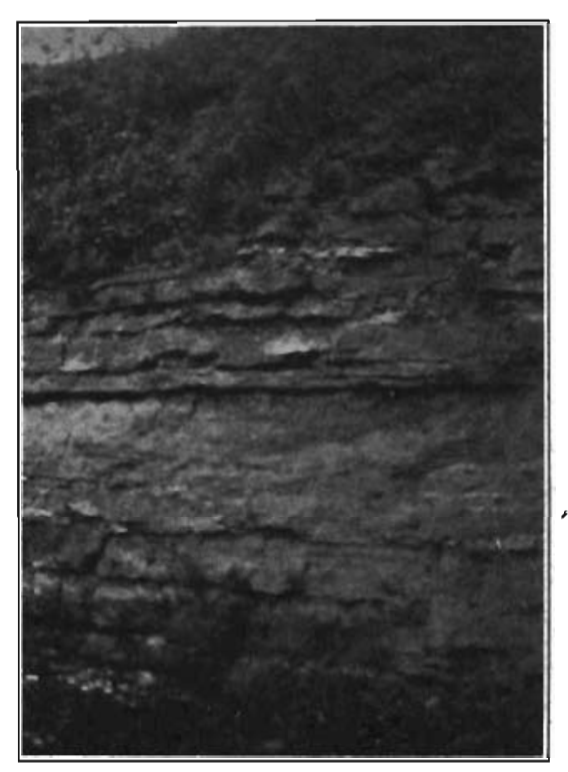

Fig. 54.-Maynes Creek member at Hampton, showing typical chert bands.

The Maynes Creek Member

The term Maynes Creek was introduced by Van Tuyl ${ }^{21}$ in 1922. In it he included 68 feet of brownish fossiliferous dolomite beds interbedded with chert and lying above the dolomite of the Chapin quarry. The type section was located on Maynes creek. The maximum exposure of this member on this creek is located in the northeast corner of section 21, Reeve township, where 41 feet of brown cherty dolomite rests on the upper zone of the Chapin member.

Van Tuyl did not exactly define either the upper or lower limits of the Maynes Creek member. The basal zone of the Maynes Creek as

21 Van Tuyl, F. M., Iowa Geol. Survey, Vol. XXX, p. 91, 1922. 
defined in this paper was included by Van Tuyl in the Chapin. Several large exposures on Maynes creek in Geneva township which belong mainly to the Streptorhynchus zone of the Chapin were referred by Van Tuyl to the Maynes Creek.

The Maynes Creek member is here redefined to include all of the cherty brown dolomitic limestone above the oolitic limestone of the Chapin member and below the banded brown limestone ledges constituting the Rhipidomella zone of the Eagle City member. This includes in the Maynes Creek nine feet of cherty brown dolomite that was placed in the Chapin by Van Tuyl and excludes the gray limestones that are found on the lower part of Maynes creek, which apparently belong to the Chapin member. This member at its maximum is only 50 feet thick.

Distribution and thickness. - The basal ledges of the Maynes Creek member form one of the most widespread zones of the Hampton formation. This lower zone, containing the Wassonville-Maynes Creek fauna, may be traced almost continuously across the state. The upper portions of the member are exposed throughout the northern province but are not developed in the southeastern province.

The northernmost exposures of the Maynes Creek formation may be seen in the quarry one mile west of the town of Chapin, in Franklin county. This exposure marks the northernmost outcropping of the Kinderhook in Iowa. The Maynes Creek is also very well exposed along Spring creek in the northwest quarter of section 1, Marion township, and numerous exposures may be seen along Otter creek throughout Mott township.

The best exposures in the region are seen along the south bank of Spring creek in the city of Hampton, where several quarries have been opened. Only the central part of the member is exposed in these abandoned quarries. The upper part of the member is exposed farther up the same creek, however, in the northwest quarter of section 20 , Mott township.

The member is well exposed on the upper reaches of Maynes creek in the northwest quarter of section 21, Reeve township. This is the exposure that was designated by Van Tuyl as the type section. Numerous small exposures of the member may be seen along the eastern border of Geneva and Osceola townships, and some good exposures are found a few miles north of the city of Ackley and to the 
east just across the Butler county line. The lower part of the member is well exposed along the banks of Beaver creek in Butler county in sections 31, 32 and 28 of Washington township. South of Butler county the member is concealed beneath the drift until Marshall county is reached, where a complete section may be seen.

The thickness of the member is rather constant throughout the region, and its maximum may be considered as 50 feet. At no one section in the northern part of the province may the entire thickness of the member be seen.

Lithologic character.-Lithologically the Maynes Creek member is a unit throughout the province. The lithologic character of the Wassonville member of the southeastern province, with which the Maynes Creek is correlated, is the same. The member consists of massive rather soft dark brown dolomitic layers interbedded with numerous bands of white, gray, or, in places, black chert. These chert bands may be continuous over considerable areas or may be in the form of discontinuous nodules. The chert bands are much more abundant in the upper part of the member and consequently the dolomite is much less massive towards the top.

The dolomite consists of many complete rhombohedral crystals, which are dominantly of the siit size, cemented with calcite and limonite. The solubility runs between 85 and 90 per cent. On fresh surfaces the material has more the appearance of brown limestone, but on weathered surfaces it turns to a soft incoherent sand composed of small rhombohedrons of dolomite.

Both the dolomites and the cherts are filled with fossils. Occasionally the chert nodules weather to a soft incoherent body of white powder, and in this case the imbedded fossils are very easily obtainable.

Paleontology. - The Maynes Creek member has been divided into life zones based on associations of fossils, and these zones have been named for the more abundant species which occur in them. Lithology helps only slightly in the differentiation of the zones.

Productus sedaliensis zone.-This zone forms the base of the Maynes Creek member. It consists of about ten feet of massive soft brown dolomite layers in which very little chert is found. This zone contains by far the most abundant fauna of the Maynes Creek member and is the zone from which the main part of the Hampton fauna has been taken. The fossils occur only as casts and moulds in the dolomite 
and are so abundant that a block six inches in diameter will often yield twenty-five species.

There are several species that might well be used to designate the zone. Productus sedaliensis occurs profusely in the zone but is not necessarily the most abundant species. It is used here because it is less abundant in the zone below and does not occur in the overlying zone. Other species such as Syringothyris newarkensis, Rhipidomella tenuicostata, Leptaena analoga, Spiriferina solidirostris, a species of Aorocrimus, a new species of Spirifer, or a new species of Brachythyris might very well be used to designate the zone.

Fossils from this zone were first listed by Van Tuyl ${ }^{22}$ in 1922 . The following list was made at the abandoned quarry a mile west of Chapin, in Franklin county. This exposure should be considered as the type exposure of this zone, since the fauna is best developed and best preserved at this locality.

(Species marked * were listed by Van Tuyl)

Zaphrentis cliffordana $\mathrm{E}$. and $\mathrm{H}$.

Aorocrinus sp.

Cactocrinus sp.

Platycrinus sp.

Cystodictya sp.*

Fenestella sp.*

Orbiculoidea varsoviensis Worthen

Leptaena analoga (Phillips)

Schellwienella crenulicostata Weller

Schellwienella inflata (W. and W.)

Chonetes illinoisensis Worthen

Chonetes glenparkensis Weller

Chonetes logani $N$. and $P$.

Chonetes sp.

Productus ovatus Hall

Productus arcuatus Hall*

Productus sedaliensis Weller

Productus sp.

Productella concentrica Hall

Rhipidomella tenuicostata Weller

Schizophoria chouteauensis Weller

Camarotoechia chouteauensis Weller

Cranaena occidentalis (Miller)

Dielasma chouteauensis Weller

Dielasma burlingtonensis (White)

Dielasma sp.

Spiriferina solidirostris (White)

Spiriferina subtexta (W.hite)

Spiriferina sp.

Spirifer stratiformis Meek

Spirifer platynotus Weller

Spirifer biplicoides Weller

Spirifer legrandensis Rowley

$22 \operatorname{Van}$ Tuyl, F. M., Iowa Geol. Survey, Vol. XXX, p. 105, 1922. 
Spirifer missouriensis Swallow

Spirifer louisianensis Weller

Spirifer gregeri Weller

Spirifer marshallensis Weller

Spirifer sp.

Brachythyris chouteauensis Weller

Brachythyris sp.

Syringothyris newarkensis Weller

Reticularia cooperensis (Swallow)

Cliothyridina sp.

Eumetria osagensis (Swallow)

Camarophorella lenticularis White

Nucleospira barrisi White

Liopteria subovata M. and G.

Posidonomya sp.

Conocardium sp.*

Cypricardinia sulcifera (Winchell)

Capulus vomerium (Winchell)

Capulus paralius $W$. and $W$.

Igoceras undata Winchell

Conularia sp.

Griffithides sp.

Proetus sp.

The Productus sedaliensis fauna may be identified at numerous exposures throughout Franklin county; and fossil lists will be given from one or two of the more important exposures.

The fauna of this zone is very well developed in an exposure in the northwest corner of section 24, Mott township. This exposure is in an abandoned quarry about three miles to the northeast of the city of Hampton.

Zaphrentis cliffordana $\mathrm{E}$. and $\mathrm{H}$.

Zaphrentis sp.

Fenestella sp.

Cystodictya sp.

Leptaena analoga (Phillips)

Productus sedaliensis Weller

Productus sp.

Rhipidomella tenuicostata Weller

Schizophoria chouteauensis Weller

Cranaena occidentalis (Miller)

Dielasma sp.

Cyrtina sp.

Spiriferina solidirostris (White)

Spirifer biplicoides Weller

Spirifer legrandensis Rowley

Spirifer platynotus Weller

Spirifer missouriensis Swallow

Spirifer sp.

Eumetria osagensis (Swallow)

Camarophorella lenticularis White

Nucleospira barrisi White

Capulus vomerium (Winchell)

Conularia sp. 
The Productus zone is also very well exposed along Beaver creek in the southwest part of Butler county. Numerous exposures of the zone may be seen along the valley walls of the creek in sections 31,32 and 28 of Washington township.

The following fossils were collected from a natural exposure on the south bank of Beaver creek at 43 of section 32, Washington township.

Zaphrentis cliffordana $\mathrm{E}$. and $\mathrm{H}$.

Aorocrinus sp.

Cactocrinus sp.

Platycrinus sp.

Fenestella sp.

Chonetes glenparkensis Weller

Schizophoria chouteauensis Weller

Rhipidomella tenuicostata Weller

Camarotoechia chouteauensis Weller

Paryphorhynchus elongatum Weller

Spiriferina solidirostris (White)

Spiriferina subtexta (White)

Spirifer platynotus Weller

Spirifer missouriensis Swallow

Spirifer striatiformis Meek

Spirifer biplicoides Weller

Spirifer legrandensis Rowley

Spirifer sp.

Spirifer sp.

Syringothyris newarkensis Weller

Brachythyris chouteauensis Weller

Brachythyris sp.

Camarophorella lenticularis White

Athyris crassicardinalis White

Capulus paralius $W$. and $W$.

Bellerophon blairi $M$. and $G$.

Proetus sp.

Chonetes multicostata zone. - This zone forms the central and main part of the Maynes Creek member. It consists of 25 feet of brown dolomite layers interbedded with numerous bands of gray and white chert. The lower portion of the zone is more massive than the upper portion.

It is in the chert bands that the typical Wassonville-Maynes Creek fauna is found. Most of this chert is very hard and resistant, but at a few horizons is found weathered chert that is filled with fossils. The harder chert bands are filled with fossils also, but it is very difficult to obtain satisfactory material from them. The same fauna is found in the dolomite but occurs only as casts and moulds.

Chonetes multicostata occurs most abundantly in the lower part of the zone. Masses of chert taken from these lower bands are crammed with specimens of this species. These chert masses filled with 
Chonetes are found throughout the entire belt of outcrop of the Hampton formation in the state.

Fossils were listed by Van Tuyl in 1922 from this horizon in the northern province. He collected an abundant fauna from the type section of the member on the north bank of Maynes creek in the northwest corner of section 21, Reeve township. At this exposure the cherts are much weathered and the fauna is readily collected. The weathered part at this exposure is only about twelve feet above the bed of the stream.

Fauna from the Type Section

(Species marked * were listed by Van Tuyl)

Zaphrentis cliffordana $\mathrm{E}$. and $\mathrm{H}$.

Cystodictya sp.

Orthotetes sp.*

Chonetes multicostata Winchell

Chonetes illinoisensis Worthen

Chonetes logani $N$. and $P$.

Productus ovatus Hall

Productella concentrica (Hall)

Camarotoechia chouteauensis Weller

Camarotoechia tuta (Miller)

Spiriferina solidirostris (White*)

Spirifer legrandensis Weller*

Spirifer platynotus Weller

Nucleospira barrisi White.

Tigeria sp.

Leda saccata Winchell*

Myalina sp.**

Liopteria subovata $M$. and $G$.

Nucula glenparkensis Weller

Nucula iowensis W. and W.

Straparollus macromphalus Winchell

Bellerophon sp.*

Ducanopsis sp.*

Meekospira sp.*

Orthonychia sp.*

Euphemus sp.

Strophostylus bivolve $\mathrm{W}$. and $\mathrm{W}$.

Proetus sp.

Phillipsia sp.*

-In an old quarry on the south bank of Spring creek, in the northern part of the city of Hampton, the cherts of the Chonetes zone are again weathered so that the fauna is easily available. This abandoned quarry exposes the entire section of the zone. The following fauna was collected from the lowermost chert band exposed in the quarry.

Zaphrentis cliffordana $\mathrm{E}$. and $\mathrm{H}$.

Chonetes multicostata Winchell

Chonetes illinoisensis Worthen

Schellwienella inflata (W. and W.)

Schellwienella sp. 
Productella concentrica (Hall)

Camarotoechia chouteauensis Weller

Camarotoechia tuta Miller

Spiriferina solidirostris (White)

Spiriferina subtexta (White)

Spiriferina sp.

Spirifer platynotus Weller

Spirifer biplicoides Weller

Spirifer sp.

Camarophorella lenticularis White

Nucleospira barrisi White

Tigeria sp.

Ptychodesma sp.

Straparollus macromphalus Winchel]

Capulus paralius $W$. and $W$.

Orthoceras indianense Hall

Dentalium grandaevum Winchell

Proetus sp.

The two common species in this zone are Chonetes multicostata and Spirifer platynotus. Both of these species occur throughout this horizon and both of them range in about the same numbers throughout both provinces. The molluscan fauna is not as pronounced in the northern province as it is in the southern.

Spirifer striatiformis zone.-This zone is the uppermost of the Maynes Creek member. It consists of about fifteen feet of thinbedded yellow dolomite beds that contain much less chert than the underlying zone. As a rule these upper beds are not abundantly fossiliferous. At certain places, however, casts of fossils are found preserved in the soft yellow dolomites.

Exposures of this zone are not numerous in the region. It is exposed in the upper part of the valley of Spring creek, northwest of Hampton, and in the upper valley of Maynes creek, south of Hampton. The fossils where present are preserved as casts in the yellow dolomite. This, however, is of so soft a nature that good specimens are difficult to obtain. It is only in the lower layers that occasional casts of fossils are seen.

The most fossiliferous exposures are seen on the upper reaches of Spring creek, northwest of Hampton. The following species were collected from this horizon at 41 of section 20, Mott township. The top of the Chonetes zone may be seen just downstream from the exposure and on the opposite side of the creek.

Zaphrentis cliffordana $\mathrm{E}$. and $\mathrm{H}$.

Platycrinus sp.

Fenestella sp.

Cystodictya sp. 
Schellwienella inaequalis (Hall)

Chonetes sp.

Productus secialiensis Weller

Schizophoria chouteauensis Weller

Spiriferina solidirostris (White)

Spirifer stratiformis Meek

Spirifer platynotus Meek

Brachythyris sp.

Reticularia cooperensis (Swallow)

Proetus sp.

Spirifer striatiformis and Productus sedaliensis occur very abundantly in this zone. The zone may be easily distinguished from the lower zone of the member by the scarcity of fossils.

Stratigraphy.-The Maynes Creek member is separated from the underlying Chapin member only by a slight lithological break. The fauna is directly related to that of the underlying member and continues across the line of contact.

The contact of the Maynes Creek member with the overlying Eagle City member is marked only by a slight lithological break. The rock changes from a soft yellow dolomite to a hard banded crystalline brown limestone which is usually somewhat crinoidal. The contact of the Maynes Creek with the Eagle City is exposed in an abandoned quarry about three and one-half miles north of the city of Ackley, just west of the center of the east line of section 14, Osceola township.

The cherts of the Chonetes multicostata zone form such a widespread horizon in Iowa that they may be used for correlation even in well sections a considerable distance west of the belt of exposure. ${ }^{28}$ In the main city well No. 8 at Fort Dodge in Webster county the Maynes Creek member with its chert zone is present at 430 feet. In this well indurated rock is struck at 150 feet. The shale and limestone from 150 to 210 feet should be referred to the Pella and St. Louis formations. The oölitic light cream-colored limestone bedded with green shale, from 210 to 310 feet, undoubtedly belongs to the Gilmore City formation of Spergen age. The gray and buff limestones and dolomites from 310 to 430 feet represent the Iowa Falls and Eagle City members of the Hampton formation. From 430 to 480 feet are found brown dolomite and gray cherts which probably represent the Maynes Creek and Chapin members of the Hampton formation. From 480 to 540 feet are shales and yellowish limestones before the true Devonian limestone is reached. Because of the calcareous material

23 Norton, W. H., Iowa Geol. Survey, Vol. XXI, 1911; Vol. XXXIII, 1927. 
which they contain it would seem advisable to refer these shales and limestones to the Sheffield formation rather than to the Kinderhook shales.

In wells farther to the west are found cherts that might possibly be referred to this horizon, although such a correlation would be very uncertain. In the Auburn well in Sac county cherts and brown dolomites are found near the base of the Mississippian section, from 710 to 800 feet. In the Audubon well in Audubon county cherty brown limestone overlying oölitic limestone is found from 955 to 1025 feet.

Correlation.-The fauna of the Maynes Creek member is very definitely related to the Chouteau of Missouri. It is either directly equivalent to some part of the Chouteau or is derived from it. Of the 48 species present in the Maynes Creek member 33 are found in the Chouteau at Newark, Missouri, while 28 are found in the Chouteau of central Missouri.

There are 30 species present in the Chapin member and of these 23 range on into the Maynes Creek. All but one of the 19 species found in the Chonetes zone are found in the Wassonville cherts of the southeastern province.

\section{The Eagle City Member}

The term Eagle City was introduced by Van Tuy ${ }^{24}$ in 1922 . As defined by him it included 70 feet of gray limestones and interbedded dolomite, and its upper limits were very definitely determined. The lower contact was not seen by him in the field and was established only from a deep well section.

The basal member of the Eagle City is a brown banded hard crystalline semicrinoidal limestone about 12 feet thick. The upper part consists of six feet of hard gray very fossiliferous oölitic limestone underlain by 12 feet of hard gray lithographic limestone. The Eagle City member is defined as embracing all strata between and including the banded brown limestone at the base and the oölitic limestone at the top. The central portion of the Eagle City is made up of a massive soft yellow dolomite.

Distribution and Thickness.-The Eagle City member has a very limited distribution in Franklin county, and although it is probably present beneath the drift in a belt extending across the entire county it is exposed only in the southeastern part of the county. The terminal

24 Van Tuyi, F. M., Iowa Geol. Survey, Vol. XXX, p. 91, 1922. 
moraine of the Wisconsin glacier extends across Franklin county in such a manner that the preglacial exposures of the Eagle City member come well within its limits and are deeply: buried. This explains the limited number of exposures of the member.

The basal zone of the Eagle City member is exposed in an abandoned quarry about three and one-half miles north of the city of Ackley. This exposure may be seen on either side of the north-south road that runs between sections 13 and 14 of Osceola township. The quarries are located in the west center of section 13 and in the east center of section 14.

The Eagle City formation is not seen again until the valley of Iowa river is reached in Hardin county. Exposures may be seen at many places on either side of Iowa river and in the valleys, of small tributary creeks between Eagle City, in the southwest corner of Aetna township. and Jowa Falls, in Hardin township. The last exposures of the member to the west may be seen in the gorge of Iowa river just below the dam at the power plant at Iowa Falls. The dam is built upon the hard lithographic limestones of the upper part of the Eagle City member.

Below Eagle City on Iowa river the exposures are very poor. A few soft dolomitic ledges have been located but it is not possible to refer them to any particular zone. From Steamboat Rock to Eldora the Kinderhook beds are covered by Pennsylvanian sediments. The first outcrop of the Eagle City may be seen on the left bank of Iowa river about a mile south of Eldora. From here on southward occasional exposures may be seen all the way to Marshall county.

The thickness of the Eagle City member is about 80 feet and may be only approximately measured in the field. Each of the separate zones must be measured alone and at different exposures. The lowermost beds may be seen north of Ackley and the remainder may be seen at a series of sections on Iowa river from Eagle City to Iowa Falls.

Lithologic Character.-The Eagle City consists of four rather definite lithological zones. The lowermost is a hard brown banded crystalline partly crinoidal limestone. The second zone consists of very thin-bedded gray oölitic limestone interbedded with fossiliferous dolomite. The main central zone consists of very massive soft brown dolomite beds that reach a thickness of 42 feet. The upper zone consists of two parts, a lithographic limestone at the base and an oölitic limestone at the top. The lithographic limestone is thin-bedded, gray 


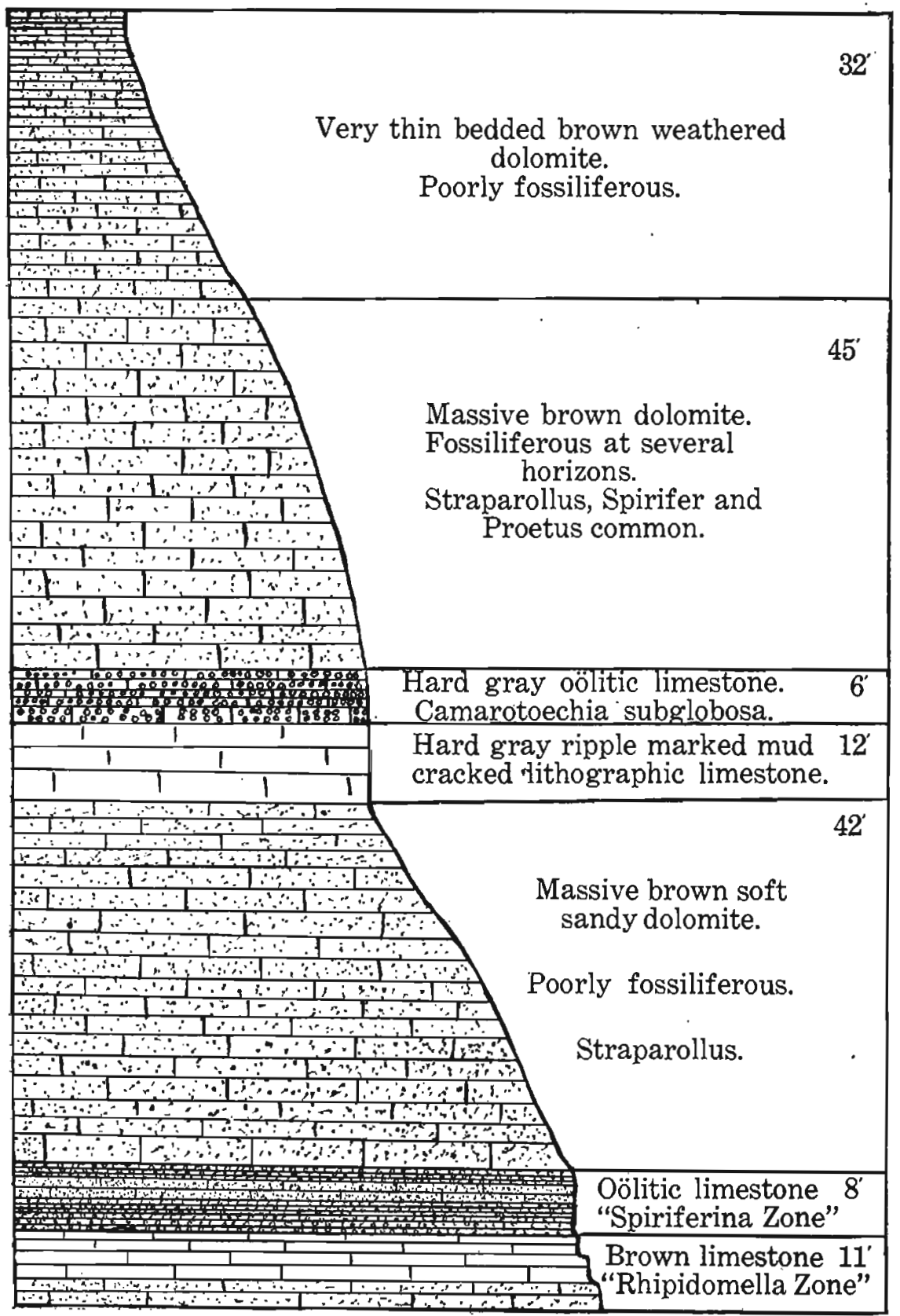

Fic. 55.-Composite section of the Eagle City and Iowa Falls members. The upper two groups of beds are referred to the Iowa Falls. 
and slightly ripple marked. The oölite is gray, thin-bedded and very fossiliferous.

The lower part of the Eagle City member may be traced southward and may be seen with the same lithologic character in Marshall and Tama counties. The upper part is exposed only on Iowa river in Hardin county, hence it is not possible to make statements regarding its lithology in other parts of the state.

Paleontology. - The Eagle City member has been divided into four life zones. These zones in this case correspond more or less closely with the lithologic zones. They are named for the most abundant fossils which they contain, although the fauna is not large at any place.

\section{Life Zones of the Eagle City}

\section{FEET}

4. Camarotoechia subglobosa zone ....................... is

This zone consists of the upper oölitic limestone and the underlying lithographic limestone. The lithographic limestone is almost barren of fossil remains. The upper oölitic part is filled with Camarofoechia subglobosa.

3. Straparollus obtusus zone ........................ 42

This zone is practically barren of fossils in its greater part. In certain of the beds in the upper part of the zone numerous casts of Straparollus obtusus may be found.

2. Spirifer biplicoides zone ......................... 8 This is the most fossiliferous zone of the member. It is named for Spirifer biplicoides, which occurs very abundantly throughout the zone.

1. Rhipidomella burlingtonensis zone ...................... 12 The basal zone is not exceptionally fossiliferous. The banded brown limestone ledges carry a large amount of crinoidal material and numerous specimens of Rhipidomella burlingtonensis.

The Rhipidomella burlingtonensis zone is exposed in only one locality, although an equivalent horizon probably is represented in the section at LeGrand in Marshall county. The zone is exposed three and one-half miles north of Ackley, in Franklin county, in the abandoned quarry in the southwest corner of section 13 and in the southeast corner of section 14 of Oșceola township.

Fauna of the Rhipidomella Zone North of Ackley

Leptaena analoga (Phillips)

Rhipidomella burlingtonensis Hall

Camarotoechia chouteauensis Weller

Spirifer platynotus Weller

Strophostylus bivolve W. and W.

Cactocrinus sp.

Proetus sp.

The Spirifer biplicoides zone outcrops best in the immediate vicinity of the town of Eagle City, in the southwest corner of section 31, Aetna 
township. The type exposure is located in an old quarry on the east bank of Iowa river just south of the highway bridge that crosses the river at this point. The entire thickness of the Spirifer biplicoides zone is exposed at this place, as well as 33 feet of the overlying Straparollus zone. The limestones of the Spirifer biplicoides zone are exposed along the east bank of Iowa river for a considerable distance downstream from this quarry.

Fanna of the Spirifer biplicoides Zone at Eagle City

(Species marked * were listed by Van Tuyl)

Chaetetes sp.*

Rhombopora sp.*

Fenestella sp.*

Leptaena analoga (Phillips)

Schellwienella inflata Weller*

Streptorhynchus tenuicostatum Weller

Chonetes burlingtonensis Weller

Productus blairi Miller

Productus ovatus Hall*

Productus sp.*

Rhipidomella cf. tenuicostata Weller

Schizophoria sp.*

Camarotoechia chouteauensis Weller

Spiriferina subtexta (White*)

Spiriferina solidirostris (White)

Spiriferina sp.

Spirifer latidor Swallow

Spirifer biplicoides Weller

Spirifer missouriensis Swallow

Spirifer calvini Weller

Eumetria osagensis (Swallow)

Eumetria verneuiliana Hall

Reticularia cooperensis (Swallow)

Hustedia circularis (Miller)

Aviculopecten sp.*

Capulus paralius W. and W.

Orthonychia sp.*

Straparollus sp.*

Orthoceras sp.

Proetus sp.

Beds which may be referred to this horizon are found in the southeastern part of Hardin county in the vicinity of Gifford in Union township. A small exposure of gray-brown limestone may be seen in an abandoned quarry on the south bank of the first small creek south of Gifford on the northeast side of the highway at 77 of section 4, Union township. The following fauna was collected from this exposure.

Schellwienelia planumbona Weller

Chonetes logani $\mathrm{N}$. and $\mathrm{P}$.

Camarotoechia chouteauensis Weller

Dielasma chouteauensis Weller

Spiriferina solidirostris White 


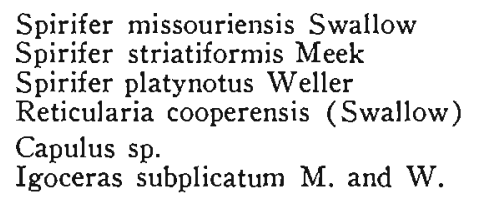

The Straparollus obtusus zone forms the greater part of the Eagle City member. The thick massive beds of dolomite exposed along Iowa river between Eagle City and Iowa Falls belong mainly to this zone, but they are very easily confused with the dolomite ledges of the Iowa Falls member. The relation of the Camarotoechia subglobosa zone to both the Iowa Falls member and the Straparollus zone may be seen in the old quarries along the banks of Iowa river just east of the city of Iowa Falls.

The fauna of the Straparollus zone is very meager. Throughout the greater part of this section no traces of fossils may be found. In the central part of the zone is found a thin bed in which casts of Straparollus obtusus occur abundantly, with a few other species in association with a cyathophylloid corral and a Spirifer. Another layer lower in the section shows numerous stems of a species of Platycrinus. The exact horizon of these beds cannot be determined because the contact of neither the underlying nor the overlying zone is exposed.

Fauna collected from an exposure on the south bank of Iozva river at 189 of section 34, R. 20 W., Trup. $89 \mathrm{~N}$.

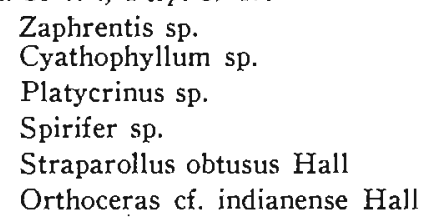

One horizon of the Iowa Falls nember also is filled with casts of Straparollus obtusus. The Iowa Falls horizon may be easily differentiated from this zone by its greater number of fossils and its greater number of species.

The Straparollus zone is again exposed on the right bank of Iowa river one mile south of the city of Eldora. The exposure is about 500 feet downstream from the old highway bridge one mile south of the city. Casts of Straparollus and of a cyathophylloid coral are found abundantly in certain beds of the dolomite.

The Camarotoechia subglobosa zone consists of two parts lithologically, a hard gray lithographic limestone at the base and a thin-bedded 
gray oölitic limestone at the top. Both portions are fossiliferous but the number of species present is very limited. Certain horizons of the upper oölitic part are crowded with Camarotoechia subglobosa. The next most abundant fossil is a slender cyathophylloid coral.

The zone is best exposed in the Ellsworth stone quarry, located on the left bank of Iowa river just southeast of the city of Iowa Falls at 97 of section 18, Hardin township. The entire zone, with both lower and upper contacts, may be seen here. It is also well exposed in another abandoned quarry just across the river from the Ellsworth quarry. A partial section of the lithographic limestone and the entire oölitic part may be seen in the gorge of Iowa river immediately below the dam at the power plant in Iowa Falls. The exposures of this zone are practically limited to a few miles of the gorge of Iowa river.

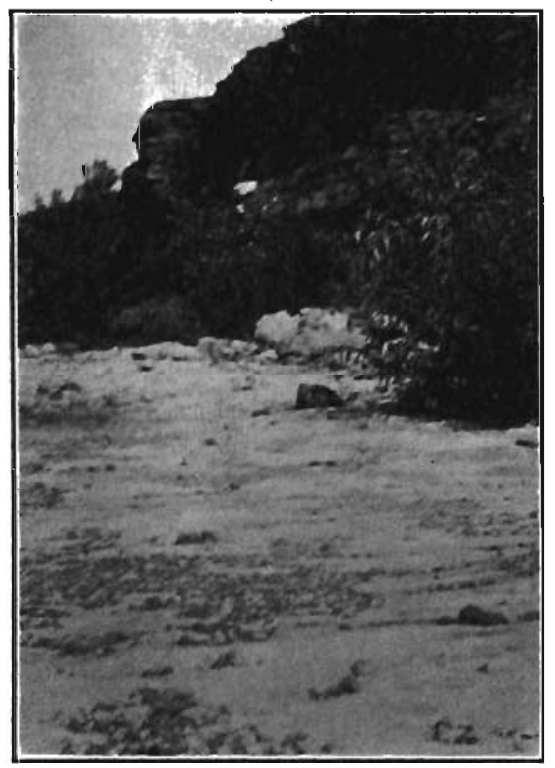

Fig. 56.-Ellsworth Stone Quarry at Iowa Falls. Lithographic limestone forms quarry floor.

Cyathophyllum sp.

Fauna Collected from the Camarotoechia subglobosa Zone (Species marked * were listed by Van Tuyl)

Syringopora sp.

Stromatopora sp.

Streptorhynchus tenuicostatum Weller

Camarotoechia subglobosa Weller

Camarotoechia sp.*

Eumetria verneuiliana Hall

Conocardium sp.*

Schizodus sp.

Schizodus sp.

Straparollus obtusus Hall 
Stratigraphy.-The Eagle City member overlies the Maynes Creek member conformably. The lithologic change from the underlying Maynes Creek dolomite to the brown crystalline limestone ledges of the basal Eagle City is not abrupt. The fauna of the basal Eagle City is definitely related to the Maynes Creek fauna.

The break between the Eagle City member and the overlying Iowa Falls dolomite is sharp, and the gray limestone of the Eagle City ends with knifelike sharpness against the Iowa Falls dolomite. The contact appears irregular and slightly unconformable at all exposures. The lithographic limestone is ripple marked and is undoubtedly of shallow water origin. Oölitic limestone is very likely formed in very shallow water, where the oolites can be intermittently exposed to the air, and such conditions would be found on a tidal flat. The upper surface of the Eagle City is no more uneven than would be expected of a shallow water deposit that had been subjected to the action of waves and shore currents.

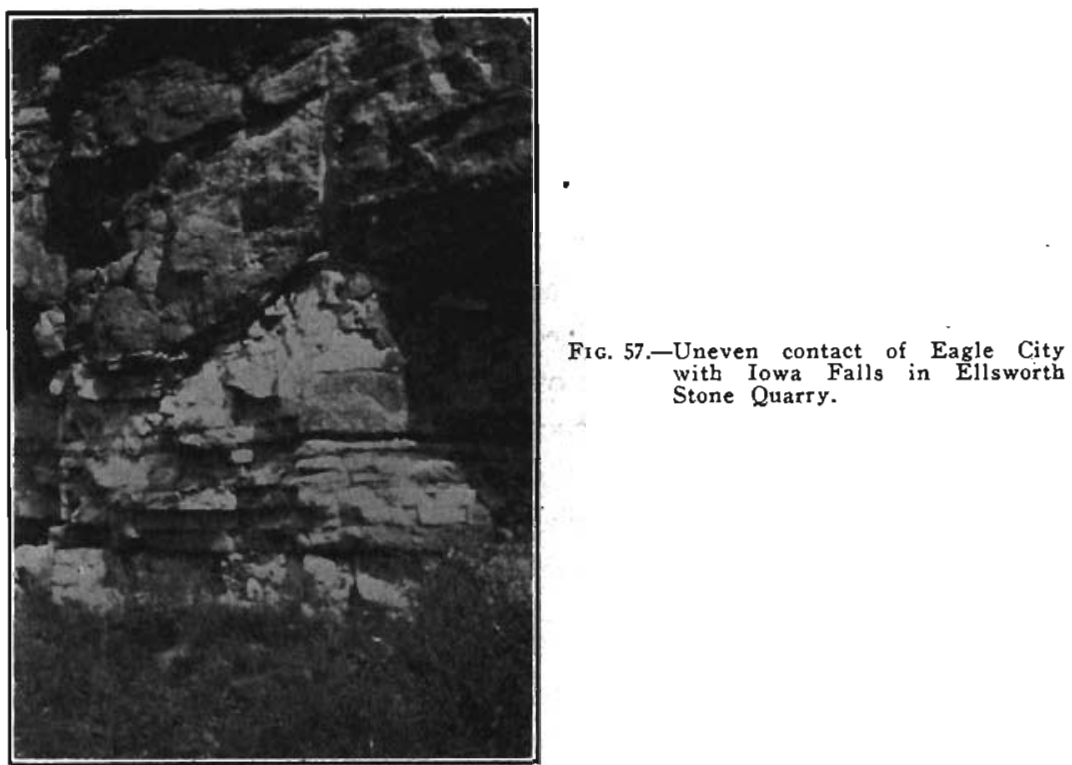

Correlation.-The Eagle City member has a very limited distribution. Exposures of the lower zones of the member may be traced southward as far as Marshall county, as for instance near LeGrand in Marshall county, near Conrad and Beaman in southern Grundy county, and around Gifford and Xenia in southern Hardin county. The 
exposures of the upper part of the zone are confined to Iowa river valley between Eagle City and Iowa Falls.

The fauna of the Eagle City is much smaller than that of the Maynes Creek member but includes many species that undoubtedly were derived from the underlying Maynes Creek. Such forms as Leptaena analoga, Schellwienella inflata, Streptorynchus tenuicostatum, Camarotoechia chouteanensis, Spirifer missouriensis, Spiriferina solidirostris and Spirifer platynotus are highly characteristic of the underlying members of the Hampton formation.

Such forms as Eumetria verneuiliana, Productus blairi, Spirifer latior, Spirifer calvini, Hustedia circularis and Camarotoechia subglobosa are not characteristic of the lower members.

There are 29 species of invertebrates present in the Eagle City member and of these 19 are found in the Chouteau at Newark, Missouri, and 16 are found in the Chouteau of central Missouri. The preponderating part of the fauna seems to be related to the Chouteau of Missouri.

Thirteen species that are found in the Eagle City fauna occur in the Osage formations. Such forms as Camarotoechia subglobosa and Eumetria verneuiliana have never been reported from beds older than the Osage.

The beds of the Eagle City member probably are younger than any of the Chouteau beds of Missouri, but the fauna is definitely derived from the Chouteau fauna. The Eagle City beds are considered to be part of the Hampton formation because their fauna is definitely de- " rived from the Hampton, because of a similarity in lithology with the other members of the Hampton, because of a dissimilarity in lithology between the Eagle City and the Osage beds, and because the Osage beds may be demonstrated to overlap unconformably on the Hampton surface in the southern part of the state.

\section{The Iowa Falls Member}

The term Iowa Falls was introduced by Van Tuyl ${ }^{25}$ in 1922. The Iowa Falls member as defined by Van Tuyl includes all of the dolomite* beds between the oölitic limestone of the Eagle City nember and the white limestone ledges of the Alden formation, which overlies the Iowa Falls unconformably. The Iowa Falls member is used in this paper exactly as defined by Van Tuyl.

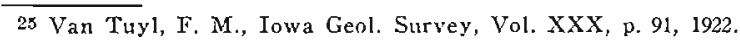


Distribution and Thickness. - The Iowa Falls member has a very local distribution, and its exposures are practically confined to a few miles of the Iowa river valley in Hardin county. It undoubtedly underlies extensive areas of this part of the state but is obscured by the heavy drift.

Exposures of the Iowa Falls member may be seen in the bluffs of Iowa river in section 28 , Hardin township, where they occupy the upper parts of the bluffs. The member gradually is more and more prominent farther upstream towards Iowa Falls and is best exposed within the city limits, in the gorge of Iowa river above the power plant dam. The lower part is very well exposed in the abandoned stone quarries along Iowa river in the southern part of section 28, Hardin township.

The upper beds are well exposed in the western suburb of Iowa Falls, also at "Wild Cat Glen", along the lower end of Elk run, and along the south bank of Iowa river one mile west of the city in section 14, Range 21 West, Township 89 North. The unconformable contact of the Iowa Falls with the Alden is exposed on the south bank of Iowa river at 79 of section 15, Range 21 West, Township 89 North.

The whole thickness of the Iowa Falls member may not be seen in one section, but it is exposed within the distance of a mile. The lower part may be seen in the gorge above the power plant and the upper thin beds at "Wild Cat Glen", which is less than a mile from the gorge section. The thickness of the member is about 75 feet and may be measured only by projecting known zones over considerable distances.

Lithologic character. - The Iowa Falls member is made up entirely of brown dolomite. It is very difficult to locate exact horizons unless the contact of the Eagle City or of the Alden is exposed. The lower beds are very massive with bedding planes as much as four feet apart. Microscopically the dolomite consists of thombohedrons of dolomite that are mainly of the silt size and are cemented with calcite. The upper part of the member consists of very thin beds of harder brown dolomite that is usually lighter in color than the lower part:. The upper surface, on which the Alden rests, as a rule is very much leached and covered with solution pits. Curious nodular-like masses of harder dolomite are left on this leached surface.

Paleontology. - The Iowa Falls is generally considered to be practically unfossiliferous and the majority of the beds appear as such. 
However, at a few localities discontinuous lenses of fossiliferous material have been found.

On the basis of these fossiliferous beds the member has been divided into three zones, but these zones cannot be established with the same definiteness as the zones of the other members of the formation.

\section{Life Zones of the Iowa Falls}

Spirifer platynotus zone.-This zone consists of the basal five feet of the member, and at certain localities fossils occur abundantly in the lower three feet. A large form of Spirifer platynotus which is really a variety of the true $S$. platynotus characterizes these beds. The association with this Spirifer of species that are not found elsewhere in the Hampton definitely establishes the zone.

This zone is exposed in many places near the city of Iowa Falls, but it is only at certain localities that the beds carry fossils. Fossiliferous strata in this horizon may be seen in the old Ellsworth stone quarry on the left bank of Iowa river at 97 of section 18, Hardin township. Fossils may also be collected from this horizon in an old quarry on the left bank of Iowa river about 500 feet downstream from the power plant in Iowa Falls. The following fauna was collected from these two exposures.

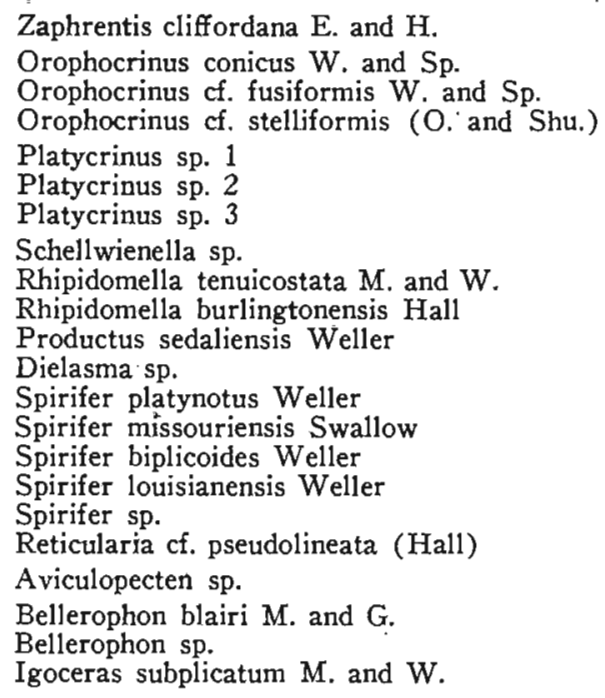

The Loxonema zone.-This zone is named for an undescribed species of Loxonema which occurs abundantly in the horizon. This 
gastropod is a large easily distinguishable form characteristically about three inches in length. The zone contains an association of species that distinguishes it very readily from any other in the Hampton formation. The fossiliferous part of this zone is about three feet in thickness and is located about 18 feet above the contact of the Eagle City with the Iowa Falls. The Loxonema zone is made to include all of the massive dolomite beds above the Spirifer platynotus zone. This excludes the upper thin beds of the member and makes the Loxonema zone about 40 feet in thickness.

The fossil-bearing beds of this zone may best be seen in the old Ellsworth stone quarry southeast of Iowa Falls, where the fossil-bearing bed occupies a band about five feet down from the top of the quarry face. The zone is well exposed also in the two old stone quarries on the opposite side of Iowa river from the Ellsworth quarry.

The most abundant fossil in the fauna is a large form of Straparol lus obtusus which averages at least two inches in width. Three species, the Straparollus, the Loxonema, and a species of Cyathophyllum crowd the horizon. The fossils have been preserved for the most part as casts and moulds in the dolomite, but a few have been replaced by a milky white form of calcite.

Cyathophyllum sp.

Fauna Collected from the Loxonema Zone

Cactocrinus sp.

Bryozoa sp.

Streptorhynchus tenuicostatum Weller

Camarotoechia subglobosa Weller

Spiriferina sp.

Spirifer platynotus Weller

Conocardium sp.

Straparollus obtusus Hall

Platyschisma missouriensis Weller

Orthoceras indianense Hall

Centronelloidea rowleyi zone.-The fossils of this zone were collected and listed by Van Tuyl ${ }^{26}$ in 1922 and have not been seen by the writer. Centronelloidea rozeleyi is chosen as a zone name since it is not a common species in other parts of the Kinderhook of Iowa.

The fossils collected from this zone were found in the upper thin beds at "Wild Cat Glen" in the western suburb of Iowa Falls. The upper thin-bedded material is about 30 feet in thickness and only the lower

26 Van TuyI, F. M., Iowa Geol. Survey, Vol. XXX, p. 98, 1922. 
part of this occurs at "Wild Cat Glen". It is assumed then that these fossils came from the lower part of the zone.

Fauna Listed by Van Tuyl from the Centronelloidea Zone

Zaphrentis sp.

Orthotetes sp.

Dielasma sp.

Camarotoechia cf. tuta (Miller)

Camarotoechia sp. ?

Spiriferina solidirostris (White)

Spirifer sp.

Ambocoelia sp.

Centronelloidea rowleyi (Worthen)

Athyris crassicardinalis White?

Orthonychia sp.

Holopea subconica Winchell?

Stratigraphy.-The Iowa Falls member is separated from the underlying Eagle City member by a sharp lithological break. A discussion of this contact has been given under the stratigraphy of the Eagle City member.

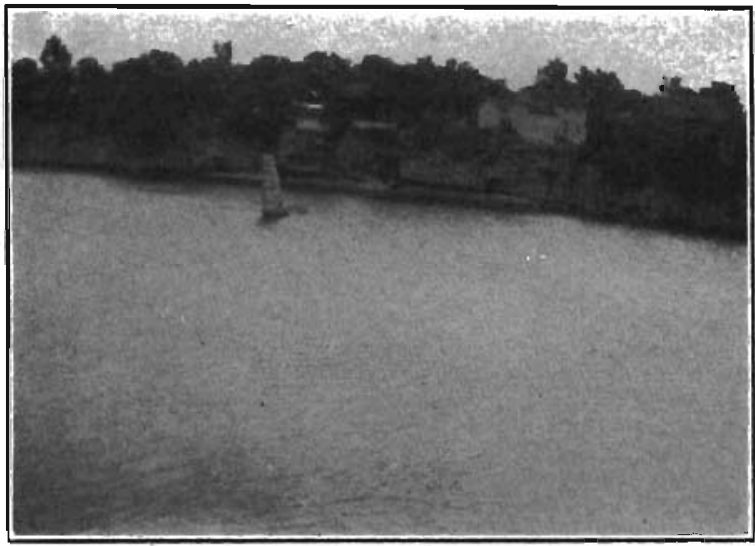

Fig. 58-Small arch showing contact of Eagle City with Iowa Falls above power plant at Iowa Falls.

The Iowa Falls member is unconformably overlain by the Alden limestone, which consists of soft gray to bluish thin-bedded limestone. The Alden is slightly fossiliferous but the fossils are so fragmented that none have been identified. The Alden is correlated with the oölitic limestone which is exposed near Humboldt and Gilmore City farther to the west. The exact age of the fauna of the Gilmore City limestone is doubtful. The crinoid fauna in the base of the formation at Gilmore City contains a great number of Kinderhook genera although almost all of the species are entirely new. It is considered as 
younger than the Kinderhook because of the fauna and because of the marked unconformity which separates it from the upper beds of the Kinderhook. The fauna as a whole resembles certain parts of the fauna of the Madison limestone of the west.

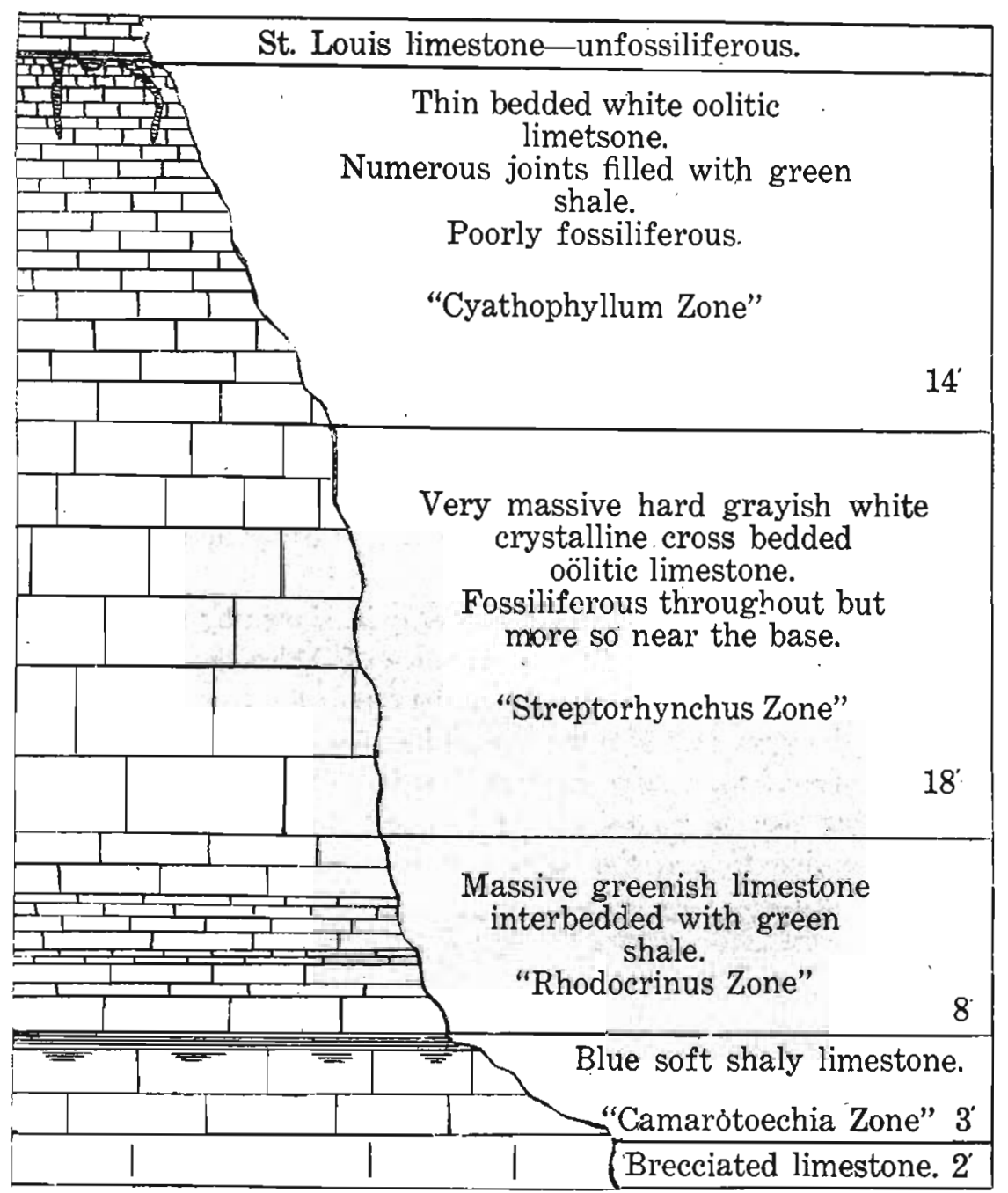

Fic. 59.-Type section of the Gilmore City beds. These beds are exposed in Pocahontas and Humboldt counties and are correlated with the Alden limestone.

The unconformable contact of the Iowa Falls member with the Alden may be seen at several places along Iowa river west of Iowa Falls. The first exposure in which this contact may be seen is located 
on the right hand bank of Iowa river about 200 feet upstream from the railroad bridge at 39 of section 21, Range 21 West, Township 89 North. Several other exposures of this contact may be seen along the

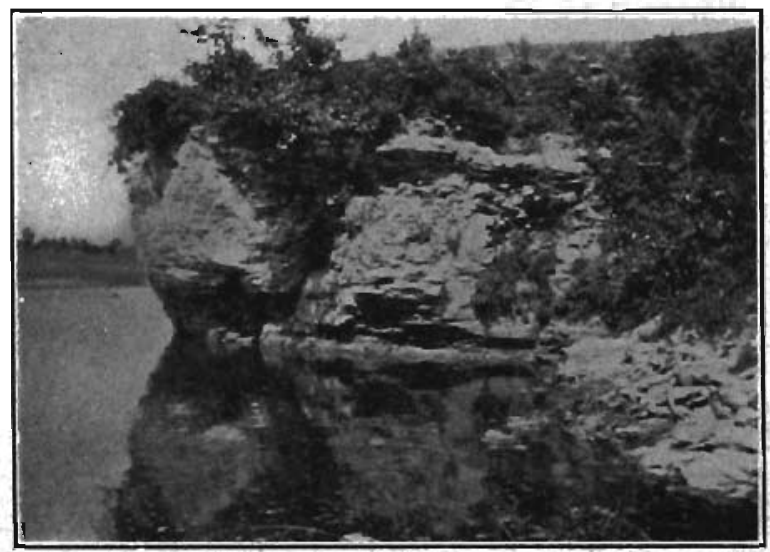

Frc. 60.-Alden limestone west of Iowa Falls on Iowa river.

river bank in the northern part of section 21. Farther up the river the Iowa Falls is cut out entirely.

The magnitude of this unconformity may be shown by the fact that three miles down Iowa river from the town of Alden the Alden limestone is seen resting unconformably on the top of the Iowa Falls member and at the town of Alden the Iowa Limestone Company has drilled from the base of the quarry through 120 feet of Alden limestone before striking foreign material. At 120 feet the drill penetrated the lithographic limestone of the Eagle City member. The entire 75 feet

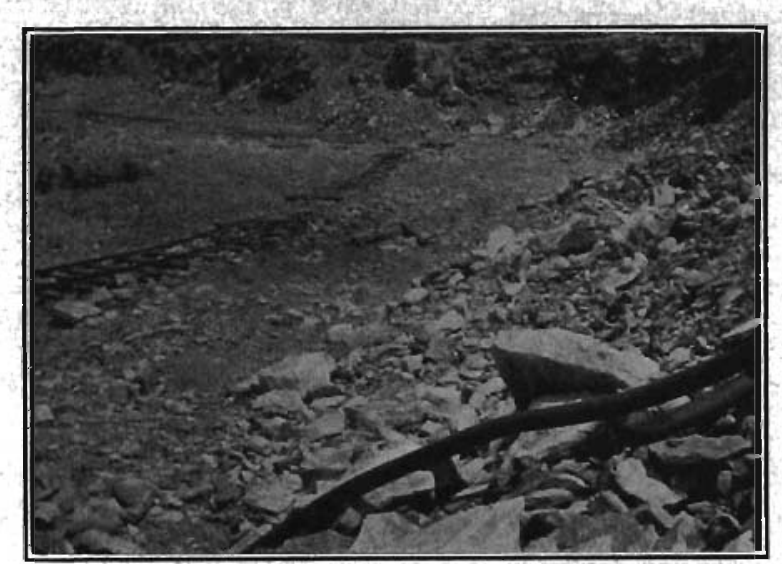

Frg. 61--Alden limestone in the quarry of the Iowa Limestone Company at Alden. 
of the Iowa Falls member has been cut out within a distance of three miles.

The Iowa Falls member is not exposed outside of the immediate vicinity of Iowa Falls. Certain thick sections of dolomite in well sections to the west of Iowa Falls are suggestive of the member, but this cannot be definitely determiried.

Correlation.-The fauna of the Iowa Falls member is not large enough to allow for many generalizations. A considerable number of the species present were undoubtedly derived from the earlier Hampton fauna. Spirifer platynotus, Spirifer louisianensis, Spirifer biplicoides, Spirifer missouriensis, Streptorhynchus tenuicostatum, Productus sedaliensis, Rhipidomella tenuicostata, Straparollus obtusus and Orthoceras indianense are all common fossils of the Hampton formation.

There are 20 species' in the Iowa Falls member and of these 18 are found elsewhere in the Hampton of Iowa, 12 are found in the Chouteau at Newark, Missouri, and eight in the Chouteau of central Missouri.

Because the strongest faunal relations of the Iowa Falls member seem to be with the underlying Hampton members, and because stratigraphically the Osage beds may be demonstrated to overlap unconformably on to the Hampton surface and to pinch out long before north-central lowa is reached, and because the lithology of the Iowa Falls does not resemble that of the Osage in any way, the Iowa Falls member is considered to be part of the Hampton formation.

The Iowa Falls member marks the upper limit of the Kinderhook series in Iowa, which at its maximum thickness will total 625 feet. The Maple Mill and English River formations in the southeastern province are 375 feet thick at their maximum development at Burlington, and the Hampton formation is 250 feet thick in the north-central province.

\section{The Hampton Formation at LeGrand}

A series of exposures of the Hampton formation may be seen along [owa river in eastern Marshall county and in western Tama county. A few minor exposures of the formation may be seen in the southern part of Grundy county near Conrad and Beaman, on Wolf creek. Other minor exposures may be seen in the northern central part of Marshall county in the vicinity of Albion and again in the vicinity of 
Liscomb. These exposures will be grouped together and described as the LeGrand section.

This group of exposures is located near the town of LeGrand, which is about nine miles east of Marshalltown and is in the heart of the best exposures of the Hampton formation in this region. Several large quarries are now in operation in the vicinity of LeGrand and there are a score of abandoned quarries near the town.

This group of exposures has long been famous for its crinoidal remains. It was in some of these old quarries that Meek and Worthen, Miller and Gurley, R. R. Rowley, Samuel Calvin, and Wachsmuth and Springer first collected the crinoids that have become famous the world over. The LeGrand crinoids have been particularly desirable because of their excellent preservation. These crinoids grew in patches much as a flower garden grows today. Once the main large nest at LeGrand was exhausted it became difficult to find a single good specimen. If one visits the LeGrand quarries it is seldom that more than a badly broken specimen is found. The horizon in which the large nest occurred appears at present to be almost entirely barren. The layers in which the crinoids were found consist of brown soft banded limestone in which it is difficult to find even so much as a crinoid stem. Other nests of these crinoids undoubtedly populated the sea bottom at this time and it seems very likely that others may be uncovered by quarrying operations in the future. The crinoids that grew in this large nest were buried by fine sediments in a condition almost as good as that of the living state. A great number of complete crinoids have been found, complete from the most delicate pinnules on the arms to the cirri on the ends of their stems. A part of the original color of these crinoids is still preserved in the fossil specimens. The original large nest consisted of a lenticular mass of soft slightly magnesian limestone not over one foot in thickness. The edges of this mass pinched down to a few inches in thickness. The crinoids occurred along definite planes within this limestone and often the slabs had to be split to expose the surfaces on.which the crinoids lay. The areal extent of this nest was not over fifty by sixty feet. The horizon of the nest was located definitely at 34 feet above the contact of the oolitic limestone with the brown to gray magnesian limestones. This contact may be seen in the quarry from which the crinoids were taken. The horizon from which the crinoids came may now be seen to be a brown soft even-grained 
banded earthy-appearing slightly magnesian limestone. It may be more definitely located by a close study of the section. In the zone directly below the crinoid horizon there may be seen several layers of brown or blue hard crystalline crinoidal limestone that appear almost identical with many beds that are found in the Burlington limestone. These crinoidal limestone beds are interbedded with softer brown banded limestone beds and occasionally a little chert. The beds from which the crinoids were taken are about three feet above the last of these crinoidal limestone beds.

The quarry from which the crinoids were taken has been reopened and is now (1929) in operation. The face of the quarry has been shifted some 75 feet to the east of the position at which it stood when the crinoids were being removed, and the present quarry floor is located considerably above the position of the old quarry floor. The old quarry penetrated down through the oolitic limestone that forms the base of the formation in this region and the new one has its floor at the top of this oölitic layer or some 18 feet higher. The old quarry hole which penetrated through the oölitic limestone may still be seen at the south end of the present quarry although it is now partly filled with water. This old quarry hole in the oolitic limestone is about 100 feet in length and forms a marker for the nest of crinoids. The heart of the crinoid bed was located about 50 feet up from the northern end and directly to the east of this old quarry hole.

The crinoids of the LeGrand region are not entirely confined to the zone in which the large nest was found. The species that make up the crinoidal limestones in the zone below are for the most part the same species that occur in the large nest. Broken flattened calyces of crinoids that are identical with those found in the upper nests may be collected from these highly crystalline limestone ledges. A few very good specimens showing the arms and stems and calyces have been found on the bedding planes of this lower zone.

The soft gray earthy limestone beds that lie just above the oolitic limestone locally carry small nests that in part resemble the upper nest. The crinoidal association in this lower zone is markedly different from that of the upper one. This lower zone is particularly noted for its abundance of remains of small inadunate crinoids. The crinoids of this lower zone, however, are not confined entirely to these nests, and a few specimens may be expected anywhere within the blocks or 
on the bedding planes of this limestone. Rows of stems may often be seen protruding from great blocks of this material.

The uppermost beds at LeGrand contain an important amount of fragmented crinoidal material which occurs only as broken or flattened specimens. One species of Cactocrimus and several species of Platycrimus occur in these upper beds.

The crinoids have been confined for the greater part to the large south quarry. However, a few have been taken from the large north quarry, several from the county quarry on Timber creek, a few from the new quarry on the "Devils Anvil", and several from the abandoned quarries to the west of the large south quarry.

The natural exposures of the material are usually weathered to such an extent that very few fossils may be collected. These limestone beds contain a great amount of dolomitic material which upon weathering appears much like the Wassonville or Maynes Creek members of the Hampton formation.

Distribution and Thickness. - The exposures described under the LeGrand section are confined to Marshall county, the western edge of Tama county, and the southern edge of Grundy county. The main exposures under consideration are within a few miles of the city of LeGrand and most of them are located in the valley of Iowa river.

The thickness of the LeGrand section is about 80 feet and the greater part of this may be seen in continuous sections. The lower oölitic member is usually incompletely exposed in the recently opened quarries. Usually only parts of the upper thin-bedded zone are seen. It is not possible to establish a definite upper limit to the LeGrand beds, although the upper part would be correlated with the lower part of the Eagle City member to the north. The maximum section exposed immediately in the vicinity of LeGrand is about 80 feet.

Lithologic Character. - The Lefrand beds have been divided into life zones and named for the most abundant fossils which they contain.

The Schellwienella planumbona zone.-This zone is named for Schellivienella planumbona, which is found abundantly at this horizon. Lithologically it consists of hard gray rather thin-bedded oölitic limestone, which may be easily recognized from other oölitic beds of the LeGrand section by the larger size of its oölites. 


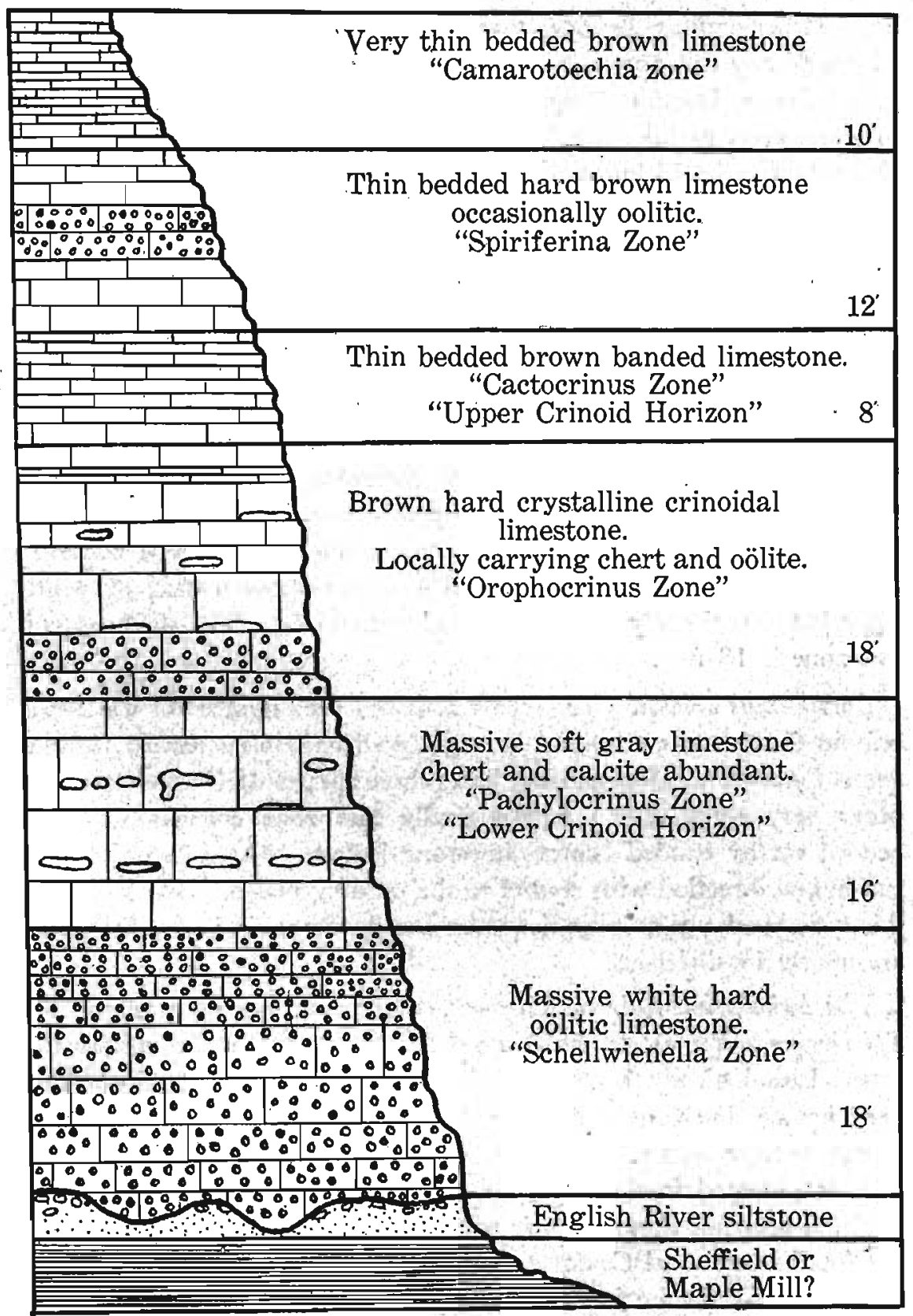

FrG. 62.-Composite section of the LeGrand beds showing life zones. 
The Pachylocrinus genista zone.-This zone is named for the crinoid Pachylocrinus genista, that is found throughout the horizon. Lithologically this zone consists of very soft earthy gray to yellowish very massive limestone ledges, which contain a large number of gray to white chert nodules filled with Chonetes multicostata. The zone is about 18 feet in thickness.

The Orophocrinus conicus zone.-This zone is named for the small blastoid Orophocrinus conicus, which may be found at almost any horizon within the zone. Lithologically the zone shows considerable range. The main characteristics by which it may be distinguished are the hard crystalline crinoidal ledges which it contains. These crinoidal ledges are of either a brown or a bluish color and might very easily be confused with ledges of the Burlington limestone. They are interbedded with yellow to brown, either massive or very thin-bedded limestone beds. Locally the basal part of the zone contains a semi-oölitic limestone layer about two feet six inches thick. The zone contains large amounts of nodular chert which is usually of a gray or white color but occasionally may be banded with black. The thickness of this zone is 18 feet.

Cactocrinus arnoldi zone.-This zone has been named for the fossil crinoid Cactocrinus arnoldi. It might well have been named for the genus Cactocrinus alone since it bears three species of Cactocrinus that occur very abundantly. Lithologically this zone consists of thinbedded earthy banded brown limestone ledges. These brown bands run in any direction with respect to the bedding planes. The layers of this zone break out as large flat slabs usually about six inches thick and are poorly fossiliferous.

The Spiriferina solidirostris zone.-This zone has been named for Spiriferina solidirostris, which occurs very commonly throughout the zone. Lithologically the zone consists of very fossiliferous thin-bedded hard brown limestone beds. At several places small beds of oölitic limestone have been seen. Many of the weathered surfaces are matted with fragmented fossils. The zone is about 12 feet in thickness.

Camarotoechia chouteauensis zone.-This zone has been named for the fossil brachiopod Camarotoechia chouteauensis, which occurs very abundantly in the horizon. This zone consists of about 10 feet of very thin-bedded brown limestone beds. The average thickness of the individual beds is less than two inches. 
Paleontology.-The Schellwienella plammbona zone is exposed at many places along the bluffs of Iowa river between LeGrand in Marshall county and Butlerville in Tama county. The best exposure is located at the old mill on the right bank of Iowa river just downstream from the highway bridge that crosses at this point. This exposure is located at 47 of section 1, LeGrand township. The entire section of the zone is exposed here, with both its upper and lower contacts.

Very fossiliferous exposures may be seen on the eastern end of the "Devils Anvil", at 76 of section 7, Indian Village township, Tama county. A small creek cuts through the oölitic member at this point, making each of the beds of the zone easily accessible.

Fanna of the Schellwienella Zone

(Species marked * were listed by Van Tuyl)

Zaphrentis sp.*

Schellwienella inflata Weller

Schellwienella planumbona Weller

Schellwienella sp.**

Chonetes logani $\mathbf{N}$. and P.*

Chonetes burlingtonensis Weller

Chonetes illinoisensis Worthen

Productus ovatus Hall

Productus sp.

Productella sp.*

Productella sp.*

Rhipidomella tenuicostata Weller

Dielasma sp.*

Camarotoechia tuta Miller

Spirifer platynotus Weller

Spirifer sp.*

Syringothyris sp.*

Brachythyris peculiaris (Shumard)

Cliothyridina tenuilineata (Rowley)* ${ }^{*}$.

Athyris crassicardinalis White

Composita opposita (W. and W.)

Schizodus sedaliensis M. and G.

Pterinopecten nodocostatus W. and W.

A viculopecten sp.

Straparollus obtusus (Hall)

Orthoceras sp.*

The Pachylocrinus zone is best exposed in the main large south quarry, which is located about a mile and a half north of LeGrand on the right bank of Iowa river at 77 of section 1, LeGrand township. The floor of this quarry is located on the top of the oölitic limestone. The Pachylocrinus zone occupies the base of the quarry face. In the extreme southern end of this quarry the old abandoned quarry floor is 
in the Pachylocrinus zone. A large number of the fossils were collected from these old flat weathered surfaces.

The zone is also very well exposed in the county quarry on Timber creek at 97 of section 8, LeGrand township. Here the Pachylocrinus zone forms the base of the quarry face as in the south LeGrand quarry. Numerous other exposures might be mentioned, but these two are particularly favorable for a study of the fossils.

Fanna of the Pachylocrinus genista Zone

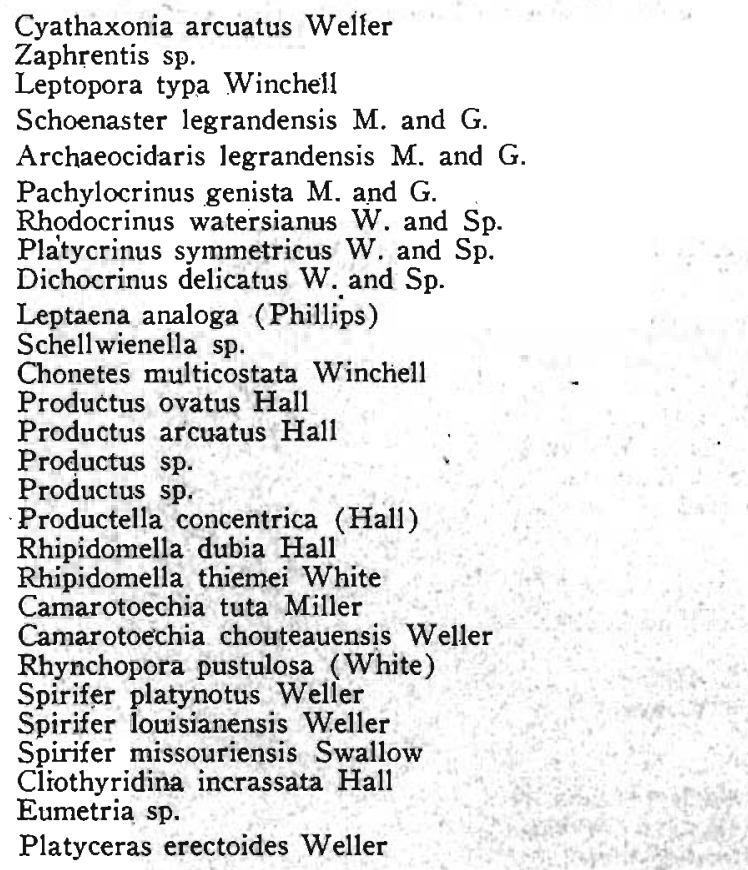

This zone will correspond very closely with the Wassonville cherts - and the base of the Maynes Creek member. At all three places it is characterized by nodules of chert filled with Chonetes multicostata. The small form of Leptaena analoga which occurs abundantly in the Wassonville is also "found in this zone. It is also especially crowded with the remains of small inadunate crinoids, several of which belong to the genus Pachylocrinus. This is the lowest horizon in which the crinoids are found in nests.

The Orophocrinus zone is very well exposed in several places near LeGrand, the best of which is probably in the south quarry. This zone forms the central part of the face for the entire length of the quarry. 
The zone is also well exposed in the north quarry on the opposite side of Iowa river. Very fossiliferous ledges belonging to this zone may also be seen in the county quarry on Timber creek. An exceptionally fossiliferous part of this zone is exposed in the floor of an old abandoned quarry about 500 feet to the west of the south end of the large south quarry at LeGrand.

The fauna of the zone comes mainly from the crinoidal ledges. The major part of it comes from the bedding planes at the top of these ledges and a smaller part from within these ledges. About three feet of very fossiliferous semi-oölitic limestone occurs in this zone in the county quarry on Timber creek.

Fanina of the Orophocrinus conicus Zone

Zaphrentis cliffordana $\mathrm{E}$. and $\mathrm{H}$.

Zaphrentis wortheni Weller

Cyathaxonia arcuatus Weller

Leptopora typa Winchell

Orophocrinus conicus W. and $\mathrm{Sp}$.

Orophocrinus fusiformis W. and Sp.

Orophocrinus stelliformis (O. and Shu.)

Eutaxocrinus fletcheri (Worthen)

Rhodocrinus watersianus W. and Sp.

Megistocrinus nobilis W. and Sp.

Aorocrinus immaturus $W$, and Sp.

Cactocrinus arnoldi W. and Sp.

Platycrinus sp.

Platycrinus sp.

Dichocrinus sp.

Agelacrinus legrandensis $\mathrm{M}$. and $\mathrm{G}$.

Leptaena analoga Phillips

Schellwienella inflata Weller

Schellwienella planumbona Weller

Schellwienella inaequalis Weller

Streptorhynchus sp.

Productus arcuatus Hall

Productella concentrica (Hall)

Rhipidomella burlingtonensis Hall

Schizophoria sedaliensis Weller

Cranaena sp.

Dielasma chouteautensis Weller

Dielasma sp.

Camarotoechia chouteauensis Weller

Spiriferina solidirostris (White)

Spiriferina sp.

Spirifer biplicoides Weller

Spirifer platynotus Weller

Spirifer gregeri Weller

Spirifer legrandensis Rowley

Spirifer calvini Weller

Spirifer louisianensis Weller

Spirifer sp.

Brachythyris chouteauensis Weller

Cliothyridina sp.

Athyris crassicardinalis White 
Bellerophon blairi $M$. and $G$.

Igoceras subplicatum $M$. and $W$.

Capulus piso Walcott

Capulus paralius $W$. and $W$.

Strophostylus bivolve W. and W.

Proetus sp.

Griffithides sp.

Fish tooth, 1.

Fish tooth, 2.

Fish tooth, 3.

Fish tooth, 4.

The Cactocrinus zone is well exposed in both the north and south quarries at LeGrand. It may be easily identified in nearly all of the abandoned quarries in the region. Lithologically it consists of rather thin-bedded soft earthy banded limestone ledges in which the bands run with no apparent relation to the bedding planes.

The zone is characteristically poorly fossiliferous, with ledges appearing almost barren. The fossils that are found in this zone are very well preserved, suggesting a period of rapid sedimentation in relatively quiet waters. The large LeGrand crinoid fauna was taken from the lower ledges of this zone.

Fauna of the Cactocrinus armoldi Zone.

Orophocrinus conicus W. and Sp.

Orophocrinus fusiformis $W$. and Sp.

Archaeocidaris legrandensis $M$. and $G$.

Rhodocrinus kirbyi W. and Sp.

Rhodocrinus nanus $\mathrm{M}$. and $\mathrm{G}$.

Rhodocrinus watersianus $W$. and $S p$.

Megistocrinus nobilis $W$. and $\mathrm{Sp}$.

Batocrinus macbridei W. and Sp.

Batocrinus poculum $M$. and $G$.

Aorocrinus parvibasis $W$. and $\mathrm{Sp}$.

Aorocrinus immaturus $\mathrm{W}$. and $\mathrm{Sp}$.

Aorocrinus radiatus $W$. and $S p$.

Cactocrinus ornatissimus $W$. and $\mathrm{Sp}$.

Cactocrinus nodobrachiatus $W$. and $S p$.

Cactocrinus arnoldi W. and Sp.

Platycrinus symmetricus $W$. and $S p$.

Platycrinus agassizi $W$. and $\mathrm{Sp}$.

Dichocrinus inornatus $W$. and $S p$.

Dichocrinus delicatus $W$. and $\mathrm{Sp}$.

Dichocrinus cinctus $M$. and $G$.

Eutaxocrinus fletcheri (Worthen)

Taxocrinus intermedius $W$. and $S p$.

Pachylocrinus scopae (M. and G.)

Pachylocrinus genista ( $M$. and G.)

Pachylocrinus elegantulus (W. and Sp.)

Pachylocrinus globosus (W. and Sp.)

Pachylocrinus legrandensis (M. and G.)

Pachylocrinus spartarius (M. and G.)

Goniocrinus sculptilis $M$. and $G$.

Decadocrinus maccabei (M. and G.) 


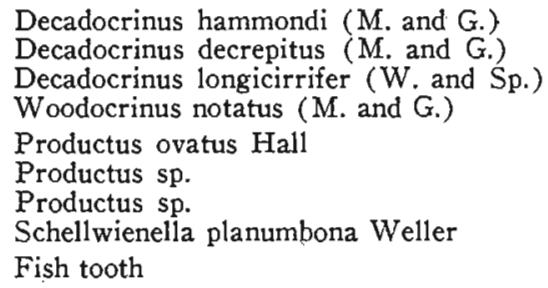

The Spiriferina zone forms the upper part of the quarry faces in both of the large LeGrand quarries. It is also well exposed at the "Devils Anvil" in Tama county. The zone consists of hard brown thin beds of highly fossiliferous limestone. These beds are much more fossiliferous than any other part of the LeGrand section, but the fossils are much fragmented. Some of the slabs from this zone are made up entirely of masses of Spiriferina solidirostris. Spirifer platynotus. Rhipidomella dubia, and an undescribed form of Cactocrinus occur very abundantly in the zone.

Faund of the Spiriferina solidirostris Zone

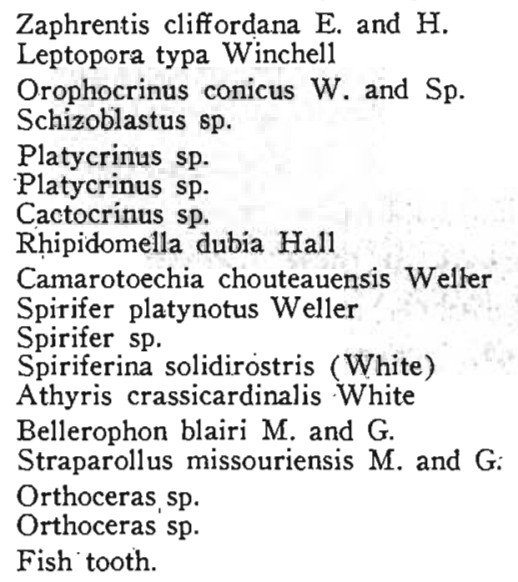

The Camarotoechia zone is not exposed in either of the two main quarries at LeGrand. It may be seen only on the small tributaries of Iowa river farther back from the main stream where erosion has not removed the beds. The zone is best exposed at Rockton at 88 of section 21, Range 17 West, Township 84 North, and it is also well exposed in the bluffs of the small tributary that enters Iowa river in the southcentral part of section 36, two miles north of LeGrand. The zone is also exposed on Wolf creek, in the vicinity of Conrad and Beaman, in the southern part of Grundy county. 
The ledges of this zone are not exceptionally fossiliferous but certain beds are filled with Camarotoechia chouteauensis and several species of Schellwienella.

Fauna of the Camarotoechia chouteauensis Zone

Orophocrinus conicus $\mathrm{W}$. and $\mathrm{Sp}$.

Schellwienella crenulicostata Weller

Schellwienella planumbona Weller

Schellwienella sp.

Schellwienella sp.

Productella concentrica (Hall)

Schizophoria sp.

Rhipidomella sp.

Cranaena sp.

Rhynchotreta sp.

Camarotoechia chouteauensis Weller

Spiriferina solidirostris (White)

Spirifer legrandensis Weller

Straparollus obtusus (Hall)

Conularia sp.

Stratigraphy.-The L.eGrand beds overlie the English River formation unconformably. Only one of the exposures beneath the LeGrand beds carries a fauna and this fauna belongs definitely to the English River formation. It is highly probable that over the greater part of this area the LeGrand beds lie unconformably on the Sheffield formation. The exposure at the old mill one mile north of LeGrand has more the appearance of Sheffield material than of English River. It is not possible to determine definitely to which of these formations it should be referred because of the lack of fossils.

The LeGrand beds probably grade conformably into beds that would be correlated with the basal part of the Eagle City member. The actual contacts are not exposed but probably exist farther to the north where the Eagle City material has not been removed by erosion.

Correlation.-The Schellwienella zone of the LeGrand beds is correlated with the upper part of the Chapin member of the north-central province and with the upper part of the North Hill member of the southeastern province. The fauna is almost identical with that of the Schellwienella zone of the North Hill member.

The Pachylocrinus and Orophocrinus zones are correlated with the Wassonville member of the southeastern province. The chert bands present in the LeGrand at this horizon have the typical. Wassonville fauna present.

The Pachylocrinus, Orophocrinus, Cactocrinus and Spiriferina 
zones are correlated with the Maynes Creek member of the northcentral province. It is difficult to draw the exact line between the portion of the LeGrand beds that should be referred to the Eagle City and the portion that should be referred to the Maynes Creek. The lower two zones of the LeGrand undoubtedly correspond to the lower cherty part of the Maynes Creek.

The Camarotoechia zone is correlated with the lower oolitic limestone of the Eagle City member. Lithologically and faunally these zones are much alike.

Type Sections in North-central Iowa

Section Exposed in Old Quarry Onc Mile West of Chapin

FEET INCHES

6. Dolomite, thin-bedded, soft, yellowish, very fossiliferous, filled with irregular masses of gray and black chert ............ 3 6

5. Dolomite, massive, moderately hard, dark brown, filled with casts

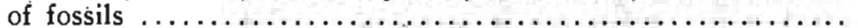

4. Dolomite sand, soft, granular, yellow, very fossiliferous .........

3. Limestone, gray to brown, slightly crinoidal, oölitic in part, massive, filled with fossils. Schizoblastus roemeri, Cyathaxonia arcu-

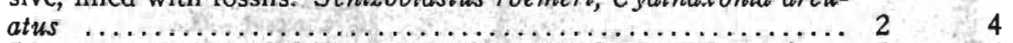

2. Limestone, gray, oölitic, hard, massive, slightly fossiliferous : $\ldots 2 \quad 2 \quad 6$

1. Dolomite, massive, dark chocolate brown, hard, slightly crinoidal, banded, fossiliferous $\ldots \ldots \ldots \ldots \ldots \ldots \ldots \ldots \ldots \ldots \ldots \ldots . \ldots \ldots$

Beds 1,2 and 3 are referred to the Chapin member and beds 4, 5 and 6 to the Maynes Creek member. Beds 5 and 6 carry the main part of the fauna that has been listed from the Productus sedaliensis zone.

Section showing the lower beds of the Chapin member exposed on the south tank of Maynes Creek at 67 of section 22, Reeve township, Franklin county.

7. Limestone, very thin-bedded, brown to gray, dolomitic at top, carrying much chert, slightly fossiliferous ................

6. Shale, brown, earthy, irregular contact above and below. Products of disintegrated limestone $\ldots \ldots \ldots \ldots \ldots \ldots \ldots \ldots \ldots \ldots$

5. Dolomite, thin-bedded, brown, fairly hard, a little brown chert,

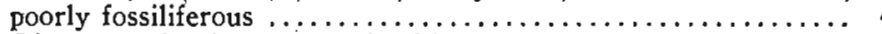

4. Limestone, hard, brown, dolomitic, poorly bedded, fractured, un-

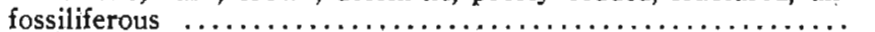

3. Limestone, very hard, chunky, white, semi-oölitic, itregular bed-

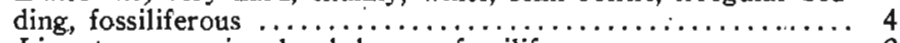

2. Limestone, massive, hard, brown, fossiliferous ............ 2

1. Limestone, thin-bedded, hard, brown, slabby, crinoidal, very fos-

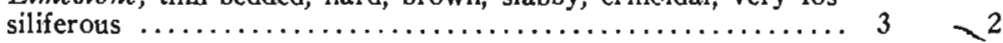

The entire section is referred to the Streptorhynchus tenuicostatum zone of the Chapin member.

The following exposure of the Chonetes multicostata zone of the Maynes Creek member may'be seen in an old quarry on the east bank of Spring creek just north of the city of Hampton in Franklin county. 


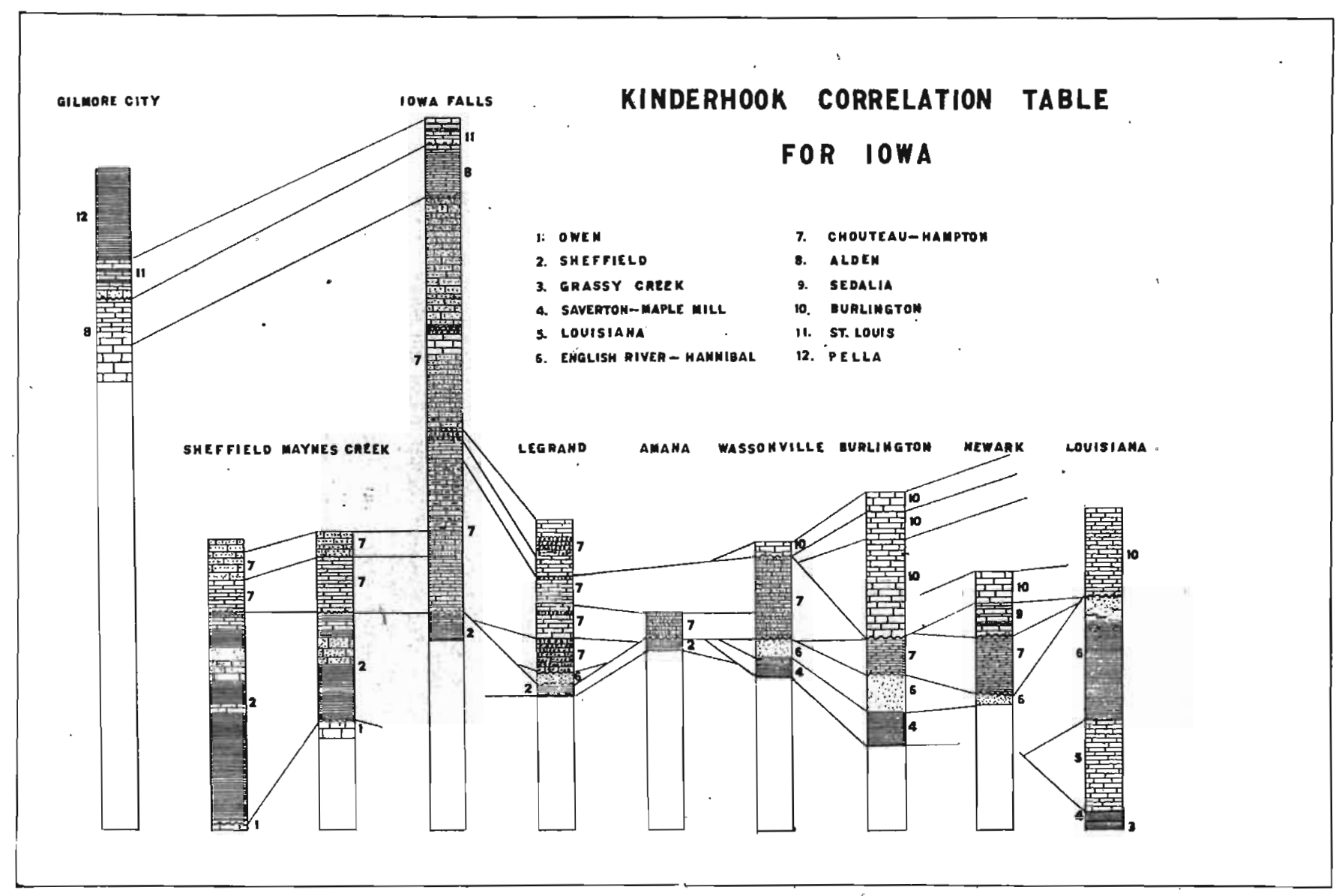

Frc. 63.-Kinderhook correlation ehart showing the thick section of the Hampton formation at Iowa Falls and emphasizing the unconformity at the hase of the Hampton formation. Scale: 1 inch equals 100 feet. 
7. Dolomite, thin-bedded, soft, brown, interbedded with much

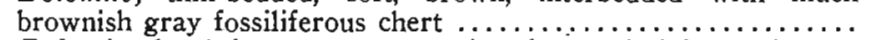

6. Dolomite, hard, brown, more massive than underlying and over-

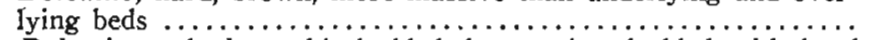

5. Dolomite and chert, thin-bedded, brown, interbedded with hard brown to gray fossiliferous chert .................. 4

4. Chert, hard, fractured, slightly banded, brown to white, fossilif-

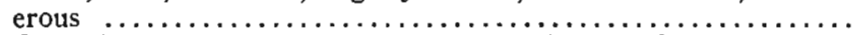

3. Dolomite, massive, yellow to brown, poorly fossiliferous ....... 3

2. Chert, yellowish to white, soft, filled with fossils. Chonetes multicostata, Spirifer platynotus and Camarotoechia chouteauensis...

1. Dolomite, massive, brown to yellow, interbedded with fossiliferous white chert in bands and in nodules ................ 8

Fet Inches 43 23 4

This section of the Rhipidomella zone of the Eagle City member is exposed in an old quarry. three miles north of Ackley at 444 of section. 13; Osceola township.

3. Limestone, thin-bedded, hard, slightly oölitic, crinoidal in part, fossilif-

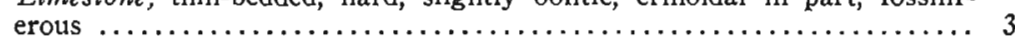

2. Limestone, massive, brown, hard, banded, crinoidal. Filled with Rhipidomella burlingtonensis ................................ $1 \%$

1. Limestone, thin-bedded, slightly oölitic, gray to brown, partly crinoidal ... 4

The following Eagle City exposure is located just south of the highway bridge at Eagle City in an abandoned quarry. This is the type section of Van Tuyl.

8. Dolomite, thin-bedded, slabby, yellow to brown, contains a few chert nodules and one or two beds of hard dark brown dolomite $\ldots \ldots \ldots \ldots \ldots \ldots 8$

7. Dolomite, massive, very soft, yellow, unfossiliferous $\ldots \ldots \ldots \ldots \ldots \ldots \ldots . . . . .6$

6. Dolomite, thin-bedded, soft, sandy, carrying a little chert. Upper part appears to be a replaced oölitic limestone ........................ 10

5. Dolomite, brownish, porous, possibly once oölitic, very fossiliferous ..... 3

4. Dolomite, chocolate brown, bedding planes about 8 inches apart, unfossilif-

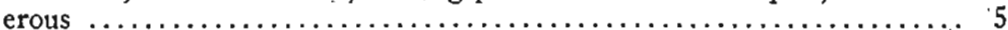

3. Limestone, thin-bedded, gray, oölitic, fractured, very fossiliferous ...... $11 / 2$

2. Dolomite, massive in upper part, thin-bedded below, dark brown, unfossil-

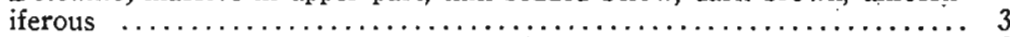

1. Limestone, thin-bedded, gray to white, slightly oölitic, very fossiliferous .. 3

The lower five beds are referred to the Spirifer biplicoides zone and the upper three to the Straparollus zone.

The following section of the upper part of the Eagle City member and the lower part of the Iowa Falls member is exposed in the Ellsworth stone quarry on the left bank of Iowa river in Iowa Falls.

FEET
Folomite, thin-bedded, soft, sandy, coarse-grained,

9. Dolomite, thin-bedded, soft, sandy, coarse-grained, unfossiliferous ...... 5

8. Dolomite, brown, soft, sandy, thin-bedded, filled with casts of Straparollus obtusus and a simple coral. A Loxonema, a Conocardium and a Spirifer are also quite abundant $\ldots \ldots \ldots \ldots \ldots \ldots \ldots \ldots \ldots \ldots \ldots \ldots \ldots . . \ldots$

7. Dolomite, fairly massive, chocolate brown, soft, containing calcite nodules, interbedded with green, red and brown shaly material .............. 11 
6. Dolomite, hard, porous, dark brown, contains calcite nodules, many casts of fossils, Spirifer platynotus, Rhipidomella burlingtonensis and a Reticu-

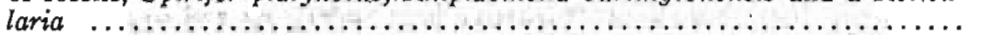

5. Shale, soft, yellowish, gray, blue, containing considerable limonite and calcite, rests on rather uneven surface of oölitic limestone $\ldots \ldots \ldots \ldots \ldots$.

4. Limestone, hard; thin-bedded, white to gray, oölitic, much fractured, stylolites, veins of calcite, filled with Camarotoechia subglobosa ...........

3. Limestone, dense, hard, white to gray, lithographic, ripple-marked, thinbedded, poorly fossiliferous. Contains two dolomite beds. Stromatopo-

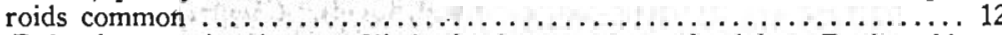

2. Dolomite, massive, brown, filled with large masses of calcite. Pyrite, siderite and dolomite crystals locally $\ldots \ldots \ldots \ldots \ldots \ldots \ldots \ldots \ldots \ldots \ldots, 61 / 2$

1. Dolomite, very massive, dark brown, banded, very hard, unfossiliferous ..

Beds 1 and 2 are referred to the Straparollus zone of the Eagle City member. Beds 3 and 4 are referred to the Camarotoechia subglobosa zone of the Eagle City. Beds 5 and 6 are referred to the Spirifer platynotus zone of the Iowa Falls member. Beds 7,8 and 9 are referred to the Loxonema zone of the Iowa Falls member.

The following section shows the upper part of the Iowa Falls member and the lower part of the Alden limestone and is exposed in the old Ivanhoe quarry at 73 of section 16 , Range 21 West, Township 89 North.

4. Limestone, thin-bedded, soft, cream-colored to bluish, bedded with green shale, slightly crinoidal, containing very much fragmented fossils. Some portions slightly oulitic . ............................... 14

3. Limestone, massive, soft, cream-colored, filled with crinoidal fragments .. 2

2. Limestone, hard, massive, brown to blue, partly crinoiclal. Fish tooth. Rests on very uneven weathered surface of Iowa Falls dolomite ........ 4

1. Dolomite, thin-bedded, brown, highly weathered, surface irregular, covered with solution pits. Nodular-like masses of hard dolomite left on surface - 4

Bed 1 is referred to the Iowa Falls member. Beds 2, 3 and 4 are referred to the Alden limestone.

\section{Bibliography}

Arey, M. F., Geol. of Butler County: Iowa Geol. Survey, Vol. XX, pp. 1-59, 1910. ..........., Geol. of Grundy County: Iowa Geol. Survey, Vol. XX, pp. 61-95, 1910. Bain, H. F., Geol. of Washington County: Iowa Geol. Survey, Vol. V, pp. 115$173,1896$.

Bassler, R. S., The Waverlyan Period in Tennessee: U. S. Nat. Mus. Proc, Vol. 41, No. 1851, pp: 209-224, 1911.

Beyer, S. W., Geol. of Hardin County: Iowa Geol. Survey, Vol. X, pp. 243-305, 1900. ..........., Geol. of Marshall County: Iowa Geol. Survey, Vol. VII, pp. 197-262, 1897.

........., Geol. of Story County: Iowa Geol. Survey, Vol: IX, pp. 155-245, 1899.

Bridge, Josiah, Residual Mississippian Faunas of Phelps County, Missouri: Jour. Geol., Vol. 25, 1917. 
Butts, Charles, The Mississippian Series of Eastern Kentucky: Kentucky Geol. Surv., Series VI, Vol. 7, p. 188, 1922.

Calvin, Samuel, Geol. of Cerro Gordo County: Iowa Geol. Survey, Vol. VII, pp. 117-195, 1897.

........., Geol. of Johnson County: Iowa Geol. Survey, Vol. VII, pp. 33-116, 1897.

.........., Some Geologic Problems in Muscatine County, Iowa: Am. Geol., Vol. 3, p. 25, 1899.

Cooper, C. L., The Sylamore Limestone: Oklahoma Geol. Survey, Cir. 9, 1926.

Darton, N. H., Comparison of the Stratigraphy of the Black Hills, Bighorn Mountains, and the Rocky Mountain Front Range: Geol. Soc. Am. Bull. 15, p. 306, 1904.

Girty, G. H., Geology of Yellowstone National Park: Mon. 32, U. S. G. S., Pt. 2, pp. 479-496, 1899.

Hall, James, On the Carboniferous Limestones of the Mississippi Valley: Am. Jour. Sci., Ser. 2, Vol. 23, p. 187, 1857.

..........., Geol. of Iowa, Vol. 1, Pts. 1 and 2, 1858.

Keyes, Charles R., The Principal Mississippian Section: Geol. Soc. Am., Vol. 3, p. 283, 1892.

.........., Paleontology of Missouri: Missouri Geol. Survey, Vol. 4, p. 271, 1894.

..........., Marked Unconformity Between the Carboniferous and Devonian Strata in the Upper Mississippi Valley: Am. Jour. Sci, Ser. 4, Vol. 36, p. 160, 1913. ..., Geol. of Des Moines County: Iowa Geol. Survey, Vol. III, pp. 409-492, 1894.

Kindle, E. M., The Devonian and Lower Carboniferous Faunas of Southern Indiana and Central Kentucky: Am. Pal., Bull. 12, p. 111, 1899.

Krey, Frank, Structural Reconnaissance of the Mississippi Valley Area from Old Monroe, Missouri, to Nauvoo, Illinois: Illinois State Geol. Surv., Bull. 45, 1924.

Macbride, T. H., Geol. of Hamilton and Wright Counties: Iowa Geol. Survey, Vol. XX, pp. 97-138, 1910.

.........., Geol. of Humboldt County: Iowa Geol. Survey, Vol. IX, pp. 109-154, 1899.

.........., Geol. of Pocahontas, Palo Alto and Emmet Counties: Iowa Geol. Survey, Vol. XV, pp. 227-276, 1905.

Meek, F. B., and Worthen, A. H., Description, of Invertebrates from the Carboniferous System: Illinois Geol. Survey; Vol. 5, p. 323, 1873.

........... Fossils of the Kinderhook Group: Illinois Geol. Survey, Vol. 3, p. 450, 1868.

.........., Invertebrate Fossils from the Kinderhook Group: Illinois Geol. Survey, Vol. 2, p. $145,1866$.

Miller, S. A., and Gurley, Wm. F. E., New Species of Paleozoic Invertebrates from Illinois and Other States: Illinois State Mus. Nat. Hist., Bull. 11, 1896. ...., New Genera and Species of Echinodermata: Illinois State Mus. Nat. Hist., Bull. 5, 1894.

Miller, S. A., Subcarboniferous Fossils from the Lake Valley Mining District of New Mexico with Descriptions of New Species: Jour. Cinn. Soc. Nat. Hist., Vol. 4, pp. 306-315, 1881. 
Moore, R. C., Early Mississippian Formations of Missouri : Missouri Bur. of Geol. and Mines, Vol. 21, 2d Ser., 1928.

Norton, W. H., Underground Water Resources of Iowa: Iowa Geol. Survey, Vol. XXI, 1911.

.........., Deep Wells of Iowa: Iowa Geol. Survey, Vol. XXXIII, 1927.

Roth, Robert, A Comparative Faunal Chart of the Mississippian and Morrow Formations of Oklahoma and Kansas: Oklahoma Geol. Surv.," Cir. 18, 1929.

Rowley, R. R., Geology of Pike County: Missouri Bur. Geol. and Mines, Ser. 2, Vol. 8, p. 121, 1908.

Sardeson, F. W., The Carboniferous Formations of Humboldt, Iowa: Am. Geol., Vol. 30, p. 300, 1902.

Savage, T. E., Geol. of Tama County: Iowa Geol. Survey, Vol. XIII, pp. 185-253, 1903.

.........., Geol. of Benton County: Iowa Geol. Survey, Vol. XV, pp. 125-225, 1905.

Schuchert, Charles, A Synopsis of American Fossil Brachiopoda:" U. S. G. S. Bull. 87,1847

Shimer, H. W., Spiriferoids of the Lake Minnewanka Section, Alberta: Geol. Soc. Am., Bull. 24, pp. 333-340, 1913.

..........., Upper Paleozoic Faunas of the Lake Minnewanka Section, Near Banff, Alberta: Bull. 42, Contrib. to Can. Paleo., Geol. Ser. 45, pp. 1-89, 1926.

Springer, Frank, Crinoidea Flexibilia, Smiths. Inst. Pub. 2501, 1920.

..........., Unusual forms of Fossil Crinoids: Proc. U. S. Nat. Mus., Vol. 67, Art. 9; Washington, 1926.

S.t. John, Orestes, and Worthen, A. H.; Descriptions of Fossil Fishes: Illinois Geok. Survey, Vol. 6, p. 247, 1875.

..........., Descriptions of Fossil Vertebrates: Illinois Geol. Survey, Vol. -7, p. $57,1883$.

St. Clair, Stuart, and Weller, Stuart, Geology of Ste. Genevieve County, Missouri : Missouri Bur. of Geol. and Mines, 1928.

Stookey, S. W., Geol. of Iowa County: Iowa Geol. Survey, Vol. XX, pp. 151-186, 1910.

.........., Geol. of Poweshiek County: Iowa Geol. Survey, Vol. XX, pp. 237-269, 1.910.

Udden, J. A., Geol. of Muscatine County: Iowa Geol. Survey, Vol. IX, pp. 247-388, 1899.

.........., Geol. of Louisa County: Iowa Geol. Survey, Vol. XI, pp. 53-126, 1901.

$\ldots \ldots \ldots \ldots$, The Sweetland Creek Beds: Jour. Geol., Vol. 7, pp. 65-78, 1899.

Ulrich, E. O., The Chattanoogan Series with Special Reference to the Ohio Shale Problem: Am. Jour. Sci., Ser. 4, Vol. 34, p. 157, 1912.

.........., Revision of the Paleozoic Systems in North America: Bull. Geol. Soc. Am., Vol. 22, p. 281, 1911.

Van Tuyl, Francis M., The Stratigraphy of the Mississippian Formations of Iowa: Iowa Geol. Survey, Vol. XXX, 1928.

Wachsmuth, Charles, and Springer, Frank, Crinoidea Camerata: Mem. Mus. Comp. Zool. Harvard, Vol. 21, 1897.

Warren, P. S., Banff Area, Alberta: Memoir 153, No. 134, Geol. Ser. Canada Geol. Survey, 1927.

.........., A Kinderhook Fauna from Nordegg, Alberta: Amer. Jour. Sci., 5th Ser, Vol. 10, p. 448, 1925. 
Weller, Stuart, Bibliographic Index of North American Carboniferous Invertebrates: U. S. Geol. Surv. Bull. 153, 1898.

..........., Fossil Fauna of the Kinderhook Beds of Burlington: Iowa Geol. Survey, Vol. X, pp. 59.-79, 1900.

.........., Kinderhook Faunal Studies, No. 2, The Fauna of the Chonopectus Sandstone at Burlington, Iowa: Trans. St. Louis Acad. Sci., Vol. 10, pp. $57-129,1900$.

.........., Kinderhook Faunal Studies No. 3, The Faunas of Bed 37 at Burlington, Iowa: Trans. St. Louis Acad. of Sci,, Vol. 11, pp. 147-214, 1901.

.........., A Circum-insular Paleozoic Fauna: Jour. Geol.; Vol. 3, p. 903, 1895.

.........., The Northern and Southern Kinderhook Faunas: Jour. Geol., Vol. 13, p. $617,1905$.

.........., Correlation of the Kinderhook Formations of Southwestern Missouri : Jour. Geol., Vol. 9, .p. 130, 1901.

.........., Kinderhook Faunal Studies No. 4, The Fauna of the Glen Park Limestone: Trans. of St. Louis Acad. of Sci., Vol. 16, pp. 435-471, 1906. ...., Kinderhook Faunal Studies No. 5, The Fauna of the Fern Glen Formation: Geol. Soc. Am. Bull., Vol. 30, p. 285, 1909.

.........., Classification of the Mississippian Series: Jour. Geol. Vol. 6, p. 303, 1898.

........... Correlation of the Middle and Upper Devonian and Mississippian Faunas. of North America: Jour. Geol., Vol. 17, pp. 257-285, 1909.

.......... Internal Characters of Some Mississippian Rhynchonelliform Shells: Geol. Soc. Am. Bull. 21, p. 497, 1910.

........... The Genera of the Mississippian Loop-bearing Brachiopoda:- Jourof Geol., Vol. 19, p. 439, 1911.

........., Mississippian Brachiopoda: Mon. 1, Illinois Geol. Survey, 1911.

White, C. A., Descriptions of Carboniferous Fossils: Boston Soc. Nat. Hist., Vol. 9,1862 .

........... Report on the Geology of Iowa: Geological Survey of the State of Iowa, Vol. 1, p. $218,1870$.

Wilder, F. A., Geology of Webster County : Iowa Geol. Survey, Vol. XII, pp. 63-235, 1902.

Williams, I. A., Geology of Franklin County: Iowa Geol. Survey, Vol. XVI, pp. 453-507, 1906.

Williams, H. S., Correlation Papers on the Devonian and Carboniferous: U. S. G. S. Bull. 80, 1891. 

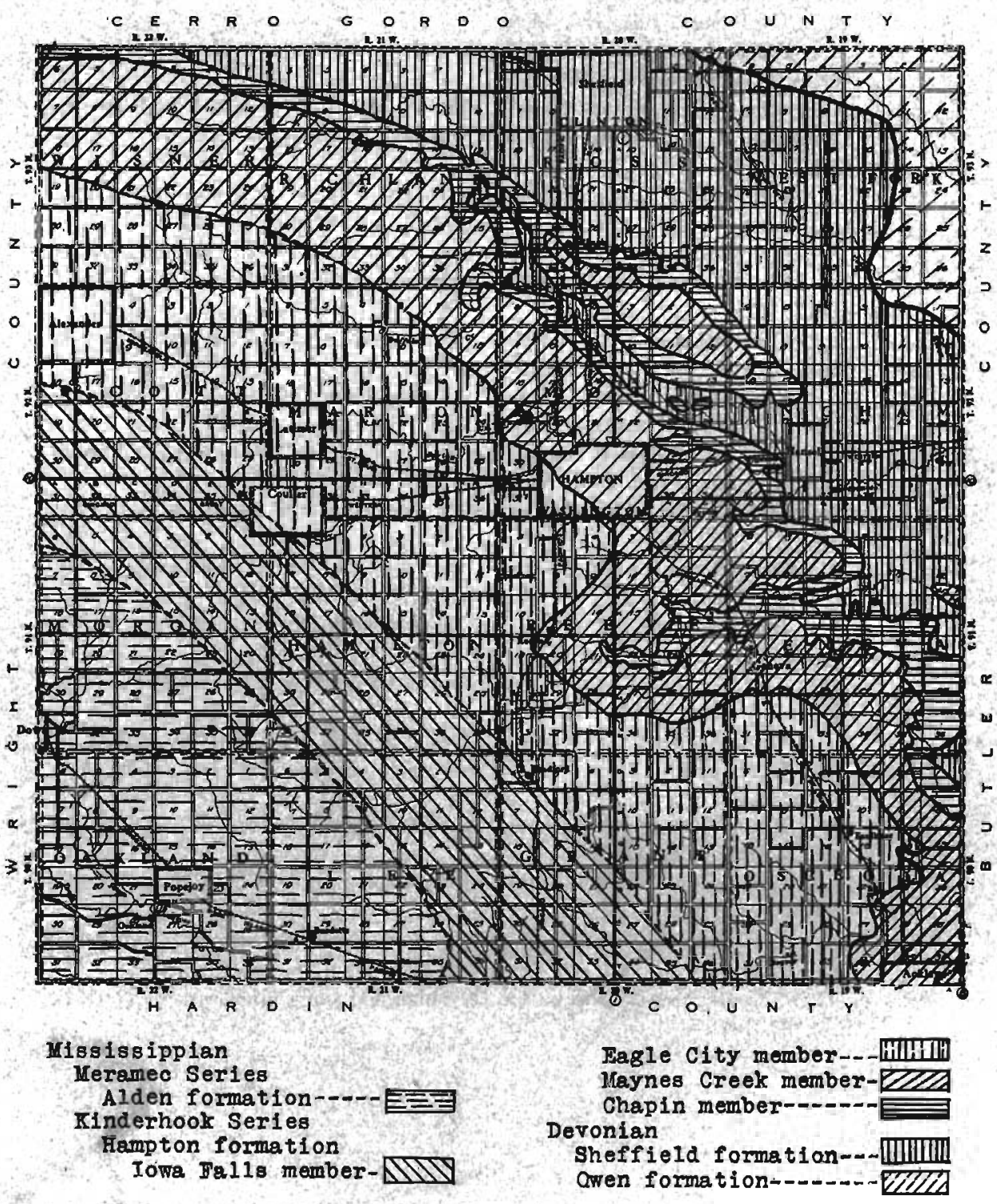

FIg. 64.-Areal geology map of Franklin county. 


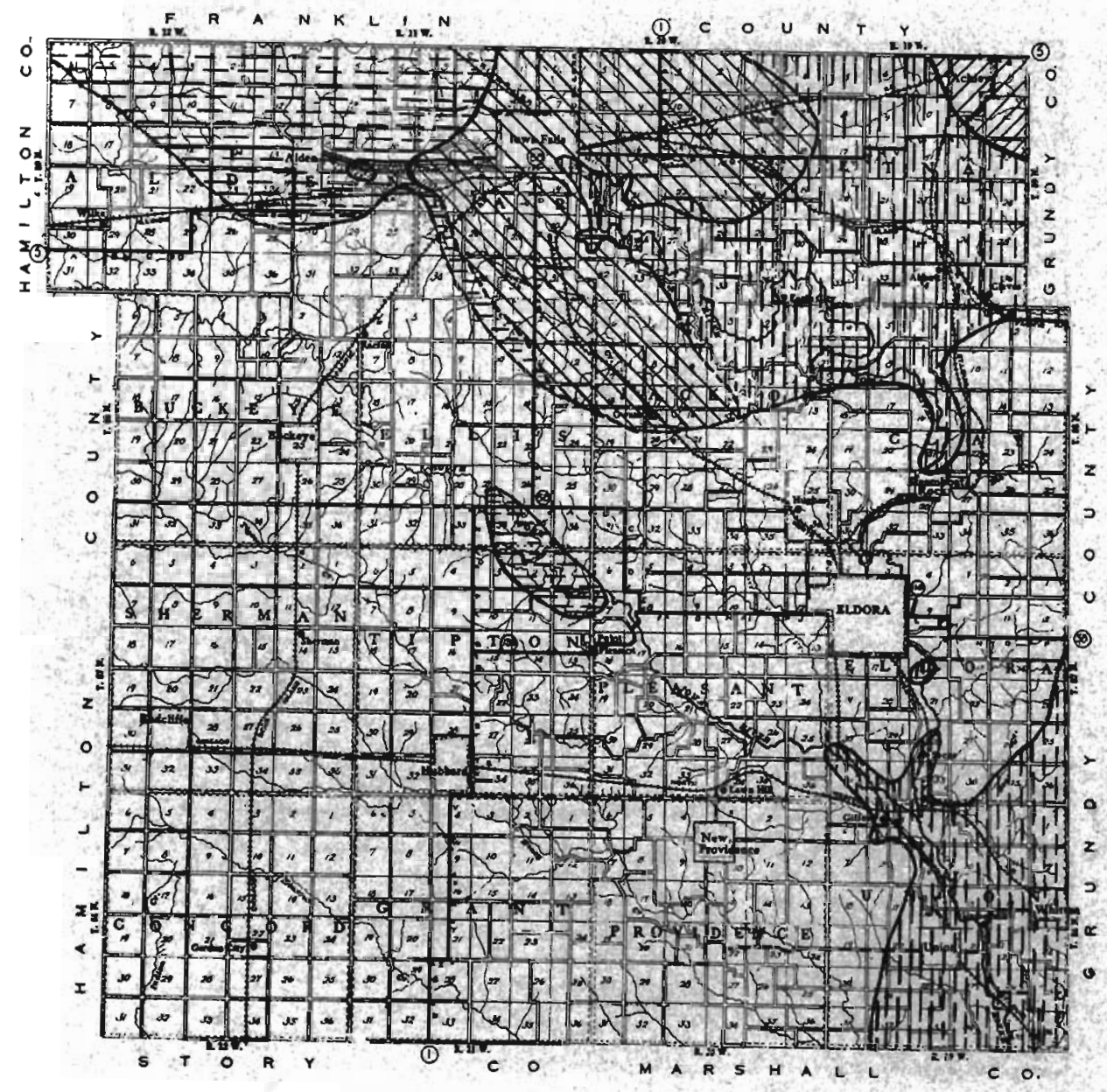

Pennsylvanian

Des Moines Series-..- $\square$

Kiseissippien

Meramec Sertes

St. Louis Formation-

Alden Formation-.--

\author{
Kinderhook series \\ Hampton Jormation \\ Iowa Falls member-.- \\ Eagle City member-- IIILIL \\ Maynes Creek member- DIIIZ.
}

Frg. 65.-Areal geology map of Hardin county. 


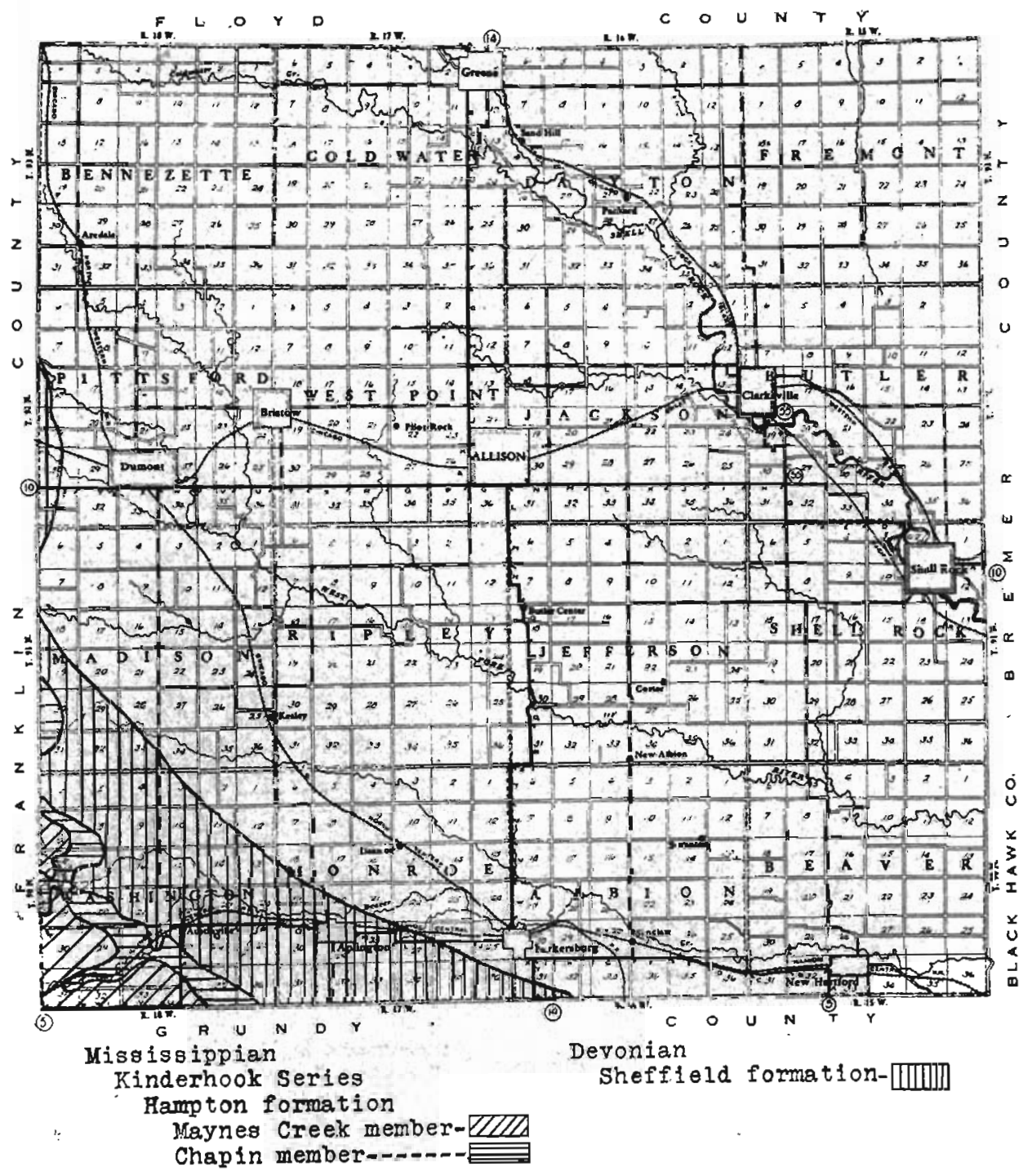

FrG. 66.-Areal geology map of Butler county. 


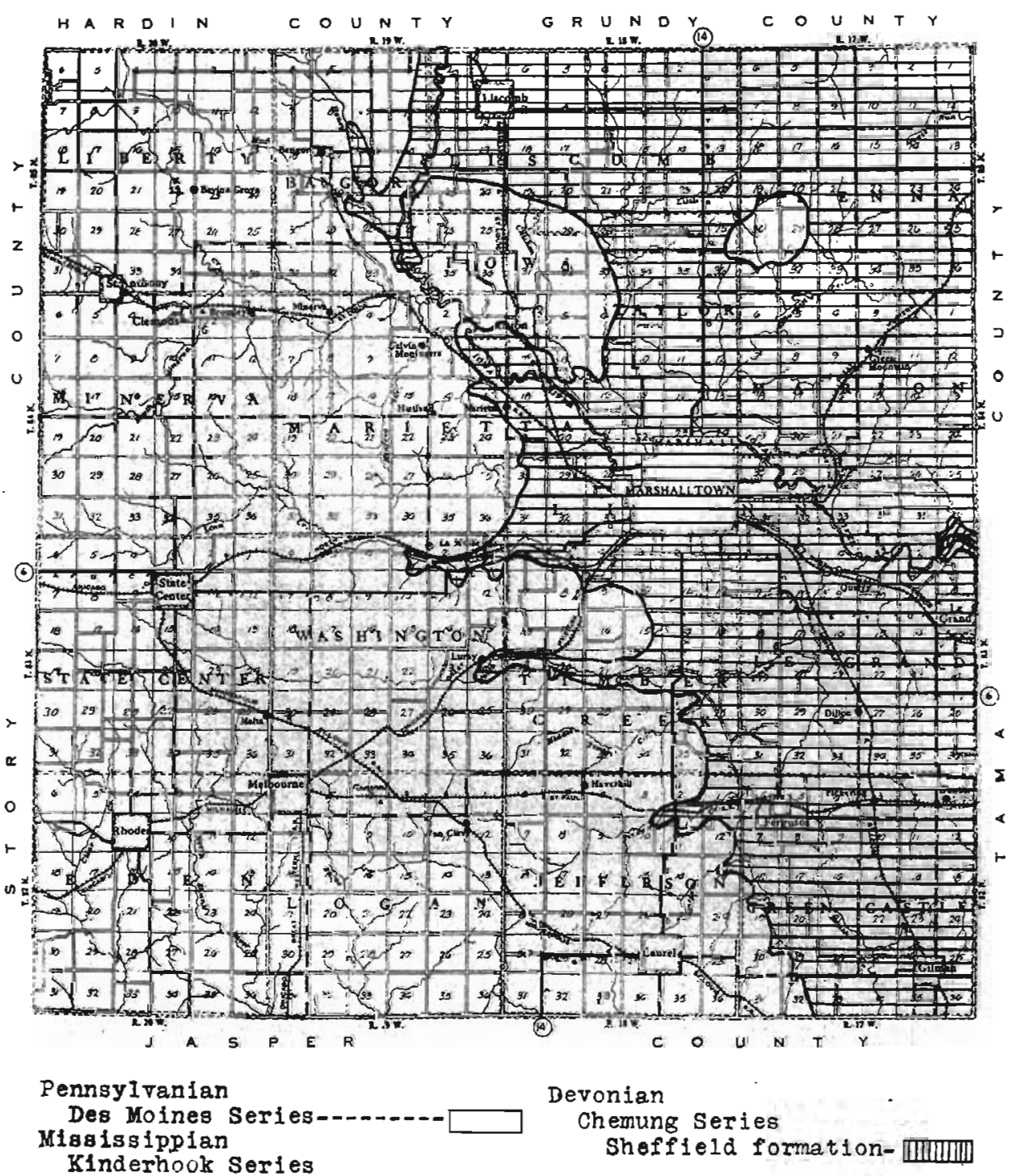

Rerpton sories

English River formation-

Frg. 67.-Areal geology nap of Marshall county. 


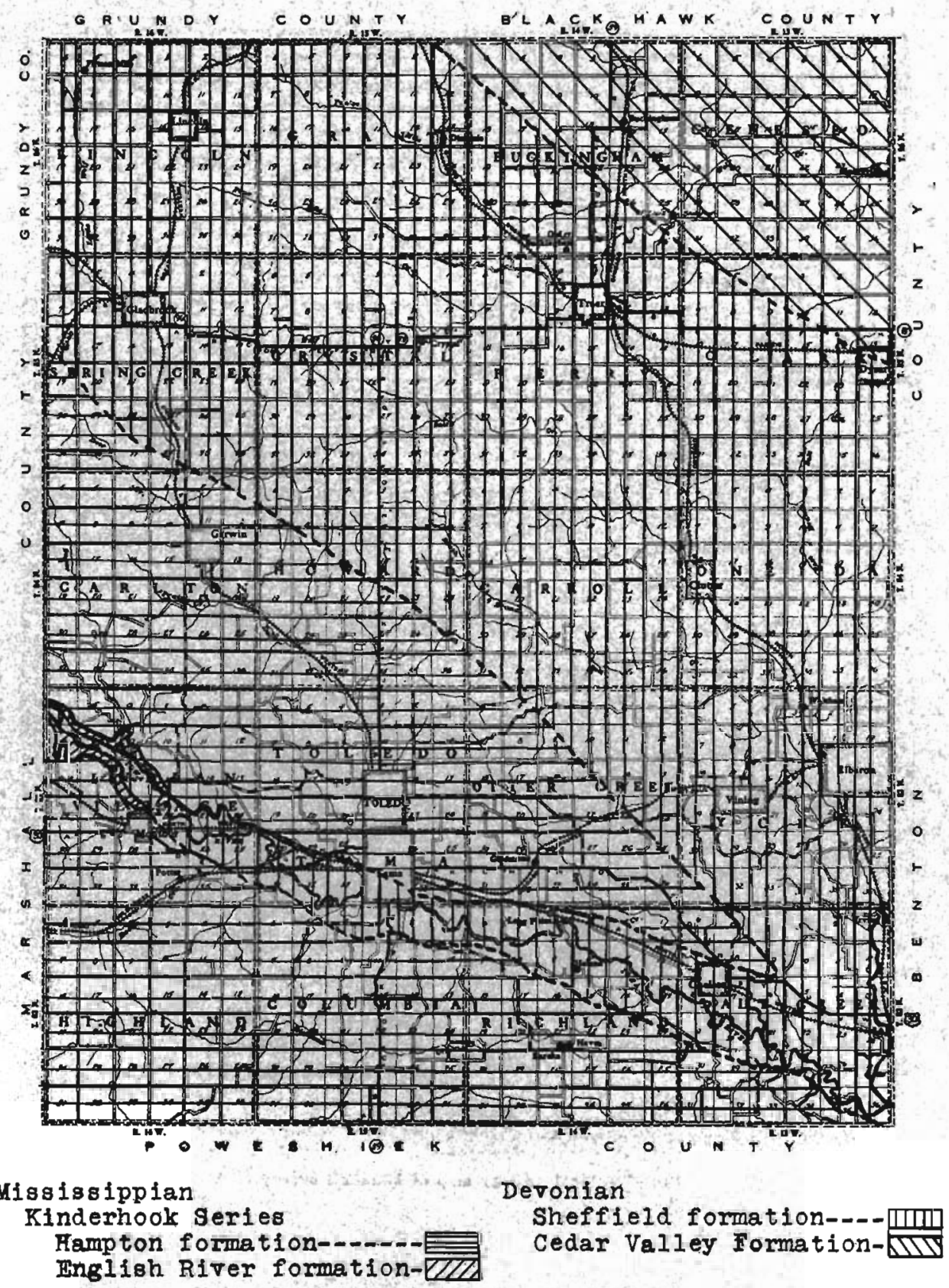

Fic. 68-Areal geology map of Tama county. 


\section{INDEX}

Ackley, Eagle City beds near, 405; fossils from, 407; section near, 433; strata near, 403

Aclisina, 381

Acondylacanthus gracilis, 358

Agelacrinus legrandensis, 427

Agonites opimus, 363,365

Alden, beds near, 418

Alden limestone, age, 387 ; relation to Hampton formation, 387; to Iowa Falls, 416; to Gilmore City beds, 416 ; to Kinderhook, 417; to Iowa Falls member, 418; section of, 434

Amana, Sheffield formation at, 377; Wassonville at, 377

Ambocoelia, 416

Amplexus, 393

Aorocrinus, 398, 400; immaturus, 427, 428; parvibasis, 428 ; radiatus, 428

Archaeocidaris legrandensis, 426,428

Arey, M. F, cited, 434; work on Kinderhook, 342

Asteroptychius vetustus, 358

Athyris corpulenta, 363,365 ; crassicardinalis, $371,394,400,416,425$ 427,429

Audubon well, strata in, 404

Aviculopecten, $358,380,408,414,425$ caroli, 363

\section{B}

Bain, H. F., eited, 366,434 ; work on Kinderhook, 342

Bassler, R. S., cited, 434

Batocrinus macbridei, 428; poculum, 428

Beaman, LeGrand beds near, 429

Beane, B. H., help given by, 350

Bellerophon, 401, 414 ; bilabiatus, 362 , 363,365 ; blairi, $363,365,381,382$, $392,400,414,428,429$; panneus, 362 , 363,365 ; vinculata, 365

Beyer, S. W., cited, 434; work on Kinderhook, 342

Brachythyris, 399, 400, 403; chouteauensis, 394, 399, 400, 427; peculiaris; $380,381,425$
Bridge, Josiah, cited, 434

Bryozoa, 415

Bucanopsis, $381,382,401$; deflectus, 365 ; perelegans, $370,381,382$

Burlington, English River beds near, 359, 361; fossils from, 358; Maple Mill beds near, 356; North Hill member at, 366; section at, 382; Wassonville member near, 371

Burlington formation, age, 348; named by Hall, 340 ; relations, 348 ; to Wassonville member, 379

Butler county, geological map of, 440 ; Hampton beds in, 384

Butlerville, fossils near, 425

Butts, Charles, cited, 435

\section{C}

Cactocrinus, $373,398,400,407,415$, 429; arnoldi, 427, 428; zone of LeGrand beds, 424; fossils in, 428; relation to Maynes Creek beds, 430; ornatissimus, 428; nodobrachiatus, 428

Calvin, Samuel, cited, 420,435 ; fossils collected by, 357 ; work on Kinderhook, 342

Camarophorella lenticularis, 370,399 , 400,402

Camarotoechia, 410,416 ; chouteauensis, $380,392,393,398,400,402,407$, $408,412,426,427,429,430,433$; zone of LeGrand beds, 422 ; fossils in, 429 ; relation to Eagle City beds, 431 ; subglobosa, $410,412,414,415,434$; zone of Eagle City beds, 409; fossils in, 410 ; section, 434 ; tuta, 380,401 , $402,416,425,426$

Capulus, 409; paralius, $392,399,400$, $402,408,428$; piso, 428 ; vomerium, 399

"Carboniferous," name for Mississippian system, 339

Cardiopsis radiata, 380,381

Cedar Valley limestone, age, 344 ; relations, 344

Centronelloidea rowleyi, 416 ; zone of Iowa Falls beds, 415 
Chaetetes, 408

Chapin, beds named from, 387; fossils from, 398; Maynes Creek beds near, 396; section in quarry near, 431

Chapin member, age, 347; character, 391; correlations, 394; Cyathaxonia arcuatus zone, 392; distribution, 389; in Franklin county, 387; in Marshall county, 389; in Tama county, 389; named by Van Tuyl, 344; near Hampton, 391; near LeGrand, 389; origin of name, 387 ; relations, 347 ; to Chouteau, 395; to Maynes Creek beds, 388, 394, 396, 403; to North .Hill member, 371, 394; to Schellwienella zone, 430; to Sheffield formation, 387, 394; sections, 431; stratigraphy, 394; Streptorhynchus tenuicostatum zone, 391; thickness, 391; zones, 391

Chapin quarry, beds in, 387, 389, 392, 431

Chattanooga shale, relations to. Sweetland Creek beds, 355; transitional character, 351

Chemung fauna, abundance, 351 ; shales, age, 352 ; relations to Sheffield beds, 385

Chert bands in Wassonville member, 373; in Wassonville-Maynes Creek, fauna in, 379,400

Chester series in Iowa, 339

Chonetes, 381, 398, 403; burlingtonensis, 408, 425; glenparkensis, 380, 398, 400; illinoisensis, $362,380,398,401$, 425; logani, $364,371,380,381,393$, 398, 401, 408, 425; multicostata, 380, $382,393,401,426,433$; zone of Maynes Creek member, 400; section, 431; gregarius zone, character, 368; distribution, 374; fauna, 370

Chonopectus fischeri, 362; zone, 363, 364

Chouteau fauna, relation to that of North Hill member, 370

Chouteau limestone, age, 340 ; at Newark, Missouri, relation to Eagle City member, 412; fauna, 382; relations, 340 ; to Chapin nember; 395; to
Hampton, 373; to Maynes Creek member, 404

Cladodus alternatus, 358 ; exiguus, 358

Cliothyridina, 380, 381, 399, 427; incrassata, 426; tenuilineata, 425

Coelacanthus welleri, 358

Columbus Junction, English River beds near, 360

Composita corpulenta, 362; opposita, 425

Conglomerate of English River material, 364

Conocardium, 399, 410, 415, 433

Conrad, LeGrand beds near, 429

Conularia, 358, 399, 430

Cooper, C. L., cited, 435 ; help given by, 350

Cranaena, 427, 430; occidentalis, 380 , 393, 398, 399

Crinoids at LeGrand, occurrence, 420

Ctenacanthus sculptus, 358 ; speciosus, 358

Cyathaxonia arcuatus, $393,426,427$, 431; zone of Chapin member, 392; fauna, 393

Cyathophyllum, 409, 410, 415

Cypricardinia sulcifera, 381, 399

Cyrtina, 399

Cyrtoceras unicorne, 365

Cystodictya, 393, 398, 399, 401, 402

\section{D}

Darton, N. H., cited, 435

Daytonville, section near, 377; Wassonville beds near, 372

Decadocrinus decrepitus, 429; hammondi, 429; longicirrifer, 429; maccabei, 428

Dentalium grandaevum, $362,363,365$, 381,402

Des Moines county, English River beds in, 359; North Hill beds in, 367; section in, 382; Wassonville beds in, 371

De Verneuil, M., cited, 339

"Devils Anvil", fossils at, 425, 429

Devonian, relation to Kinderhook faunas, 352

Dichocrinus, 427; cinctus, 428; delicatus, 426,428 ; inornatus, 428 
Dictyophyton, 368

Dielasma, $388,398,414,416,425$; burlingtonensis, 398; chouteauensis, 380, $398,408,427$

Dip of strata in Iowa, 339

\section{'E}

Eagle City, beds near, 405 ; fossils from, 408; section near, 433

Eagle City fauna, relation to that of Osage formations, 412 .

Eagle City member, age, 348; Camaratoechia subglobosa zone, 409 ; character, 405; correlation, 411; distribution, 404; life zones, 407; in Ellsworth stone quarry, 410; in Franklin county, 404; in Grundy county, 411; in Hardin county, 405, 407, 411; in Marshall county, 407, 411; in Tama county, 407; named by Van Tuyl, 344; near Ackley, 405; near Eldora, 405, 409; near Gifford, 408; near Iowa Falls, 405, 409; origin of name, 404; part of Hampton formation, 412 ; relations, 348 ; to Camarotoechia zone, 431 ; to Chouteau at Newark, Missouri, 412; to Iowa Falls dolomite, 411; to LeGrand beds, 422 , 430; to Maynes Creek beds, 403, 411, 431; Rhipidomella .burlingtonensis zone, 407; section, 433; Spirifer biplicoides zone, 407; Straparollus obtusus zone, 409; stratigraphy, 411; thickness, 405

Edmondia aequimarginalis, 362 ; burlingtonensis, 362,363 ; jejunus, 363 , 380,381 ; quadrata, 362,363

Eldora, Eagle City beds near, 405, 409

Ellsworth stone quarry, Eagle City beds in, 410; fossils from, 414; lithographic limestone in, 410

Elymella missouriensis, 381

Encrinital group, age, 339

English River gritstone, age, 347; character, 360, 365; conglomerate of 364, 378; distribution, 359; exposures, 341 ; fauna, 361, 362, 365; in Des Moines county, 359 ; in Louisa county, 360; in 'Marshall county, 364, 378; in Tama county, 364, 378; in Wash- ington county, 360; near Burlington, 359,361 ; near Columbus Junction, 360; near Kalona, 360; near LeGrand, $360,361,364$; relations, 347 ; to Hampton formation, 374 ; to Hannibal, 365, 373; to LeGrand beds, 430 ; to Maple Mill, 357, 361; to North Hill member, 370, 374; to Wassonville, 372,375 ; thickness, 360,363

English River-Hampton unconformity, 373

Eumetria, 426; altirostris, 358, 362, 363; osagenesis, 380,399 , 408; verneuiliana, $408,410,412$

Euphemus, 365, 381, 401

Eutaxocrinus fletcheri, 427,428

\section{F}

Fauna of Chapin member, 392; Eagle City member, 407; English River beds, 361; Gilmore City beds, 416; Hampton.formation, 425; Iowa Falls member, 413; Maple Mill beds, 357; Maynes Creek member, 397; North Hill member, 370; Sweetland Creek beds, 354; Wassonville member, 379;See also various zones

Fenestella, 373, 394, 398-400, 402, 408

Fillman, Louise, help given by, 349

Fish teeth in LeGrand beds, 428, 429; in Maple Mill shale, 358

Fish tooth conglomerate in Sweetland Creek beds, 355

Fort Dodge, strata in well at, 403

Fort Madison, Kinderhook beds near, 340

Franklin county, Chapin beds in, 387; Eagle City beds in, 404; geological map of, 438; Hampton beds in, 384; Maynes Creek beds in, 396; North Hill beds in, 371 ; sections in, 431

\section{G}

Gastropod, 354

Gifford, Eagle City beds near, 408

Gilmore City, beds near, 416

Gilmore City limestone, age, 416; age of fauna, 416; relation to Alden limestone, 416; to Kinderhook, 417; to Madison limestone, 417 
Girty, G. H., cited, 435

Glossites elliptica, 363

Gomphoceras, 358

Goniatites, 381

Goniocrinus sculptilis, 428

Goniophora jennae, 362

Grammysia amygdalinus, $362,363,380$, 392; plena, 362

Grassy Creek shale, transitional character, 351

Griffithides, 399, 428

Grundy county, Eagle city beds in, 411; Hampton beds in, 384; LeGrand beds in, 422, 429

Gurley, Wm. F. E., cited, 435

Gyroceras, 381, 382

\section{H}

Hackberry shale, age, 346; relations, 346

Hall, James, cited, 435; work of, 340 ; on Kinderhook, 342

Hampton, beds named from, 387 ; Chapin beds near, 391; Maynes Creek beds near, 396 , 402; sections near, 431

Hampton formation, age, 347; at LeGrand, 419 ; divisions, 344,387 ; Eagle City beds part of, 412 ; exposures, 351 ; fauna, 370,401 ; in Butler county, 384; in Franklin county, 384; in Grundy county, 384; in Hardin county, 384; in Marshall county, 384; in southeastern Iowa, 366; members, 366; name proposed, 344, 387; relations, 347 ; to Alden limestone, 387; to Chouteau, 373; to English River, 374; to Iowa Falls member, 419; to Maple Mill, 374; to Sheffield beds, 374, 387; unconformity with English River, 373

Hannibal formation, conditions during formation, 351 ; relations, 340,359 , 365; to English River, 373

Hardin county, Eagle City beds in, 405, 407, 411; geological map of, 439; Hampton beds in, 384; Iowa Falls beds in, 413

Holopea conica, 381 ; subconica, 416
Humboldt, beds near, 416

Hustedia circularis, 408, 412

\section{I}

Igoceras subplicatum, 409, 414, 428; undata, 399

Iowa county, Wassonville beds in, 372 , 377

Iowa Falls, beds near, 413, 433; Eagle City beds near, 405, 409, 433; fossils near, 414

Iowa Falls member, age, 348; Centroneloidea rowleyi zone, 415; character, 413; distribution, 413; fauna, 409, 413, 419; in Hardin county, 413; Loxonema zone, 414 ; named by Van Tuyl, 344,412 ; relations, 348 ; to Alden limestone, 417, 418; to Eagle City member, 411; to Hampton formation, 419; sections, 433, 434; Spirifer platynotus zone, 414 ; stratigraphy, 416; thickness, 413

J

Juniper Hill shale, age, 345; relations, 345

\section{K}

Kalona, English River beds near, 360 ; fossils from, 362; Maple Mill beds near, 356 ; section at clay pit, 375 , 383

Keokuk limestone, age, 348 ; named by Hall, 340 ; relations, 348

Keyes, Charles R., cited, 435; work on Kinderhook, 342

Kinderhook faunas, relation to Devonian, 352

Kinderhook series in Iowa, 339; area of outcrop, 340; basal, age, 351; area, 351; fossils, 354, 358, 362; in Marshall county, 351; in north-central province, character, 384; divisions, 385 ; structure, 385 ; in southeastern Iowa province, 351 ; in Tama county, 351; Mississippian age of, 352; named by Meek and Worthen, 340; near LeGrand, 352; nomenclature, 344; relation to Alden beds, 417; to Gilmore City beds, 417 
Kindle, E. M., cited, 435

King, H., cited, 340

Krey, Frank, cited, 354, 435

L

Leda saccata, 380, 401

LeGrand, Chapin beds near, 389; crinoids in quarries at, 420; English River beds near, 360, 361, 364; Hampton formation at, 419; Kinderhook strata exposed near, 342; North Hill member at, 371 ; oölitic beds at, 422; Wassonville member at, 371

LeGrand crinoids, preservation, 420

LeGrand limestone, Cactocrinus arnoldi zone, 424; Camarotoechia chouteauensis zone, 424; character, 422; correlation, 430; distribution, 422; in Grundy courity, 422, 429; in Marshall county, 422; in Tama county, 422; Orophocrinus zone, 424; Pachylocrinus genista zone, 424 ; relation to Eagle City beds, 422, 430, 431 ; to English River formation, 430 ; to Maynes Creek beds, 431 ; to Sheffield beds, 430 ; Schellwienella planumbona zone; 422; Spiriferina solidirostris zone, 424 ; stratigraphy, 430 ; thickness, 422

Leiopteria spinulata, 363

Leptaena analoga, $370,371,373,380$, $393,398,399,407,408,412,426,427$

Leptopora typa, 393, 426, 427, 429

Lingula, 354, 355, 358; melie, 354; nuda, 354; subspatulata, 354

Liopteria subovata, 380, 399, 401

Lithographic limestone, age, 340

Louisa county, English River beds in, 360; fossils in, 362; Maple Mill beds in. 356; North $H$ ill beds in, 368; Wassonville beds in, 371

Louisiana limestone, conditions during formation, 351 ; relations, 340,359

"Lower Carboniferous", name for Mississippian system, 339

Loxonema, 381, 382, 433; zone of Iowa Falls beds, 414; section, 434

\section{M}

Macbride, T. H., cited, 435 .

Madison limestone, relation to Gilmore City beds, 417

Maple Mill shale, age, 346 ; character, 356; distribution, 355 ; exposures, 351 , 356; fauna, 357; in Louisa county, 356; in Washington county, 356; near Burlington, 356; near Kalona, 356; relations, 346, 357; to English River gritstone, 357; to Hampton formation, 374 ; to Hannibal shale, 359 ; to 'Wassonville, 373; thickness, 356; transitional character, 351

Marshall county, Chapin beds in, 389; Eagle City beds in, 407, 411; English River beds in, 364, 378; geological map of, 441; Hampton beds in, 384; North Hill beds in, 371; Kinderhook in, 351; LeGrand beds in, 422

Maynes Creek member, age, 347 ; character, 397; Chonetes multicostatus zone, 400; definition, 396; distribution, 396; equivalent to Wassonville, 371; fauna, 397; in chert bands, 400; relation to that of Eagle City beds, 411, in Franklin county, 396; named by Van Tuyl, 344, 395; Productus sedaliensis zone, 397 ; relations, 347 ; to Chapin member, $388,394,396,403$; to Chouteau of Missouri, 404; to Eagle City beds, 403; to LeGrand beds, 431; to Pachylocrinus zone, 426, to Wassonville beds, 377 ; section of, 431 , Spirifer striatiformis zone, 402 ; stratigraphy, 403 ; thickness, 397

Meek, F. B., cited, 435; and Worthen, cited, 420; work of, 340 ; on Kinderhook, 342

Meekospira, 401

Megistocrinus nobilis, 427,428

Meramec series in Iowa, 339

Mesodmodus explanatus, 358

Methods, field, in study of Kinderhook, 343

Miller, S. A., cited, 435

Miller and Gurley, cited, 420

Mississippian age of Kinderhook beds, 352 
Mississippian system in Iowa, 339; character, 339 ; chert in, 339; classification, 339, 341; dip, 339; marine origin, 339 ; outcrop, 339

Moore, R: C., cited, 358, 365, 370, 37I, 436; work on Kindērhook, 340, 342

Morning Sun, North Hill member at, 368

Mountain Limestone of Europe, age, 339

Murchisonia, 381; quadricincta, 362

Muscatine, Sweetland Creek beds near, 353

Muscatine county, Sweetland Creek beds in, 352

Myalina, 401

Mytilarca fibristriata, 363; occidentalis, 362,363

\section{$\mathbf{N}$}

Naticopsis depressa, 362

Newark, Missouri, Chouteau at, 370; fauna at, 382

Nomenclature of Kinderhook series, 344

North-central Iowa province, area, 342; character of Kinderhook of, 384

North Hill member, age, 347 ; at Burlington, 366; at LeGrand, 371; at Morning Sun, 368; character, 368; distribution, 366; exposures, 366; fauna, 370 ; relations to that of Chouteau, 370; to that of English river, 370; in Franklin county, 371; in Louisa county, 368; in Marshall county, 371; name proposed, 344; relations, 347; to Chapin beds, 371, 394; to Chouteau of Missouri, 371; to English River formation, 369, 374; to Schellwienella zone, 430 ; to W'assonville member, $369,371,372$; stratigraphy, 369; thickness, 368; zones, 368

Norton, W. H., cited, 403, 436

Nucleospira barrisi, 380, 381, 394, 399, 401,402

Nucula glenparkensis, 380, 401; iowensis, 380,401

Nuttall, T., cited, 339

\section{O}

Oölitic beds at Gilmore City, 416; at LeGrand, 422

Orbiculoidea, 258; capax, 362; varsoviensis, 398

Orodus daedalus, 358 ; decussatus, 358

Orophocrinus conicus, 414, 427-430; zone of LeGrand beds, 424; fossils in, 426; relation to Maynes Creek beds, 430; to Wassonville beds, 430; fusiformis, 414, 427, 428; stelliformis, 414,427

Orthoceras, $382,406,425,429$; indianensis, 362, 363, 381, 402, 409, 415, 419; whitei, $362,363,365$

Orthonychia, 401, 408, 416

Orthotetes, 401, 416

Osage series in Iowa, 339; relation of Eagle City fauna to, 412

Owen, D. D., cited, 339, 340

Owen limestone, age, 346; relations, 346

$\mathbf{P}$

Pachylocrinus elegantulus, 428; genista, 426, 428; zone of LeGrand beds, 424; fossils in, 425; relation to Maynes Creek member, 426, 430; to Wassonville cherts, 426, 430; globosus, 428; legrandensis, 428; scopae, 428; spartarius, 428

Palaeoneilo barrisi, 380, 381; zone, character, 369; distribution, 374; fauna, 370

Palaeopalaemon newberryi, 358

Paryphorhynchus elongatum, 392, 400; striatocostatum, 363,364, 370; zone, character, 369; distribution, 374; fauna, 370; transversum, 362

Pernopecten, 380; cooperensis, 380, 381 Phanerotinus paradoxus, 365, 381, 382 Phillipsia, 401

Physonemus depressus, 358; proclivus, 358

Plant remains in Maple Mill shale, 358; in Sweetland Creek beds, 355

Platyceras erectoides, 426

Platycrinus, $373,380,393,398,400,402$, $409,414,427,429$; agassizi, 428; symmetricus, 426,428 
Platyschisma, 358; barrisi, 362, 363, 365 ; depressa, $362,363,365,381$; missouriensis, $363,365,415$

Pleurotomaria, 381

Porcellia, 358, 381; obliquinoda, 363

Posidonomya, 399; ambigua, 362, 365

Pristicladodus armatus, 358 ; springeri, 358

Pristodus ? acuminatus, 358

Productella, 358, 425; concentrica, 362, $371,380,381,392,393,398,401,402$, 426, 427, 430; numularis, 362

Productus, $380,398,399,408,425,426$, 429 ; arcuatus, $370,371,380,381,382$, 393, 398, 426, 427; blairi, 408, 412; curtirostris, 362; mesicostalis, 362, 365 ; ovatus, $358,380,392,393,398$, 401, 408, 425, 426, 429; zone of Chapin member, 391 ; fauna, 392; sedaliensis, $398,399,403,414,419$; zothe of Maynes Creek member, 397; sections, 431

Proetus, 381, 399-403, 407, 408, 428

Prospect Hill, section at, 382

Psephodus reticulatus, 358

Pterinites whitei, 362, 363

Pterinopecten nodocostatus, 425

Ptychodesma, 402

Ptyctodus calceolus, 354

\section{Q}

Quarries at LeGrand, crinoids in, 420

\section{$\mathbf{R}$}

Reticularia, 355, 434; cooperensis, 370, $380,381,399,403,408,409$; pseudolineata, 414

Rhipidomella, 358, 430; burlingtonensis, $370,407,414,427$; zone of Eagle City beds, 407; section, 433; dubia, 426, 429; tenuicostata, 393, 398, 399, $400,408,414,419,425$; thiemei, 380 , 381,426

Rhodocrinus, 373, 380; kirbyi, 428; nanus, 428; watersianus, 426-428

Rhombopora, 373, 408

Rhynchodus cf. excavatus, 354

Rhynchopora pustulosa, $370,380,426$

Rhynchotreta, 430
Roth, Robert A., cited, 436

Rowley, R. R., cited, 420, 436

\section{S}

St. Clair, Stuart, cited, 436

St. John, Orestes, cited, 436

St. Louis limestone, age, 349; named by King, 340; relations, 349

Ste. Genevieve formation, age, 349; relations, 349

Sardeson, F. W., cited, 436

Savage, T. E., cited, 436; work on Kinderhook, 342

Saverton shale, conditions during formation, 351

Schellwienella, 380, 381, 392, 393, 401, 414, 425, 426, 430; crenulicostata, 380, $381,398,430$; inaequalis, 362,364 , $380,381,403,427$; inflata, 371, 380, $393,398,401,408,412,425,427$; planumbona, $371,380,381,408,425$, $427,429,430$; zone, character, 369 ; distribution, 374;-'fauna, 371, 425; of LeGrand beds, 422; relation to Chapin member, 430 ; to North Hill member, 430

Schizoblastus, 429; roemeri, 393, 431

Schizodus, 381,410 ; iowensis, 362,363 ; sedaliensis, 380,425 ;

Schizophoria, 355, 358, 362, 408, 430; chouteauensis, $380,381,393,398-400$, 403; sedaliensis, 427; subelliptica, 380; swallovi, 362

Schoenaster legrandensis, 426

Schuchert, Charles, cited, 436

Sheffield formation, age, 346; at Amana, 377 ; relations, 346 ; to Chapin member, 387, 394; to Chemung, 385; to Hampton formation, 374, 387; to LeGrand beds, 430

Shell Rock formation, age, 344; relations, 344

Shimer, H. W., cited, 436

Solenocaris strigata, 354

Southeastern Iowa province, area, 341; Kinderhook in, 351

Spathiocaris emersoni, 354

Spergen formation, age, 348 ; relations, 348

Sphenotus, 381 
Spirifer, 380, 399, 400, 402, 409, 414, 416 , 427; biplicatus, 363,364 ; biplicoides, 380, 381, 398, 399, 400, 402, 408, 414, 419, 427; zone of Eagle City, beds, 407; section, 433 ; calvini, 408, 412, 427; forbesi, 393; gregeri, 399 , 427; latior, 408, 412; legrandensis, 380, 393, 398-401, 427; louisianensis, $380,381,399,414,419,426,427$; maplensis, 363; marshallensis, 399; missouriensis, 393, 399, 400, 408, 409, $412,414,419$, 426; platynotus, 370 , $371,380-382,393,398,403,407,409$, $412,414,415,419,425-427,429,433$, 434; zone of Iowa Falls beds, 414; section, 434; striatiformis, 398, 400, 403, 409; zone of Maynes Creek member, 402 ; subrotundus, 362, 363, 365

Spiriferina, 380, 398, 402, 408, 415, 427; solidirostris, $380,393,398-403,408$, $412,416,427,429,430$; zone of LeGrand beds, 424; fossils in, 429; relation to Maynes Creek beds, 430; subtexta, 380, 398, 400, 402, 408

Springer, Frank, cited, 436; fossils collected by, 358; work on Kinderhook, 342

Stookey, S. W., cited, 436; work on Kinderhook, 342

Straparollus, 382, 408; ammon, 363; angularis, 363,365 ; lens, 381 ; macromphalus, $365,381,382,401,402$; missouriensis, 429 ; obtusus, 371,394 , $409,410,415,419,425,430,433$; zone of Eagle City member, 409; section, 433

Streptorhynchus, 380,381 , 427; tenuicostatum, 393, 408, 410, 412, 415, 419; zone of Chapin member, 391; fauna, 392; section, 431

Stromatopora, 410

Strophostylus bivolve, 362, 363, 365, $381,382,401,407,428$

"Sub-Carboniferous", divisions, 340; names for, 339

Swallow, G. C., work of, 340

Sweetland Creek beds, age, 346; character, 355; distribution and thickness, 352; exposures, 353 ; fauna, 354; in
Muscatine county, 352; near Muscatine, 353 ; relations, 346,354 ; to Chattanooga shale, 355 ; transitional character, 351

Synthetodus, 354

Syringopora, 393, 410

Syringothyris, 425; extenuatus, 362 , 364 ; halli, 380, 381; newarkensis, 392 , $393,399,400$

\section{T}

Tama county, Chapin beds in, 389; Eagle City beds in, 407; English river beds in, 364, 378; geological map of, 442; Kinderhook in, 351; I.eGrand beds in, 422

Taxocrinus intermedius, 428

Tester, A. C., help given by, 349

Thomas, A. O., help given by, 349

Tigeria, 380, 401, 402

Trowbridge, A. C., help given by, 349

\section{$\mathbf{U}$}

Udden, J. A., cited, 354, 436; fossils collected by, 357; work on Kinderhook, 342

Ulrich, E. O., cited, 436

Upper Burlington at Wassonville Mill, 379

\section{V}

Van Tuyl, F. M., cited, 352, 358, 362, $365,370,385,387,393,395,398,401$, $404,412,415,433,436$; work on Kinderhook, 340, 342

Vermicular sandstone, age, 340 ; relations, 340

\section{W}

Wachsmuth, Charles, cited, 436; work on Kinderhook, 342; and Springer, cited, 420

Warren, P. S., cited, 436

Warsaw formation, age, 348 ; relations, 348

Warthia, 381

Washington county, English River beds in, 360; Maple Mill beds in, 356; sections in, 383; Wassonville beds in, 371 
Wassonville chert bands, 372; fauna, 379; relation to Pachylocrinus zone, 426

Wassonville dolomite member, age, 347; character, 372 ; distribution, 371 ; equivalent to Maynes Creek, 371; fauna, age, 382; fish fauna, 375; in Des Moines county, 371; in Iowa county, 372, 377; in Louisa county, 371 ; in Washington county, 371 ; near Amana, 377; near Burlington, 371; at Daytonville, 372; near LeGrand, 371; relations, 347 ; to Burlington limestone, 379; to English River member, 372, 375; to Maple Mill formation, 373; Maynes Creek member, 377; to North Hill member, 371, 372 ; sections, 375,377 ; stratigraphy, 372; thickness, 372

Wassonville-Maynes Creek fauna, 396; in chert bands, 400

Wassonville Mill, beds named from, 371 ; section at, 377,383 ; Upper Burlington at, 379
Waverly group, age, 339

Weller, Stuart, cited, 362, 365, 366, 370, 436, 437; work on Kinderhook, 340 , 342

White, C. A., cited, 437; work of, 340; on Kinderhook, 342

Whitfield, work of, 340

Wild Cat Glen, beds in, 413; fossils from, 415

Wilder, F. A., cited, 437

Williams, H. S., cited, 339, 437

Williams, I. A., cited, 437; work on Kinderhook, 342

Williams, James S., help given by, 350

Woodocrinus notatus, 429

Worthen, A. H., cited, 436; work of, 340

Worthenia, 380

\section{Z}

Zaphrentis, 399, 409, 416, 425, 426; calceola, 393; cliffordana, 380, 393, 398$402,414,427,429$; wortheni, 427 
